\title{
Implementation of Building Information Modeling (BIM) Using Hybrid Z-DEMATEL-ISM Approach
}

\author{
Ali RezaHoseini $\left(\mathbb{D},{ }^{1}\right.$ Elmira Ahmadi $\left(\mathbb{D},{ }^{1}\right.$ Pantea Saremi $\mathbb{D}^{2},{ }^{2}$ and Morteza BagherPour ${ }^{1}{ }^{1}$ \\ ${ }^{1}$ School of Industrial Engineering, Iran University of Science \& Technology, Tehran, Iran \\ ${ }^{2}$ School of Industrial Engineering, Sharif University of Technology, Tehran, Iran \\ Correspondence should be addressed to Ali RezaHoseini; ali_rezahoseini@ind.iust.ac.ir
}

Received 19 November 2020; Revised 29 December 2020; Accepted 28 January 2021; Published 16 February 2021

Academic Editor: Wen Yi

Copyright (c) 2021 Ali RezaHoseini et al. This is an open access article distributed under the Creative Commons Attribution License, which permits unrestricted use, distribution, and reproduction in any medium, provided the original work is properly cited.

\begin{abstract}
Due to the shortcomings of the traditional construction project management system, there is a feeling among those involved in this industry that new tools and approaches should be used to facilitate simple and complex operations. On the contrary, there is no integrated database for all construction sectors, and of course the relationship between these sectors is a major problem for any construction project. The technology and tool that overcomes many of these shortcomings is BIM technology. This paper seeks to identify all the challenges that hinder the successful implementation of BIM and determine important challenges based on ZDEMATEL-ISM Hybrid approaches. The DEMATEL method is used to obtain the weight of the challenges and the most influencing and influenced challenges. The ISM approach is then employed to design a hierarchical network of challenges and tries to determine the level and impact of each challenge in the planned structure. For closeness to the real-world, Z-number (an ordered pair of fuzzy numbers, where the first component controls on a fuzzy variable, and the second component is a measure of reliability for the fuzzy component) is also used to consider the expert's mental uncertainties in the final results. This research tries to examine the literature related to the subject and consider the sources and opinions of many professors and university experts based on the filled questionnaires. The findings of this paper show that "misunderstanding the BIM technology" is recognized as the most important challenge with the most weight. At the same time, "lack of governmental support" is the most influencing challenge, and "lack of interaction and teamwork" is the influenced challenge.
\end{abstract}

\section{Introduction}

The construction project manager is in charge of project management planning, cost management, time management, quality management, contract administration, safety management, risk management, and cooperation between all stakeholders on the project with owner, designers, and engineers [1]. Project management is the process of coordinating the different parts of the project to achieve the main goals of the project and the stakeholders' expectations [2]. The construction industry requires the integration of many construction activities along with redesigning many of their organizational functions and processes, teamwork, and flexibility, and it also requires a high degree of coordination, all of which can be accomplished by BIM. BIM technology can accommodate a powerful safeguard for cost control. It also reduces the risk of order and contract performance and also performs exact management. It is, furthermore, known as the most common approach for designing, constructing, and controlling the maintenance of buildings. Building Information Modeling (BIM) can be well-defined as a reliable, digital, and three-dimensional, virtual representation of the project to be built for use in design decision-making, construction scheduling and planning, cost estimation, and maintenance of construction projects. According to the BIM Handbook, BIM is a computer-aided modeling technology for the resolution of managing the information of a construction project, with special concentration on production, communication, and analysis of building 
information models [3]. The most common wrong assumption is that BIM has a single model or database which is not even close to the real applications of BIM. Although $\mathrm{BIM}$ reduces mundane jobs associated with data processing, it can never replace humans since the input data are always added to the model by a human user [4]. BIM adoption is a significant subject to a review which has gained growing attention around the globe, particularly in the developed countries over the past years [5]. According to survey results released by Davis Langdon, an AECOM Company, the full size of the global construction market had reached 4.4 trillion dollars by 2010 . The Chinese construction market has surpassed $\$ 800$ billion, showing a growth rate of $10 \%$ in the period from 2010 to 2011 . In the United States, about half of the construction agencies have been using building information modeling (BIM) or BIMrelated tools leading to a $25 \%$ rise in usage over the past two years. BIM technology will eventually lead to building information technology towards a higher level [6]. Although the UK is forceful to be a front-runner in BIM with its worldwide influential program, the Scandinavian countries have had BIM rules in place for almost a decade. France, Germany, and Spain have quickly growing programs. China, Hong Kong, and Singapore had their rules in place before the UK, along with Dubai [7]. Figure 1 gives an overview of global BIM adoption.

In the context of the global adoption of BIM, there are many published papers that have studied one particular country as a case study. Chan et al. present critical success factors for BIM in Hong Kong [9]. If the project team members do not really believe in the importance of BIM and its advantages on a construction project, the outcomes will not be acceptable [10]. (1) IT capacity, (2) technology management, (3) attitude and behavior, (4) role-taking, (5) trust, (6) communication, (7) leadership, and (8) learning and experience are mentioned as eight concepts influencing the development of BIM in a paper [11]. Another survey which has mentioned the importance of member interaction states that the challenges of using BIM on construction projects can be grouped as four challenges: (1) technological challenges which are general conflicts and issues regarding data sharing and BIM software problems, (2) operational challenges which are about project team members, (3) operations' legal challenges which refer to the lack of standards and legal definition of BIM professional responsibilities, (4) economic challenges, which sometimes hinder the construction firms from upgrading their current systems to a BIM system [12]. According to the importance of the issues discussed in the introduction, the following contributions will be considered:

(1) Identifying challenges of BIM implementation based on past studies and expert opinions and categorizing them.

(2) Practical use of Z-number to get closer to the real world. Because the opinions of the experts are accompanied by uncertainty, this uncertainty is presented in Z-number. Finally, the Z-number results are compared with the fuzzy results.
(3) Weighing the challenges and identifying the relationship between them, the influencing and influenced challenges are obtained using Z-DEMATEL.

(4) Identifying the hierarchical network model among the challenges of the Z-Number-ISM approach.

In this paper, a review of the literature on BIM and its history, definitions, and necessity for implementation is presented in Section 2. As mentioned, since the opinions of experts are associated with uncertainty, fuzzy Z-number is used to bring these opinions closer to reality. The DEMATEL method is used to calculate the weight of challenges and the influence of challenges; then, the ISM method is used to design a hierarchical network of challenges. All of these methods are explained in Section 3. It is attempted to find the challenges of implementing BIM using questionnaires, interviewing the experts, and sifting these challenges. Afterward, the relationships between these challenges are identified, and the weight of challenges, influencing and influenced challenges by DEMETEL, and a hierarchical network of challenges regarding ISM methods for a case study (Iran) are explained in Section 4. Additional explanations are provided in Section 5. Conclusion and future recommendations are mentioned in Section 6.

\section{Literature Review}

In 2006, Brucker et al. discuss BIM as a popular technology for the construction industry. BIM technology covers many aspects, such as BIM modeling, application, and management. BIM application started in the USA when United States Army Corps of Engineers (USACE) formulated a 15 year BIM Roadmap [13]. Then, in 2008, Eastman et al.'s work "Building Information Modeling (BIM) is both a technology and a process emerging" mentioned digital representation and information exchange that eases access to all relevant data is the base of BIM. Eastman et al. express BIM as a "verb to describe tools, processes, and technologies that are facilitated by digital machine-readable documentation about a building, its performance, its planning, its construction, and later its operation" [3]. A new concept has emerged as BIM levels this year. It has different noticeable levels of BIM which have different tasks to do. It is a 3D model-based source of information that BIM has at different levels. Bew and Richards identified four levels of BIM using a maturity matrix from Level 0 to Level 3. Although the concept of each of these maturity levels is slightly different, they demonstrate the same expectations with different functionalities [14]. In the same year, Yan and Demian work on benefits and barriers of BIM comprehensively. Their paper collects questionnaire data from a survey of about 70 individuals' industries that use BIM and determines benefits and barriers of it [15]. Building Information Modeling (BIM) is becoming revolutionary in the AEC industry. Taylor et al. outline a few methods of integrating BIM into the construction management curriculum. Also, other courses in the curriculum, which are prerequisites to BIM and deliver fundamental skills on digital visualization, CAD drafting, and $3 \mathrm{D}$ modeling, are briefly introduced by the authors [16]. In 2009, Succar presents the 


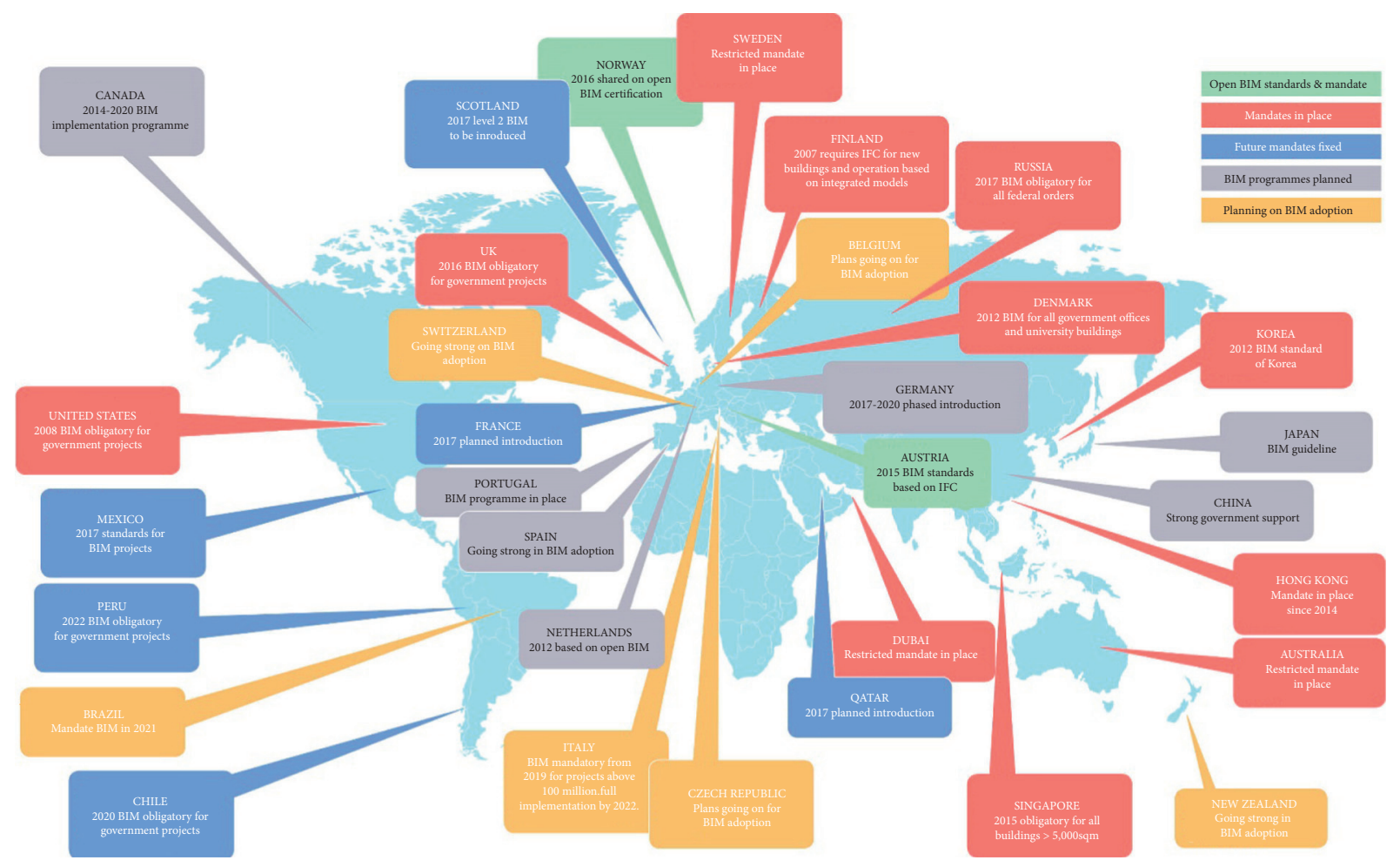

Figure 1: Overview of global BIM adoption [8].

aforementioned methods in addition to the technical definition of BIM. To manage the vital building design and project data throughout the building's lifecycle, BIM includes a set of interacting disciplines that creates a methodology to manage the essential building design and project data in digital format throughout the building's lifecycle [17]. Sabongi and Arch tried to identify the existence and prevalence of undergraduate courses in building information modeling (BIM) and its obstacles. A survey was made determining whether BIM should be offered as stand-alone courses or as a part of other courses, and the disadvantages of offering BIM in the curriculum. According to the results, the current requirements for graduation and the inability for additional elective courses proved to be the most important reasons [18]. Sharag-Eldin and Nawari focused on the experiences gained from introducing BIM to the comprehensive design studio at different institutions and for the senior architectural students at KSU, and BIM was implemented as the primary design tool to develop architectural, structural, and MEP design [19]. Claiming that BIM's method in education and industry are not fully in place, Clevenger et al. present Colorado State University's (CSU) Construction Management Department's approach, to promote BIM-enabled learning. Through ongoing investigation and pilot implementation, they seek to understand and accommodate the impendent transformational shift in construction management education and curriculum development, using the BIM, for better learning [20]. Sacks and Barak stated that Building Information Modeling (BIM) skills are a significant part of improving the use of technology. Civil engineers will not meet the required capabilities of the construction industry if they are not familiar with BIM. It is stated that BIM should be taught in its own right and not as an extension to computeraided drawing [21]. It is explained by Wong et al. that educators around the world are enabling students to apply BIM in their future careers by trying to teach BIM in various methods. To incorporate BIM in the construction management, these approaches are considered along with the help of the Department of Building and Real Estate (BRE) of the Hong Kong Polytechnic University (PolyU) [22]. In a comprehensive paper, Azhar presents current trends, benefits, possible risks, and future challenges of BIM for the architecture, engineering, and construction (AEC) industry [23]. Joannides et al. analyzed the implementation of BIM and assessed training progression of BIM in architecture and construction academic programs. In addition, through a survey sent to architecture and construction schools in the U.S, the implementation of BIM into accredited programs in the aforementioned schools was investigated. The survey results illustrate that, in most architecture and construction schools, having an interest or an already implemented BIM into the curriculum is evident [24]. Sacks and Pikas compile a framework for BIM education that lays out the necessary topics and the levels of achievement required at each stage of programs. Industry's requirements for graduate engineers were elicited through surveys, workshops, analyses of job advertisements, and in-depth interviews [25]. Ho, Tserng, and Jan had carried out study on "Enhancing Knowledge Sharing Management Using BIM Technology in Construction" and proposed a knowledge-sharing management method that facilitates convenient updating and transfer of information and keeping information in a digital format 
using BIM technology. In research, Bryde et al. gather data from 35 construction projects. These projects used BIM technology. A set of project success criteria is used appraising each individual project to meet a criterion, and consequently, the most prominent benefits of the cost reduction and control through the project life cycle are presented [26]. To muster all of BIM's benefits, Lindblad presents an extensive list of BIM benefits, including the efficiency of handling projects or building-related information, construction processes, productivity increase, economic and environmental benefits including cost reductions, improved product quality, improved time management, data exchange, improved client communications, faster analyses, less data input and transfer errors, enablement of collaborations within and across industries, and improved building performance [27]. Fox point out a multitude of real-life instances through a case study, where the application of BIM has been misconducted, culminating in counterproductive results. They assert that many implications of implementing BIM have causal interrelationships that are often overlooked [28]. In the following years, some research studies have been carried out on BIM applications. Zhou presents that the application of BIM technology has provided diverse implications for each phase of the whole construction life cycle. In 2009, Wisconsin became the first state requiring the application of BIM on new large-scale public construction projects built within the state [29]. Fox tried to illustrate critical, realistic descriptions and explain their advantages compared to BIM hype descriptions [28]. The research carried out by Nawari et al. explores BIM tools in creating structural analytical models and their usage to perform structural analysis. Learning basics of structural analysis, promoting group thinking, improving digital modeling, and enhancing professional qualities to fulfill today's demands, as well as tomorrow's integrated practice environments are the main objectives of the proposed BIM approach [30]. Liu and Liu's research shows that, in 2010, Ohio enacted a BIM agreement, and Japan's Ministry of Land, Infrastructure, and Transport announced the implementation of BIM technology. Europe as well as South Korea have also had a number of government agencies promoting the development of BIM applications [6]. According to the research carried out by Nawari and Alsaffar, students in the Middle East and Africa are behind in gaining new advancements such as BIM, and there should be an education program for future architects and engineers in these areas about these developments. This research aims to address challenges over the implementation of BIM into academic organizations' curricula and provide a general framework for introducing BIM knowledge to Kuwait-based students [31]. To explain BIM applications, Lee et al. [32] present that the revolution of BIM technology has influenced the traditional civil construction workflow and processes. Among traditional and innovative thinking, BIM has brought the essence of enhanced quality and efficiency into civil and architecture industries. In addition to the engineering applications throughout the complete lifecycle of the building, BIM technology offers additional benefits such as help to the production of high-quality animation and simulation of construction development, as well as providing the visualized communication platform for different sectors to understand the project portfolio in an effective way. Abanda et al.'s research explains using BIM on the traditional construction industry. Considering that the off-site manufacturing is factory-based, the benefits of applying BIM on off-site manufacturing have been presented compared to traditional construction [33]. Another research has focused on the development of a BIM generative framework (G-BIM) using Cloud technologies and identifying effectiveness factors on successful collaborations [34]. Abd Jamil and Fathi concentrate on three areas where BIM could be effectively employed: BIM functionality, BIM legal issues, and contract procurement issues and then study the impact of applying BIM methods on them [35]. Related to this subject, Marefat et al. develop a BIM approach for construction safety and its benefits based on a questionnaire survey distributed among 200 companies that are active in construction project management [36]. Abd Jamil and Fathi tried to investigate an extension of BIM usage, impacting the legal and contractual implications of the existing construction contracts, for aligning relevant development domains [35]. Boton and Forgues had carried out research on "Practices and Processes in BIM Projects: An Exploratory Case Study" and illustrated certain discrepancies and gaps that might emerge in the actual application of BIM in practice as opposed to the to-be plan, based on a real implementation case study in construction. Almuntaser et al. applied an approach aiming for creating a framework to adopt BIM in the AEC industry. In this approach, various stages, benefits, and challenges of BIM implementation in a pilot project were documented, and then, a BIM maturity evaluation of the pilot project was conducted [37]. According to the research carried out by Sabet and Chong, off-site manufacturing (OSM) and BIM are introduced as revolutionary approaches in the construction industry. Considering the benefits and limitations of these approaches, the capabilities of OSM and BIM techniques have been reviewed [38]. Vilutiene et al. had carried out research on "Advanced BIM Applications in the Construction Industry" and studied current and advanced developments of BIM that were not yet fully incorporated in construction industry due to risks and challenges brought on by its application. They also conducted a critical analysis of BIM pillars in practice and scrutinized the relationship between Off-Site Manufacturing (OSM) and BIM and their concurrent application for improving the productivity of a manufacturing enterprise. They, additionally, cite possible impediments which these methods pose for improvements, in the event of being fallaciously applied [39]. Sackey et al. tried to illustrate the roles of knowledge and requisite skills in better response to creation, dealing with everlasting organizational transformation and construction challenges [40]. By conducting questionnaire surveys and subsequent interviews with BIM practitioners, Blay et al. attempted to reduce challenges and increase the benefits of managing changes in BIM projects. The results showed that the most significant opportunities to increase benefits and reduce challenges were mainly socially driven [41]. Oyewole and Dada assessed the training gaps between the expected knowledge of BIM practice among construction professionals 
through questionnaires in Nigeria. This study revealed that, in order to confirm the efficiency in construction projects, training gaps for BIM application must be met [42]. Various research studies have been performed relating to BIM adoption in construction projects which have found many benefits over traditional construction practices [5]. For example, Ghannadpoor et al. analyze the BIM influence on construction project management, by engaging the FANP-VIKOR decisionmaking method [43]. Rezahoseini et al. analyze the effects of rework and its related factors on the construction projects and introduce the necessity for implementing the TQM system and a model through BIM tool [44]. In the newest research studies on the BIM subject, there are surveys on BIM levels' subject. Level 0 efficiently means no teamwork. Only 2D CAD drafting is utilized, mostly for production information. Paper-based, electronic prints, or a combination of the two are used for output and distribution. The majority of the industry is already well ahead of this approach by now. Level 1 naturally comprises a mixture of $3 \mathrm{D}$ CAD for conceptual works, and 2D for drafting of legal approval documentation and Production Information. CAD standards are managed by BS 1192:2007 and the electronic communication of date is often managed by the contractor. Level 2 BIM needs "an information exchange process which is specific to that project and coordinated between various systems and project participants." Level 3 has not yet been fully pellucid; however, the vision for this is outlined in the UK Government's Level 3 Strategic Plan. For example, Blay et al. present BIM level 2 project change management and its benefits and challenges by a questionnaire survey and interviewing BIM experts [41]. Like all new technologies, the implementation of BIM also has challenges. According to the literature related to BIM subject, research gaps are as follows:

(i) There are many surveyed papers on BIM, but there is no paper that works on gathering them and identifying the most important challenges of BIM implementation.

(ii) Relationships between challenges as well as the influencing and influenced challenges of BIM implementation have not been recognized. This study strives to identify these objects.

(iii) A hierarchical network of the challenges has not been delineated. This study tries to design such a network and show the position of each challenge from an influencing point of view.

\section{Methodology}

3.1. Research Framework. The framework of this research is presented in the first part of the methodology, which consists of 4 parts. As shown in Figure 2, step (1) describes how to identify and sift the challenges of implementation of the BIM; step (2) describes how to define the fuzzy Znumber spectrum; step (3) describes the steps of DEMATEL and evaluates the final weights and the amount of influences; at step (4), the analysis of ISM is performed and the final hierarchical model is obtained. Due to the capability of the DEMTEL method in calculating the impacts of the challenges of implementing BIM along with ranking these challenges in terms of their weights, the DEMATEL method was used in this study. The challenges also have interdependent relationships and cannot be considered independent; therefore, other weighting methods are not suitable to be used. At the end of the DEMATEL method, a zero matrix is obtained together with a matrix indicating whether there are any interactions between the challenges or not. Using this matrix and the ISM method, it will be possible to achieve a specific grading for the most effective challenges. The DEMATEL-ISM combination is also an efficient combination for finding the most important challenges, since, in addition to the same output and input the DEMATEL and ISM methods, it satisfies the research objectives as well.

3.2. Step (1): Challenge Identification. Given the importance of implementing BIM and challenges that we face while implementing it, in this section, using past studies and expert opinions, we identified the existing challenges and categorized these challenges, which are described in Table 1. There are 3 steps as follows:

(1) Identify challenges of implementation of BIM

(2) Categorize the challenges into four categories

(3) Filtering these challenges based on expert opinion and geographical area

49 initial challenges of implementation of BIM were found and categorized into four areas. These four areas are technology, economics, operational, and law. Relative challenges and their references are mentioned in Table 1.

At first, a questionnaire was provided to collect the BIM expert's opinions. These experts include 6 university professors, 5 Ph.D. and masters students who research on BIM subject, and 9 experts who have experience in the field of BIM. These people rated the impact of each challenge on the implementation of BIM from 1 to 5 . The averages of these scores were calculated for each challenge; then, the average of averages was obtained. Each average value that is greater than the average of averages will be selected. Finally, the final 15 challenges were achieved. Table 2 shows the selected challenges. In the next steps, these challenges will be used to find important, influencing, and influenced challenges.

3.3. Step (2): Z-Number. Awareness of the status of the challenges of implementing BIM is done by paired comparison questionnaire and expert opinion polls in this field. Since the opinions of experts are associated with uncertainty, fuzzy numbers are used to obtain the correct results. Depending on the nature of the membership function, a fuzzy number can be classified in different ways, such as a triangular fuzzy number (TFN) and trapezoidal fuzzy number. Triangular fuzzy numbers (TFNs) are applied frequently. It is well known that the matrix formulation of a mathematical formula gives an extra facility to solve the problem. Triangular fuzzy matrices (TFMs) are introduced to present uncertainty of experts' opinions in many 


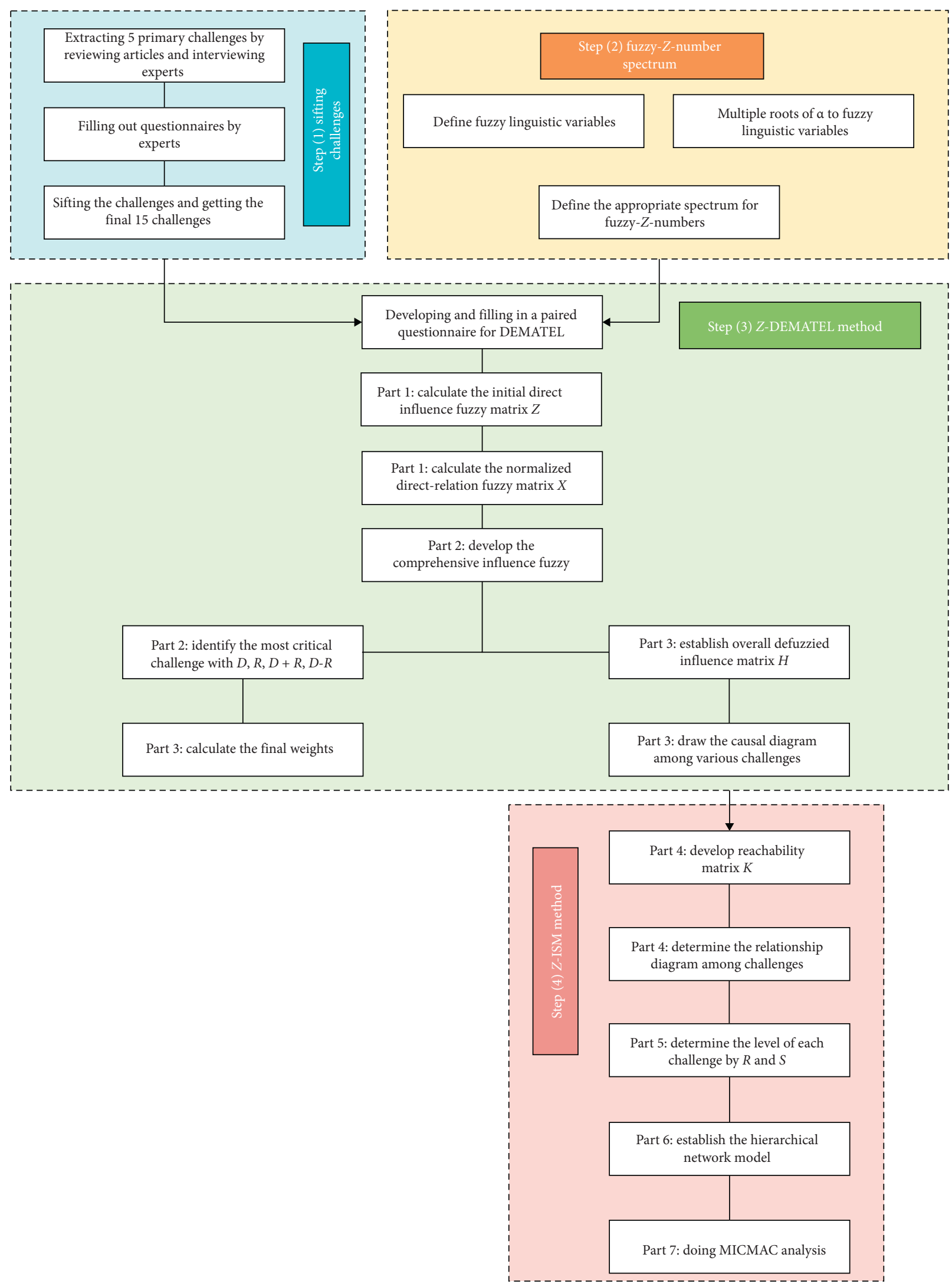

Figure 2: Framework of the research. 
TABLE 1: Challenges found through BIM implementation.

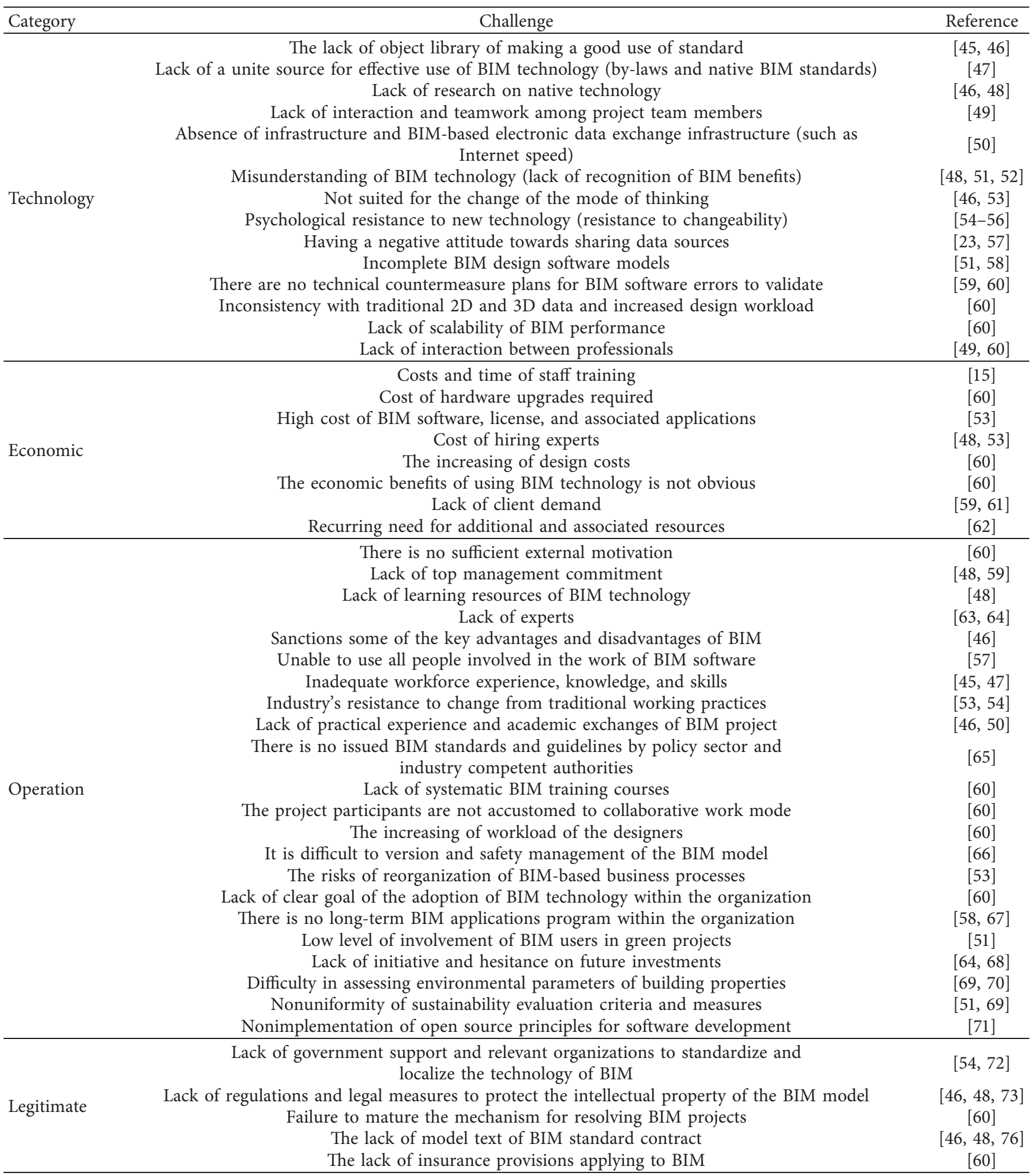

mathematical formulations in different science and technology. After TFN and TFM, Z-number can be presented which considers the probability of TFN [75].

$\mathrm{Z}$-number is made of three components with the structure $(X, A, B)$. Clearly, to find unreliability, most of the data and decision-making problems are associated with Z- information, though they are not treated as such for the sake of hard calculations [76]. Kang et al. [77] suggest a model for converting Z-numbers to conventional fuzzy sets to simplify the computations and subsequently develop the wide applications of Z-numbers. According to [78], for a pair of Znumber $(A, B)$, if $X$ is a random variable with a specific 
TABle 2: Examined challenges of BIM implementation.

\begin{tabular}{ccc}
\hline Category & Code & Challenge \\
\hline & T1 & Lack of a single source for effective use of BIM technology (by laws and native BIM standards) \\
T2 & Lack of interaction and teamwork among project team members \\
Technology & T3 & Absence of infrastructure and BIM-based electronic data exchange infrastructure (such as internet speed) \\
& T4 & Misunderstanding of BIM technology (lack of recognition of BIM benefits) \\
& T5 & Psychological resistance to new technology (resistance to changeability) \\
& T6 & Having a negative attitude towards sharing data sources
\end{tabular}

distribution, then $X$ is $A$ which indicates a fuzzy event in $R$ with the probability in equation (1):

$$
p=\int_{R} \mu_{A}(u) p_{x}(u) d_{u}
$$

where $p_{x}$ is the probability distribution of $X$. As a limit, the structure $(X, A, B)$ will be expressed on $X$ as shown in equation (2): [78]:

$$
\operatorname{Prob}(X \text { is } A) \text { is } B \text {. }
$$

Using equation (1), $\operatorname{Prob}(X$ is $A$ ) is $B$, which would be replaced with $p=\int_{R} \mu_{A}(u) p_{x}(u) d_{u}$ as shown in equation (3):

$$
p=\int_{R} \mu_{A}(u) p_{x}(u) d_{u} \text { is } B .
$$

Regarding probability rules, the complement of $Z$ is $Z^{\prime}$. As an example, the complement of Z-number $(A, B)$ is $\left(A^{\prime}, 1-B\right)$ or events in $R$, except for $1,1-B$.

The concept of $Z^{+}$-number which is closely relevant to the concept of $\mathrm{Z}$-numbers is basically an ordered pair of $(A, R)$ in which $A$ plays the same role that it does in $\mathrm{Z}$ numbers and $R$ is the probability distribution of a random number [78]. Furthermore, a $Z^{+}$-number could be defined as a pair $\left(\mu_{A}, p_{X}\right)$ in which $A$ plays the role of the membership function of $A$ and $p_{x}$ indicates the probability distribution of $X$. Actually, the difference between $Z$-number and $Z^{+}$-number is the fact that, in Z-numbers, $p_{x}$ (probability distribution) is unknown; however, the probability value of $A$ is recognized [78]. The relations between the $Z^{+}$-number and Z-number are elucidated in equation (4) as follows [79]:

$$
Z(A, B)=Z^{+}\left(A, \mu_{A} \cdot p_{X} \text { is } B\right) \text {. }
$$

According to the fuzzy model which is presented by Kang et al. [77], for a specific $Z$-number with the pair of $Z=(A, B), \widetilde{B}=\left\{\left(x, \mu_{\widetilde{B}}(x) \mid x \varepsilon[0,1]\right\}\right.$ denotes the fuzzy reliability value of and $\mu_{B}(x)$ indicates the membership function. Meanwhile, the crisp centroid (center of gravity) value of $\widetilde{B}$ will be computed as equation (5) as follows:

$$
\alpha=\frac{\int x \mu_{B}(x) d_{x}}{\int \mu_{B}(x) d_{x}} .
$$

If $\widetilde{B} \sim \operatorname{TrFS}[a, b, c]$, then the centroid defuzzification of this set is $(a+b+c) / 3$. If $\bar{A} \sim \operatorname{TrFS}[d, e, f]$, the fuzzy Z-number will be finally concluded as shown in equation (6): [77]

$$
A^{\prime}=[\sqrt{\alpha} d, \sqrt{\alpha} e, \sqrt{\alpha} f]=\left[d^{\prime}, e^{\prime}, f^{\prime}\right] .
$$

In Table 3, Z-number corresponding possibilities are available.

As shown in Figure 3, in such cases, the Z-number can possibly be defined as a simple fuzzy set $(\alpha \leq 1)$.

For example (VL, U) refers to very Low and unlikely:

$$
[0,0.25,0.5] \times 0.45=[0,0.11,0.22] .
$$

Table 4 shows the final fuzzy Z-number corresponding possibilities and linguistic variables in fuzzy formation. Due to the fact that $Z$-number is closer to the opinions of experts, $\mathrm{Z}$-number is applied. In the table below, corresponding Znumber applied set is obtained from the fuzzy state.

\subsection{Step (3) and Step (4): Integrated DEMATEL-ISM Method.} After finding the challenges and categorizing and filtering them, DEMATEL and ISM approaches are applied to find the most important challenges: influencing challenges and influenced challenges. The influencing challenges are the challenges that once decided upon, addressed or prioritized over other factors, and have the highest effect on other factors. Adversely, the influenced challenges are the ones that would be affected or changed the most, as a result of other factor's changing. In other words, they are more tractable. Subsequently, DEMATEL and ISM approaches are described in the following.

Various steps in the integrated DEMATEL-ISM approach are given below, where 3 preliminary steps from the DEMATEL method are used to calculate the overall interactions among various challenges and identify the most critical 
TABLE 3: Z-number corresponding possibilities.

\begin{tabular}{lccc}
\hline Linguistic variable & Corresponding possibilities & $\alpha$ & $\sqrt{\alpha}$ \\
\hline Unlikely & {$[0.1,0.2,0.3]$} & 0.2 & 0.45 \\
Fairly impossible & {$[0.3,0.4,0.5]$} & 0.3 & 0.63 \\
Weak & {$[0.4,0.5,0.6]$} & 0.5 & 0.71 \\
Maybe & {$[0.5,0.6,0.7]$} & 0.6 & 0.77 \\
Likely & {$[0.7,0.8,0.9]$} & 0.8 & 0.89 \\
Most likely & {$[0.8,0.9,1]$} & 0.9 & 0.95 \\
Certainly & {$[1,1,1]$} & 1 & 1 \\
\hline
\end{tabular}

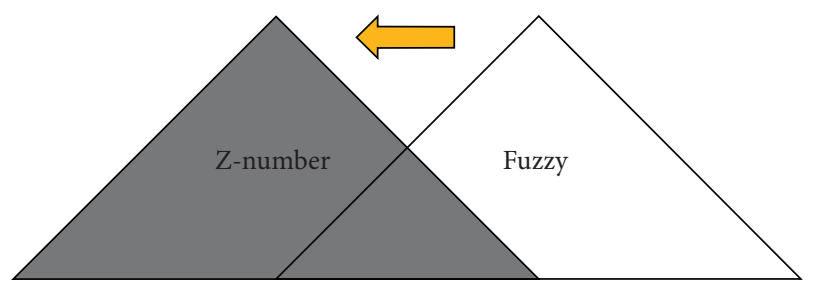

Figure 3: Compression between fuzzy and fuzzy Z-number environment.

challenges. Then, the ISM method is integrated by following parts to determine the hierarchical structure of the challenges.

3.4.1. Part 1: Establish the Initial Direct Influence Matrix $\mathbf{Z}$. The challenges of BIM implementation are denoted as $C=\{C 1, C 2, \ldots, C n\}$. Assume that the scales $0,1,2,3$, and 4 represent the range from "no influence" to "very high influence" [80]. $n$ Experts are asked to propose the influences among these challenges based on pairwise challenge comparisons in terms of influencing degree and directions. The decision maker assesses the alternatives upon the given challenge. In this step of the proposed model, the relationship among the challenge is determined by using the modified fuzzy DEMATEL method. The modified fuzzy Znumber DEMATEL method is initially built to create the average direct relation of fuzzy matrix $\widetilde{Z}$, where $\widetilde{Z}$ is $(n \times n)$ matrix and $n$ represents the number of challenges. The direct relation matrices are all obtained by holding a pairwise comparison among the challenges themselves in which $\widetilde{Z}_{i j}$ indicates the average degree to which challenge $C_{i}$ influences challenge $C_{i j}$; therefore, the relationship among the challenges could be held within a matrix.

In this method, the effects of the challenges on each other are expressed in terms of linguistic expressions. A triangular fuzzy number can be denoted by $(l, m, u) . \widetilde{Z}$ Matrix is given in equation (8), where $\widetilde{F}=\left(F_{i j, l}, F_{i j, m}, F_{i j, u}\right)$ and $\widetilde{Z}=\sqrt{\alpha} \widetilde{F}=$ $\sqrt{\alpha}\left(F_{i j, l}, F_{i j, m}, F_{i j, u}\right)=\left(Z_{i j, l}, Z_{i j, m}, Z_{i j, u}\right):$

$$
\widetilde{Z}=\cdot \begin{aligned}
& C_{1} \\
& C_{2} \\
& \cdot \\
& \cdot \\
& \quad \\
& C_{n}
\end{aligned}\left[\begin{array}{cccc}
0 & \widetilde{Z}_{12} & \ldots & \widetilde{Z}_{1 n} \\
\widetilde{Z}_{21} & 0 & \ldots & \widetilde{Z}_{2 n} \\
\cdot & & & \cdot \\
\cdot & & & \cdot \\
\tilde{Z}_{n 1} & \widetilde{Z}_{n 2} & \ldots & \widetilde{Z}_{n 3}
\end{array}\right] \cdot
$$

$\widetilde{Z}$ matrix is transformed into normalized one via some steps. This is done so as to compare the linguistic expressions given by the decision maker. The normalized direct-relation fuzzy matrix denoted by $\widetilde{X}$ is given by equations (9)-(11) (see [80]):

$$
\begin{aligned}
& \widetilde{X}_{i j}=\frac{\widetilde{Z}_{i j}}{R}=\left(\frac{\widetilde{Z}_{i j, l}}{r_{l}}, \frac{\widetilde{Z}_{i j, m}}{r_{m}}, \frac{\widetilde{Z}_{i j}, u}{r_{u}}\right), \\
& R=\left(\widetilde{Z}_{i j, l}, \widetilde{Z}_{i j, m}, \widetilde{Z}_{i j}, u\right) \text {, } \\
& r_{s}=\max _{1 \leq i \leq n}\left(\sum_{j=1}^{n} Z_{i j, s} 1 \leq i \leq n\right), \quad \forall s=l, m, u, \\
& \widetilde{X}=\left[\begin{array}{cccc}
\widetilde{X}_{11} & \widetilde{X}_{12} & \ldots & \widetilde{X}_{1 n} \\
\widetilde{X}_{21} & \widetilde{X}_{22} & \ldots & \widetilde{X}_{2 n} \\
\cdot & & & \cdot \\
\cdot & & & \cdot \\
\cdot & & & \cdot \\
\widetilde{X}_{n 1} & \widetilde{X}_{n 2} & \ldots & \widetilde{X}_{n n}
\end{array}\right] .
\end{aligned}
$$

3.4.2. Part 2: Establish the Comprehensive Influence Matrix $\widetilde{T}$. The initial normalized direct-relation fuzzy matrix can be separated into separate submatrices, i.e., $\left(X_{l}, X_{m}, X_{u}\right)$. Therefore, the total-relation fuzzy matrix $\widetilde{T}$ can be acquired by calculating as shown in equation (12):

$$
\widetilde{T}=\tilde{X}(I-\widetilde{X})^{-1} .
$$

Therefore, $\widetilde{T}$ matrix could be represented as shown in equation (13):

$$
\widetilde{T}=\left[\begin{array}{cccc}
\tilde{t}_{11} & \widetilde{t}_{12} & \ldots & \widetilde{t}_{1 n} \\
\widetilde{t}_{21} & \widetilde{t}_{22} & \ldots & \widetilde{t}_{2 n} \\
\cdot & & & \cdot \\
\cdot & & & \cdot \\
\cdot & & & \cdot \\
\tilde{t}_{n 1} & \widetilde{t}_{n 2} & \ldots & \widetilde{t}_{n n}
\end{array}\right],
$$

where $\widetilde{t}_{i j}=\left(t_{i j, l}, t_{i j, m}, t_{i j, u}\right)$ is the overall influence rating of the decision maker for each challenge $i$ against challenge $\bar{j}$. The most critical challenges can be identified on the basis of $\widetilde{T}$ matrix. The sum of rows and sum of columns of the submatrices $T_{l}, T_{m}$, and $T_{u}$ denoted by the fuzzy numbers $\widetilde{D}_{i}$ and $\widetilde{R}_{i}$, respectively, can be obtained through equations (14)-(17) (see [81]). For any challenge $x_{i}(i=1,2, \ldots, n)$, the influencing degree $\widetilde{D}_{i}$ represents the comprehensive influence of the challenge $x_{i}$ on the other $f$ challenge. The influenced degree $\widetilde{R}_{i}$ represents the comprehensive influence from other challenges on challenge $x_{i}$. The centrality, $\widetilde{D}_{i}+\widetilde{R}_{i}$, reflects the importance of challenge $x_{i}$ in the entire risk system, where challenges with higher centrality are more important. The causality, $\widetilde{D}_{i}-\widetilde{R}_{i}$, reflects the pure influences of challenge $x_{i}$ on other challenges. Challenges with positive causality are causal challenges, while challenges with 
TABLe 4: Fuzzy Z-number corresponding possibilities.

\begin{tabular}{|c|c|c|c|}
\hline Linguistic variable & Abbreviation & Corresponding fuzzy applied set & Corresponding Z-number applied set \\
\hline No effect-unlikely & $(\mathrm{NO}, \mathrm{U})$ & {$[0,0,0.25]$} & {$[0,0,0.11]$} \\
\hline No effect-fairly impossible & $(\mathrm{NO}, \mathrm{FI})$ & {$[0,0,0.25]$} & {$[0,0,0.16]$} \\
\hline No effect-weak & $(\mathrm{NO}, \mathrm{W})$ & {$[0,0,0.25]$} & {$[0,0,0.18]$} \\
\hline No effect-maybe & $(\mathrm{NO}, \mathrm{M})$ & {$[0,0,0.25]$} & {$[0,0,0.19]$} \\
\hline No effect-likely & $(\mathrm{NO}, \mathrm{L})$ & {$[0,0,0.25]$} & {$[0,0,0.22]$} \\
\hline No effect-most likely & $(\mathrm{NO}, \mathrm{ML})$ & {$[0,0,0.25]$} & {$[0,0,0.24]$} \\
\hline No effect-certainly & $(\mathrm{NO}, \mathrm{C})$ & {$[0,0,0.25]$} & {$[0,0,0.25]$} \\
\hline Very low-unlikely & $(\mathrm{VL}, \mathrm{U})$ & {$[0,0.25,0.5]$} & {$[0,0.11,0.22]$} \\
\hline Very low-fairly impossible & $(\mathrm{VL}, \mathrm{FI})$ & {$[0,0.25,0.5]$} & {$[0,0.16,0.32]$} \\
\hline Very low-weak & $(\mathrm{VL}, \mathrm{W})$ & {$[0,0.25,0.5]$} & {$[0,0.18,0.35]$} \\
\hline Very low-maybe & $(\mathrm{VL}, \mathrm{M})$ & {$[0,0.25,0.5]$} & {$[0,0.19,0.39]$} \\
\hline Very low-likely & $(\mathrm{VL}, \mathrm{L})$ & {$[0,0.25,0.5]$} & {$[0,0.22,0.45]$} \\
\hline Very low-most likely & $(\mathrm{VL}, \mathrm{ML})$ & {$[0,0.25,0.5]$} & {$[0,0.24,0.47]$} \\
\hline Very low-certainly & $(\mathrm{VL}, \mathrm{C})$ & {$[0,0.25,0.5]$} & {$[0,0.25,0.5]$} \\
\hline Low-unlikely & $(\mathrm{L}, \mathrm{U})$ & {$[0.25,0.5,0.75]$} & {$[0.11,0.22,0.34]$} \\
\hline Low-fairly impossible & $(\mathrm{L}, \mathrm{FI})$ & {$[0.25,0.5,0.75]$} & {$[0.16,0.32,0.47]$} \\
\hline Low-weak & $(\mathrm{L}, \mathrm{W})$ & {$[0.25,0.5,0.75]$} & {$[0.18,0.35,0.53]$} \\
\hline Low-maybe & $(\mathrm{L}, \mathrm{M})$ & {$[0.25,0.5,0.75]$} & {$[0.19,0.39,0.58]$} \\
\hline Low-likely & $(\mathrm{L}, \mathrm{L})$ & {$[0.25,0.5,0.75]$} & {$[0.22,0.45,0.67]$} \\
\hline Low-most likely & $(\mathrm{L}, \mathrm{ML})$ & {$[0.25,0.5,0.75]$} & {$[0.24,0.47,0.71]$} \\
\hline Low-certainly & $(\mathrm{L}, \mathrm{C})$ & {$[0.25,0.5,0.75]$} & {$[0.25,0.5,0.75]$} \\
\hline High-unlikely & $(\mathrm{H}, \mathrm{U})$ & {$[0.5,0.75,1]$} & {$[0.22,0.34,0.45]$} \\
\hline High-fairly impossible & $(\mathrm{H}, \mathrm{FI})$ & {$[0.5,0.75,1]$} & {$[0.32,0.47,0.63]$} \\
\hline High-weak & $(\mathrm{H}, \mathrm{W})$ & {$[0.5,0.75,1]$} & {$[0.35,0.53,0.71]$} \\
\hline High-maybe & $(\mathrm{H}, \mathrm{M})$ & {$[0.5,0.75,1]$} & {$[0.39,0.58,0.77]$} \\
\hline High-likely & $(\mathrm{H}, \mathrm{L})$ & {$[0.5,0.75,1]$} & {$[0.45,0.67,0.89]$} \\
\hline High-most likely & $(\mathrm{H}, \mathrm{ML})$ & {$[0.5,0.75,1]$} & {$[0.47,0.71,0.95]$} \\
\hline High-certainly & $(\mathrm{H}, \mathrm{C})$ & {$[0.5,0.75,1]$} & {$[0.5,0.75,1]$} \\
\hline Very high-unlikely & $(\mathrm{VH}, \mathrm{U})$ & {$[0.75,1,1]$} & {$[0.34,0.45,0.45]$} \\
\hline Very high-fairly impossible & $(\mathrm{VH}, \mathrm{FI})$ & {$[0.75,1,1]$} & {$[0.47,0.63,0.63]$} \\
\hline Very high-weak & $(\mathrm{VH}, \mathrm{W})$ & {$[0.75,1,1]$} & {$[0.53,0.71,0.71]$} \\
\hline Very high-maybe & $(\mathrm{VH}, \mathrm{M})$ & {$[0.75,1,1]$} & {$[0.58,0.77,0.77]$} \\
\hline Very high-likely & $(\mathrm{VH}, \mathrm{L})$ & {$[0.75,1,1]$} & {$[0.67,0.89,0.89]$} \\
\hline Very high-most likely & $(\mathrm{VH}, \mathrm{ML})$ & {$[0.75,1,1]$} & {$[0.71,0.95,0.95]$} \\
\hline Very high-certainly & $(\mathrm{VH}, \mathrm{C})$ & {$[0.75,1,1]$} & {$[0.75,1,1]$} \\
\hline
\end{tabular}

negative causality are effect challenges. These parameters can be calculated by equations (14)-(17), respectively. A causal diagram can then be obtained and $\widetilde{D}_{i}+\widetilde{R}_{i}$ and $\widetilde{D}_{i}-\widetilde{R}_{i}$ represent the datasets composed by $\widetilde{D}_{i}+\widetilde{R}_{i}(i=1,2, \ldots, n)$ and $\widetilde{D}_{i}-\widetilde{R}_{i}(i=1,2, \ldots, n)$, respectively:

$$
\begin{gathered}
\widetilde{D}_{i}=\sum_{j=1}^{n} t_{i j}, \quad i=1,2, \ldots, n, \\
\widetilde{R}_{i}=\sum_{j=1}^{n} t_{i j}, \quad i=1,2, \ldots, n, \\
\widetilde{D}_{i}+\widetilde{R}_{i}, \quad i=1,2, \ldots, n, \\
\widetilde{D}_{i}-\widetilde{R}_{i}, \quad i=1,2, \ldots, n .
\end{gathered}
$$

3.4.3. Part 3: Establish Overall Defuzzy Influence Matrix $H$ [82]. The distance of $\widetilde{T}$ matrix is used as its Defuzzy value. After this defuzzification, the $H$ matrix is obtained. Equation (18) is usable for defuzzification of $\widetilde{D}_{i}$ and $\widetilde{R}_{i}$ too [83]:

$$
S\left(\widetilde{t}_{i j}, 0\right)=\frac{1}{4}\left(\widetilde{t}_{i j, l}+2 \times \widetilde{t}_{i j, m}+\tilde{t}_{i j, u}\right) .
$$

The weight of each challenge is calculated as shown in equation (19): [81]

$$
\omega_{i}=\sqrt[2]{\left(\widetilde{D}_{i}^{\text {def }}+\widetilde{R}_{i}^{\text {def }}\right)^{2}+\left(\widetilde{D}_{i}^{\text {def }}+\widetilde{R}_{i}^{\text {def }}\right)^{2}} .
$$

The weight of any challenge can be normalized as shown in equation (20):

$$
w_{i}=\frac{\omega_{i}}{\sum_{i-1}^{n} \omega_{i}}
$$

3.4.4. Part 4: Establish Reachability Matrix K and Determine the Relationship Diagram among Challenges [84]. Each element $h_{i j}$ of matrix $H$ provides network of information as to how the challenge $x_{i}$ affects challenge $x_{j}(i, j=1,2, \ldots, n)$. In order to isolate the relation structure of the challenges, setting a threshold value to filter out minor effects denoted by elements of matrix $H$ is necessary. The goal of filtering is to highlight major challenges in BIM in order to avoid over-simplification. Given a threshold $\lambda$, reachability matrix $K\left(K=\left[k_{i j}\right]\right)$ can be derived 
using equations (21) and (22), where $k_{i j}=1$ means challenge $x_{i}$ can directly affect challenge $x_{j}(i, j,=1,2, \ldots, n)$; thus, the cause-effect relations among challenges can be determined:

$$
\begin{gathered}
\lambda=\frac{\sum_{i} \sum_{j} h_{i j}}{n \times n}, \\
k_{i j}= \begin{cases}1, & \text { if } h_{i j} \geq \lambda(i, j=1,2, \ldots, n), \\
0, & \text { if } h_{i j}<\lambda(i, j=1,2, \ldots, n) .\end{cases}
\end{gathered}
$$

Besides, there are two major principles for the determination of the threshold $\lambda$ :

Node degree of each challenge should be moderate

Challenges with a larger node degree should be included in the critical challenges identified by Step 2 of DEMATEL analysis

Node degree of each challenge, symbolled as $f_{i}(i=$ $1,2, \ldots, n)$ in this study, can be calculated by equation (23). By conducting several tests, the most appropriate value of $\lambda$ to be used for acquiring a suitable relationship can be obtained:

$$
f_{i}=\sum_{i \neq j} k_{i j}, \quad i=1,2, \ldots, n .
$$

3.4.5. Part 5: Determine the Level of Each Challenge. Before a challenge $x_{i}(i=1,2, \ldots, n)$ can be classified to a certain level, the corresponding reachable set $R_{i}$ and antecedent set $S_{i}$ should be determined, which can be written as equations (24) and (25):

$$
\begin{aligned}
& R_{i}=\left\{x_{j} \mid x_{j} \in X, k_{i j}=1, j=1,2, \ldots, n\right\}, \quad i=1,2, \ldots, n, \\
& S_{i}=\left\{x_{j} \mid x_{j} \in X, k_{j i}=1, j=1,2, \ldots, n\right\}, \quad i=1,2, \ldots, n .
\end{aligned}
$$

Subsequently, for each challenge $x_{i}(i=1,2, \ldots, n)$, the following equation (26) was validated:

$$
R_{i}=R_{i} \cap S_{i}, \quad i=1,2, \ldots, n .
$$

In regards to challenges satisfying equation (26), other challenges can reach them, but they cannot reach other challenges. Therefore, they are classified into the challenge set of the bottom level. Next, delete the corresponding row and column from the matrix $K$ and repeat the above processes. When all challenges are allocated, the initial diagram can be obtained combining the relations among various challenges determined by Step 4 .

3.4.6. Part 6: Establish the Hierarchical Network Model. After checking for incompatibilities, removing indirect links, and replacing the network nodes with challenge descriptions, the final diagram, referred to as the hierarchical network model in this paper, can be obtained.
3.4.7. Part 7: Analysis of MICMAC. The MICMAC (CrossImpact Matrix Multiplication Applied to the Classification analysis) principle is based on the multiplication properties of matrices [85]. The main objective is to analyze the identified challenges with the help of MICMAC analysis. In this research study, the challenges are categorized into four sectors. The challenges under sector I have weak driving and dependence power, hence are known as autonomous challenges. These autonomous challenges are not linked to the overall system. The challenges under sector II have high dependence power but low driving power, hence are considered as dependent challenges. In sector III, barriers have high dependence and driving power, so these challenges are considered as linkage challenges. Challenges that have high driving power but low dependence power come under sector IV and are called independent challenges [86].

(i) Autonomous challenges have weak driving and dependence power. These challenges have few links with the overall system because of their weak linkage with the other challenges or due to their few influences on the entire system.

(ii) Dependent challenges with very weak driving power and strong dependence are influenced by the independent challenges.

(iii) Linkage challenges have strong driving as well as dependence power.

(iv) Independent challenges have strong driving power and weak dependence power.

\section{Data and Results}

The following tables and results of the methodology are derived according to the questionnaires that have been designed and filled in Iran. The sample size was consisting of 20 individuals, since we tried to only reach out to domain experts in this field.

4.1. Challenge Identification Results. By procedures mentioned in Section 3, 49 challenges were gathered, categorized, and filtered based on experts' opinions. The following challenges are selected Table 2 (this table has been obtained based on the results of the questionnaire in Appendix A).

4.2. Fuzzy Z-Number DEMATEL Results. Fuzzy Z-number DEMATEL results are submitted as follows.

A questionnaire was provided to catch experts' opinions to find out about the challenges of implementing BIM. This questionnaire compares the influencing of challenges on each other. One sample of the questionnaire is shown in Table 5 (the relevant questionnaires from which this table was derived could be found in Appendix B).

According to Step 1 of the methodology, the initial direct influence matrix $\widetilde{Z}$ and the normalized matrix $\widetilde{X}$ are shown in Tables 6 and 7. According to Step 2 and equations (12) and (13), the comprehensive influence matrix $\widetilde{T}$ is shown in Table 8. 
TABLE 5: Sample of questionnaire.

\begin{tabular}{|c|c|c|c|c|c|c|c|c|c|c|c|c|c|c|c|}
\hline & T1 & $\mathrm{T} 2$ & T3 & 4 & T5 & T6 & 1 & $\mathrm{O} 2$ & O3 & E1 & E2 & E3 & 51 & L2 & $\mathrm{L} 2$ \\
\hline$\Gamma 1$ & * & $\mathrm{TO}-\mathrm{C}$ & L-W & 3 & I_L & $J_{-1}$ & - & & ת & I & & & & & IO \\
\hline$\Gamma 2$ & L-FI & 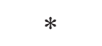 & & & & & & & & & & & & & \\
\hline 3 & & & * & $-M$ & & & & & & & & & & & O-L \\
\hline 4 & & & ML & * & $-M L$ & & & & & & & & & & $\mathrm{O}-\mathrm{L}$ \\
\hline 5 & & & & $\mathrm{~L}-\mathrm{U}$ & $*$ & & & & & & & & & & $\mathrm{O}-\mathrm{L}$ \\
\hline 6 & & & & & & , & & & & & & & & & O-1 \\
\hline 1 & & & & & & & * & & & & & & & & O-L \\
\hline $\mathrm{O} 2$ & & & & & & & & $*$ & & & & & & & $\mathrm{O}-\mathrm{L}$ \\
\hline $\mathrm{O} 3$ & & & & & & & & & 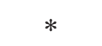 & & & & & & $\mathrm{O}-\mathrm{L}$ \\
\hline 1 & & & & & & & & & & * & & & & & $\mathrm{O}-\mathrm{L}$ \\
\hline 2 & & & 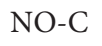 & & & & & & & M & 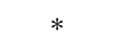 & & & & $\mathrm{O}-\mathrm{L}$ \\
\hline E3 & ML & & $\mathrm{D}-\mathrm{C}$ & $-W$ & $\mathrm{D}-\mathrm{W}$ & & & & & ML & & , & L-W & & JO-L \\
\hline 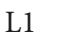 & & & & & & & & & & & & & & & JO-L \\
\hline L2 & & & & $x$ & & & & & & & & & & & $\mathrm{TO}-\mathrm{L}$ \\
\hline L3 & VL-C & $\mathrm{VH}-\mathrm{C}$ & $\mathrm{NO}-\mathrm{C}$ & L-FI & NO-W & NO-FI & L-ML & L-ML & NO-M & NO-L & NO-ML & $\mathrm{NO}-\mathrm{U}$ & NO-L & NO-W & * \\
\hline
\end{tabular}

According to Step 2 and equations (14)-(17), Table 9 shows the importance, relationships, and weights of each challenges resulted from fuzzy Z-number DEMATEL approach.

Table 10 shows that defuzzied influencing, influenced, centrality, causality degrees, and weight are obtained based on equation (18).

Figure 4 shows the centrality $\left(\widetilde{D}_{i}+\widetilde{R}_{j}\right)$ and the causality $\left(\widetilde{D}_{i}-\widetilde{R}_{j}\right)$.

As shown in Figure 4, L1, L2, and L3 are the most influential challenges, respectively. T2, T3, and T6 are the most influenced challenges respectively, too. The challenges above the horizontal axis with positive causality are casual challenges. Their pure influence on other challenges is higher than the influenced degree. On the contrary, challenges below the horizontal axis are influenced challenges. L1 is presented as the most influential challenge and T2 is the most influenced challenge. Challenges on the right part of Figure 4 have higher centrality, and they are more important than challenges on the left part. In this study, all challenges have high centrality and are important, although some of them are more important and more critical to control for preventing risk than others. $\mathrm{T} 4, \mathrm{~T} 2, \mathrm{~T} 5, \mathrm{O} 3, \mathrm{~L} 2$, and $\mathrm{L} 1$ are the most important ones. Matrix $H$ is shown in Table 11.

Table 12 presents reachability matrix $K$.

Figure 5 shows the initial diagram which is derived using nodes and arcs.

According Figures 4 and 5 and Tables 9 and 10, L1 (lack of upstream organization support and to standardize and localize the technology of BIM), L2 (lack of regulations and legal measures to protect the intellectual property of the BIM model), L3 (failure to mature the mechanism for resolving BIM projects), O3 (cost of hiring experts), O2 (cost of hardware upgrades required), E3 (inadequate workforce experience, knowledge, and skills), $\mathrm{O} 1$ (costs and time of staff training), T1 (lack of a single source for effective use of BIM technology (by-laws and native BIM standards)), and E1 (sanctions against some of the key advantages and disadvantages of BIM) are causal challenges which influence other challenges.
T5 (psychological resistance to new technology), T4 (misunderstanding of BIM technology), E2 (unable to use all people involved in the work of BIM software), T6 (having a negative attitude towards sharing data sources), T2 (lack of interaction and teamwork among project team members), and T3 (absence of infrastructure and BIM-based electronic data exchange infrastructure) are challenges caused.

4.3. ISM Results. As mentioned before, the hierarchical network of challenges can be designed by the ISM approach. Table 13 shows the reachable $\left(R_{i}\right)$, antecedent $\left(S_{i}\right)$ sets and their joint set $\left(R_{i} \cap S_{i}\right)$.

The hierarchical network model among the challenges is shown in Figure 6.

As shown in Figure 6, there are 4 levels for this model. The influence is decreasing from the bottom to top. The fourth level is the most influential and the first level is the most influenced challenges. In this approach, the goal is to find influencing and influenced challenges according to reachability matrix $K$ Based on Table 13 and Figure 6, level 1 challenges are more influenced ones and level 4 are more influencing challenges. As it is clear, L1, L2, L3, O3, O2, E3, $\mathrm{O} 1, \mathrm{~T} 1$, and $\mathrm{E} 1$ are level 1 and level 2 challenges.

Given what is mentioned above, lack of upstream organizations' support to standardize and localize the technology of BIM and lack of regulations and legal measures to protect the intellectual property of the BIM model are influencing other challenges. This result clearly demonstrates the importance of upstream organizations' support and appropriate rules ratified by them. New technologies pertaining to any industry need upstream organizations' full attention to embark, grow, and survive. Lack of a single source, misunderstanding of the BIM technology, inadequate workforce experience, cost of hardware, cost of hiring experts, and failure to mature the mechanism are other influencing challenges. The next influencing challenge, as expected, is cost, but another important and influencing context is understanding the new technology and training people accordingly. Lack of 


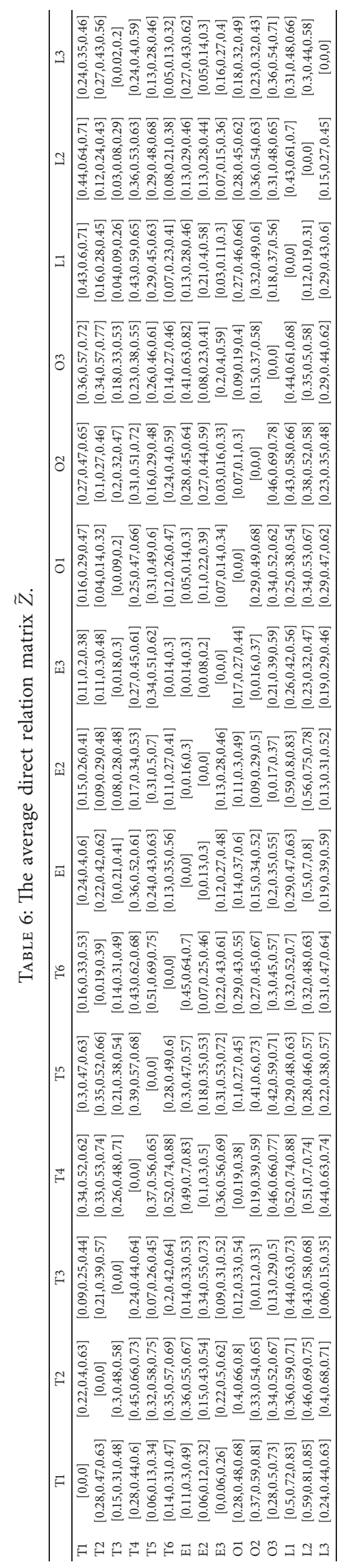




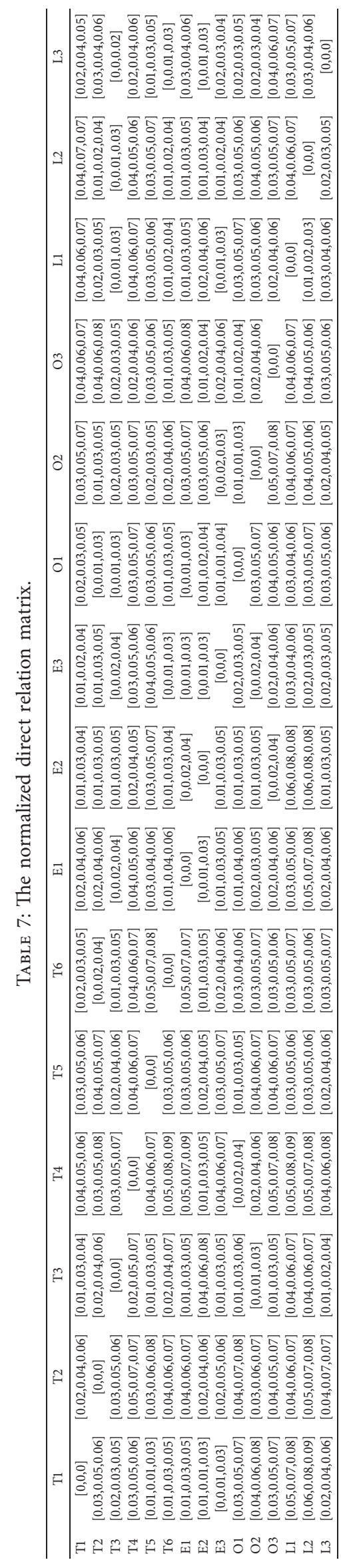




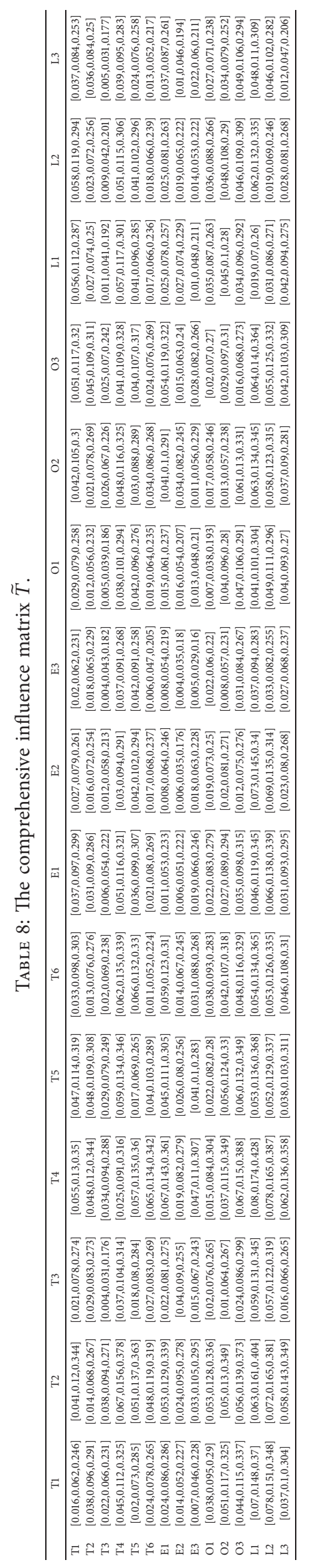


TABLE 9: Calculating table of $\widetilde{D}_{i}-\widetilde{R}_{i}, \widetilde{D}_{i}+\widetilde{R}_{i}, \widetilde{D}_{i}, \widetilde{R}_{i}$, and $\widetilde{w}_{z}$.

\begin{tabular}{lccccc}
\hline Challenge & $\widetilde{D}_{i}$ & $\widetilde{R}_{i}$ & $\widetilde{D}_{i}+\widetilde{R}_{i}$ & $\widetilde{D}_{i}-\widetilde{R}_{i}$ & $\widetilde{w}_{z}$ \\
\hline T1 & {$[0.57,1.46,4.34]$} & {$[0.53,1.4,4.36]$} & {$[1.1,2.85,8.7]$} & {$[0.04,0.06,-0.02]$} & {$[0.07,0.07,0.07]$} \\
T2 & {$[0.42,1.25,4.1]$} & {$[0.72,1.89,5.04]$} & {$[1.14,3.14,9.14]$} & {$[-0.3,-0.64,-0.95]$} & {$[0.08,0.08,0.07]$} \\
T3 & {$[0.25,0.88,3.29]$} & {$[0.4,1.24,4.12]$} & {$[0.65,2.12,7.42]$} & {$[-0.15,-0.36,-0.83]$} & {$[0.04,0.05,0.06]$} \\
T4 & {$[0.69,1.69,4.74]$} & {$[0.76,1.86,5.16]$} & {$[1.45,3.55,9.9]$} & {$[-0.07,-0.18,-0.43]$} & {$[0.09,0.09,0.08]$} \\
T5 & {$[0.57,1.48,4.47]$} & {$[0.63,1.6,4.6]$} & {$[1.2,3.09,9.06]$} & {$[-0.07,-0.12,-0.13]$} & {$[0.08,0.07,0.07]$} \\
T6 & {$[0.38,1.18,3.88]$} & {$[0.59,1.53,4.47]$} & {$[0.97,2.7,8.35]$} & {$[-0.2,-0.35,-0.59]$} & {$[0.06,0.07,0.07]$} \\
E1 & {$[0.49,1.37,4.21]$} & {$[0.45,1.32,4.27]$} & {$[0.94,2.7,8.48]$} & {$[0.05,0.05,-0.07]$} & {$[0.06,0.06,0.07]$} \\
E2 & {$[0.27,0.97,3.45]$} & {$[0.39,1.22,3.92]$} & {$[0.67,2.19,7.37]$} & {$[-0.12,-0.25,-0.47]$} & {$[0.04,0.05,0.06]$} \\
E3 & {$[0,1.02,3.61]$} & {$[0,0.96,3.43]$} & {$[0,1.99,7.03]$} & {$[0.01,0.06,0.18]$} & {$[0,0.05,0.06]$} \\
O1 & {$[0.39,1.19,3.98]$} & {$[0.41,1.14,3.77]$} & {$[0.8,2.33,7.75]$} & {$[-0.02,0.04,0.21]$} & {$[0.05,0.06,0.06]$} \\
O2 & {$[0.51,1.42,4.39]$} & {$[0.54,1.37,4.2]$} & {$[1.05,2.79,8.58]$} & {$[-0.03,0.05,0.19]$} & {$[0.07,0.07,0.07]$} \\
O3 & {$[0.63,1.61,4.72]$} & {$[0.55,1.45,4.47]$} & {$[1.18,3.06,9.19]$} & {$[0.08,0.15,0.25]$} & {$[0.08,0.07,0.07]$} \\
L1 & {$[0.83,1.93,5.17]$} & {$[0.48,1.24,3.89]$} & {$[1.31,3.17,9.06]$} & {$[0.35,0.69,1.28]$} & {$[0.09,0.08,0.07]$} \\
L2 & {$[0.82,1.83,4.76]$} & {$[0.5,1.3,4.01]$} & {$[1.31,3.13,8.77]$} & {$[0.32,0.53,0.74]$} & {$[0.09,0.08,0.07]$} \\
L3 & {$[0.54,1.41,4.31]$} & {$[0.44,1.13,3.69]$} & {$[0.98,2.54,7.99]$} & {$[0.1,0.28,0.62]$} & {$[0.06,0.06,0.06]$} \\
\hline
\end{tabular}

TABLE 10: Calculating table of $D_{i}^{\text {def }}, R_{i}^{\text {def }},\left(\widetilde{D}_{i}+\widetilde{R}_{i}\right)^{\text {def }},\left(\widetilde{D}_{i}-\widetilde{R}_{i}\right)^{\text {def }}$, and $w_{z}^{\text {def }}$.

\begin{tabular}{lllccc}
\hline Challenge & $D_{i}^{\text {def }}$ & $R_{i}^{\text {def }}$ & $\left(\widetilde{D}_{i}+\widetilde{R}_{i}\right)^{\text {def }}$ & $\left(\widetilde{D}_{i}-\widetilde{R}_{i}\right)^{\text {def }}$ & Influence \\
\hline T1 & 1.92 & 1.96 & 3.88 & 0.04 & $w_{z}^{\text {def }}$ \\
T2 & 2.39 & 1.75 & 4.14 & -0.63 & Influencing \\
T3 & 1.75 & 1.32 & 3.08 & -0.43 & Influenced \\
T4 & 2.41 & 2.20 & 4.61 & -0.21 & Influenced \\
T5 & 2.11 & 2.00 & 4.11 & -0.11 & Influenced \\
T6 & 2.03 & 1.65 & 3.68 & -0.37 & Influenced \\
E1 & 1.84 & 1.86 & 3.70 & 0.02 & Influenced \\
E2 & 1.69 & 1.42 & 3.11 & -0.27 & Influencing \\
E3 & 1.41 & 1.49 & 2.90 & 0.08 & Influenced \\
O1 & 1.62 & 1.69 & 3.30 & 0.075556 & 0.06516 \\
O2 & 1.87 & 1.93 & 3.80 & 0.07 & 0.064211 \\
O3 & 1.98 & 2.14 & 4.12 & 0.16 & Influencing \\
L1 & 1.71 & 2.46 & 4.17 & 0.75 & Influencing \\
L2 & 1.78 & 2.31 & 4.09 & 0.53 & Influencing \\
L3 & 1.60 & 1.91 & 3.51 & 0.32 & Influencing \\
\hline
\end{tabular}

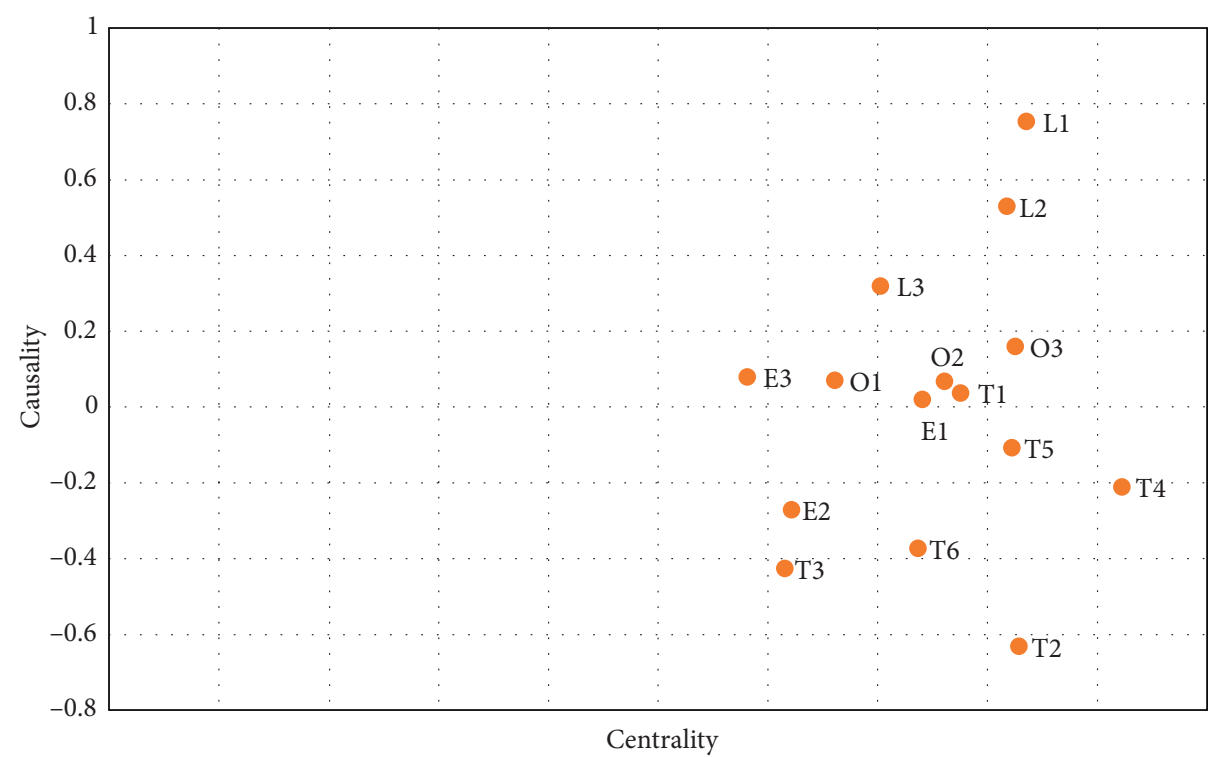

FIgURE 4: The causal diagram among various challenges. 
TABLe 11: The overall defuzzy influence matrix $H$.

\begin{tabular}{|c|c|c|c|c|c|c|c|c|c|c|c|c|c|c|c|}
\hline & $\mathrm{T} 1$ & $\mathrm{~T} 2$ & T3 & $\mathrm{T} 4$ & T5 & T6 & E1 & E2 & E3 & $\mathrm{O} 1$ & $\mathrm{O} 2$ & $\mathrm{O} 3$ & L1 & L2 & L3 \\
\hline $\mathrm{T} 1$ & 0.10 & 0.16 & 0.11 & 0.17 & 0.15 & 0.13 & 0.13 & 0.11 & 0.1 & 0.11 & 0.12 & 0.15 & 0.14 & 0.15 & 0.11 \\
\hline $\mathrm{T} 2$ & 0.13 & 0.1 & 0.15 & 0.16 & 0.14 & 0.11 & 0.12 & 0.1 & 0.09 & 0.089 & 0.111 & 0.143 & 0.106 & 0.105 & 0.113 \\
\hline T3 & 0.095 & 0.124 & 0.060 & 0.127 & 0.108 & 0.099 & 0.083 & .085 & 0.067 & .067 & .096 & .101 & .071 & .073 & 0.061 \\
\hline $\mathrm{T} 4$ & 0.148 & 0.189 & 0.139 & 0.130 & 0.168 & 57 & & & & & & & & & .127 \\
\hline T5 & 0.113 & 0.172 & 0.115 & 0.171 & 0.104 & 0.164 & 0.135 & .134 & 0.120 & 0.127 & 0.123 & 0.142 & 0.129 & 0.135 & 0.108 \\
\hline T6 & 0.111 & 0.151 & 0.115 & 0.168 & 0.133 & 0.084 & 0.112 & 0.097 & 0.076 & 0.095 & 0.1 & 0.111 & 0.096 & 0.097 & 0.083 \\
\hline E1 & 0.120 & 0.162 & 0.114 & 0.178 & 0.143 & 0.153 & 087 & .095 & 0.083 & 0.093 & 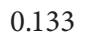 & 3 & 0.109 & 2 & 0.118 \\
\hline E2 & 0.086 & 0.122 & 0.118 & 0.115 & 0.110 & 0.098 & 82 & 62 & 0.063 & 0.082 & 10 & 95 & 00 & 92 & 0.073 \\
\hline E3 & 0.082 & 0.134 & 0.098 & 0.143 & 0.130 & 0.118 & 0.099 & 0.092 & 0.056 & 0.079 & & & 0.079 & 0.085 & 0.09 \\
\hline $\mathrm{O} 1$ & 0.129 & 0.161 & 0.109 & 0.121 & 0.116 & 0.126 & 0.116 & 0.103 & 0.090 & 0.068 & 0.094 & 0.107 & 0.118 & 0.119 & 0.1 \\
\hline $\mathrm{O} 2$ & 0.152 & 0.164 & 0.101 & 0.154 & 0.158 & 0.143 & 0.124 & 0.113 & 0.088 & 0.127 & 0.091 & 0.133 & 0.131 & 0.138 & 0.11 \\
\hline $\mathrm{O} 3$ & 0.152 & 0.176 & 0.123 & 0.188 & 0.168 & 0.152 & 0.136 & 20 & 0.116 & 7 & 2 & 6 & 0.129 & 0.143 & 0.14 \\
\hline L1 & 0.183 & 0.197 & 0.166 & 0.214 & 0.173 & 0.171 & 0.157 & 0.175 & 0.126 & 0.136 & 0.168 & 0.176 & 0.104 & 0.165 & 0.14 \\
\hline L2 & 0.181 & 0.196 & 0.154 & 0.198 & 0.161 & 0.160 & 0.169 & 0.163 & 0.113 & 0.141 & 0.154 & 0.159 & 0.118 & 0.100 & 0.13 \\
\hline L3 & 0.14 & 0.17 & 0.1 & 0.17 & 0.14 & 0.14 & 0.13 & 0.11 & 0.1 & 0.12 & 0.12 & 0.14 & 0.13 & 0.11 & 0.08 \\
\hline
\end{tabular}

TABle 12: Reachability matrix $K$.

\begin{tabular}{lccccccccccccccc}
\hline & T1 & T2 & T3 & T4 & T5 & T6 & E1 & E2 & E3 & O1 & O2 & O3 & L1 & L2 & L3 \\
\hline T1 & 1 & 1 & 0 & 1 & 1 & 1 & 1 & 0 & 0 & 0 & 1 & 1 & 1 & 1 & 0 \\
T2 & 1 & 1 & 0 & 1 & 1 & 0 & 0 & 0 & 0 & 0 & 0 & 1 & 0 & 0 & 0 \\
T3 & 0 & 0 & 1 & 1 & 0 & 0 & 0 & 0 & 0 & 0 & 0 & 0 & 0 & 0 & 0 \\
T4 & 1 & 1 & 1 & 1 & 1 & 1 & 1 & 1 & 0 & 1 & 1 & 1 & 1 & 1 & 1 \\
T5 & 0 & 1 & 0 & 1 & 1 & 1 & 1 & 1 & 0 & 1 & 0 & 1 & 1 & 1 & 0 \\
T6 & 0 & 1 & 0 & 1 & 1 & 1 & 0 & 0 & 0 & 0 & 0 & 0 & 0 & 0 & 0 \\
E1 & 0 & 1 & 0 & 1 & 1 & 1 & 1 & 0 & 0 & 0 & 1 & 1 & 0 & 0 & 0 \\
E2 & 0 & 0 & 0 & 0 & 0 & 0 & 0 & 1 & 0 & 0 & 0 & 0 & 0 & 0 & 0 \\
E3 & 0 & 1 & 0 & 1 & 1 & 0 & 0 & 0 & 1 & 0 & 0 & 0 & 0 & 0 & 0 \\
O1 & 1 & 1 & 0 & 0 & 0 & 1 & 0 & 0 & 0 & 1 & 0 & 0 & 0 & 0 & 0 \\
O2 & 1 & 1 & 0 & 1 & 1 & 1 & 1 & 0 & 0 & 1 & 1 & 1 & 1 & 1 \\
O3 & 1 & 1 & 0 & 1 & 1 & 1 & 1 & 0 & 0 & 1 & 1 & 1 & 1 & 1 \\
L1 & 1 & 1 & 1 & 1 & 1 & 1 & 1 & 1 & 1 & 1 & 1 & 1 & 1 \\
L2 & 1 & 1 & 1 & 1 & 1 & 1 & 1 & 1 & 0 & 1 & 1 & 1 & 0 \\
L3 & 1 & 1 & 0 & 1 & 1 & 1 & 1 & 0 & 0 & 0 & 0 & 1 & 1 \\
\hline
\end{tabular}

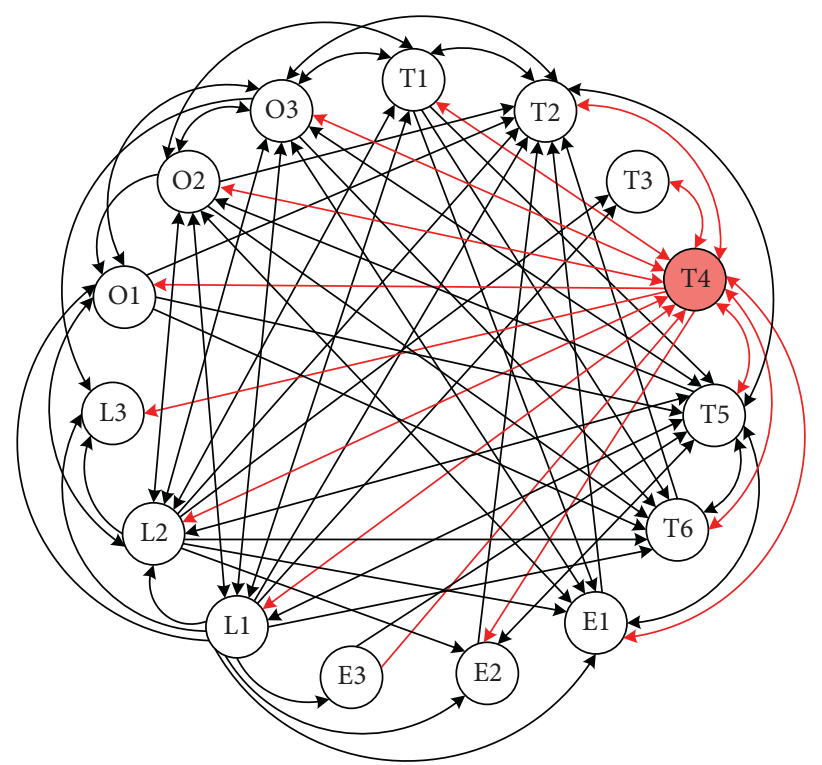

FIgURE 5: The initial diagram among various challenges. 
TABLE 13: Reachable, antecedent sets, and their joint set.

\begin{tabular}{|c|c|c|c|c|}
\hline Challenge & $R_{i}$ & $S_{i}$ & $R_{i} \cap S_{i}$ & Level \\
\hline $\mathrm{T} 1$ & T1, T2, T4, T5, T6, E1, O2, O3, L1, L2 & $\mathrm{T} 1, \mathrm{~T} 2, \mathrm{~T} 4, \mathrm{O} 1, \mathrm{O} 2, \mathrm{O} 3, \mathrm{~L} 1, \mathrm{~L} 2, \mathrm{~L} 3, \mathrm{~T} 1$ & $\mathrm{~T} 1, \mathrm{~T} 2, \mathrm{~T} 4, \mathrm{O} 2, \mathrm{O} 3, \mathrm{~L} 1, \mathrm{~L} 2$ & 3 \\
\hline $\mathrm{T} 2$ & $\mathrm{~T} 1, \mathrm{~T} 2, \mathrm{~T} 4, \mathrm{~T} 5, \mathrm{O} 3$ & $\begin{array}{c}\mathrm{T} 1, \mathrm{~T} 2, \mathrm{~T} 4, \mathrm{~T} 5, \mathrm{~T} 6, \mathrm{E} 1, \mathrm{E} 3, \mathrm{O} 1, \mathrm{O} 2, \\
\mathrm{O} 3, \mathrm{~L} 1, \mathrm{~L} 2, \mathrm{~L} 3\end{array}$ & T1, T2, T4, T5, O3 & 1 \\
\hline T3 & T3, T4 & $\mathrm{T} 3, \mathrm{~T} 4, \mathrm{~L} 1, \mathrm{~L} 2$ & $\mathrm{~T} 3, \mathrm{~T} 4$ & 1 \\
\hline $\mathrm{T} 4$ & $\begin{array}{c}\text { T1, T2, T3, T4, T5, T6, E1, E2, O1, O2, O3, } \\
\text { L1, L2, L3 }\end{array}$ & $\begin{array}{c}\mathrm{T} 1, \mathrm{~T} 2, \mathrm{~T} 3, \mathrm{~T} 4, \mathrm{~T} 5, \mathrm{~T} 6, \mathrm{E} 1, \mathrm{E} 3, \mathrm{O} 2, \mathrm{O} 3, \\
\mathrm{~L} 1, \mathrm{~L} 2, \mathrm{~L} 3\end{array}$ & $\begin{array}{c}\mathrm{T} 1, \mathrm{~T} 2, \mathrm{~T} 3, \mathrm{~T} 4, \mathrm{~T} 5, \mathrm{~T} 6, \mathrm{E} 1, \mathrm{O} 2, \mathrm{O} 3, \\
\mathrm{~L} 1, \mathrm{~L} 2, \mathrm{~L} 3\end{array}$ & 3 \\
\hline T5 & T2, T4, T5, T6, E1, E2, O1, O3, L1, L2, L3 & $\begin{array}{c}\mathrm{T} 1, \mathrm{~T} 2, \mathrm{~T} 4, \mathrm{~T} 5, \mathrm{~T} 6, \mathrm{E} 1, \mathrm{E} 3, \mathrm{O} 2, \mathrm{O} 3, \mathrm{~L} 1, \\
\mathrm{~L} 2, \mathrm{~L} 3\end{array}$ & T2, T4, T5, T6, E1, O3, L1, L2 & 2 \\
\hline T6 & T2, T4, T5, T6 & $\begin{array}{c}\mathrm{T} 1, \mathrm{~T} 4, \mathrm{~T} 5, \mathrm{~T} 6, \mathrm{E} 1, \mathrm{O} 1, \mathrm{O} 2, \mathrm{O} 3, \mathrm{~L} 1, \mathrm{~L} 2, \\
\mathrm{~L} 3\end{array}$ & T4, T5, T6 & 1 \\
\hline E1 & $\mathrm{T} 2, \mathrm{~T} 4, \mathrm{~T} 5, \mathrm{~T} 6, \mathrm{E} 1, \mathrm{O} 2, \mathrm{O} 3$ & T1, T4, T5, E1, O2, O3, L1, L2, L3 & $\mathrm{T} 4, \mathrm{~T} 5, \mathrm{O} 2, \mathrm{O} 3, \mathrm{E} 1$ & 1 \\
\hline E2 & E2 & T4, T5, E2, L1, L2 & E2 & 1 \\
\hline E3 & $\mathrm{T} 2, \mathrm{~T} 4, \mathrm{~T} 5, \mathrm{E} 3$ & $\mathrm{E} 3, \mathrm{~L} 1$ & E3 & 3 \\
\hline $\mathrm{O} 1$ & $\mathrm{~T} 1, \mathrm{~T} 2, \mathrm{~T} 6, \mathrm{O} 1$ & T4, T5, O1, O2, O3, L1, L2, L3 & $\mathrm{O} 1$ & 2 \\
\hline $\mathrm{O} 2$ & T1, T2, T4, T5, T6, E1, O1, O2, O3, L1, L2 & T1, T4, E1, O2, O3, L1, L2 & $\mathrm{T} 1, \mathrm{~T} 4, \mathrm{E} 1, \mathrm{O} 2, \mathrm{O}_{3}^{3}$ & 3 \\
\hline $\mathrm{O} 3$ & $\begin{array}{c}\mathrm{T} 1, \mathrm{~T} 2, \mathrm{~T} 4, \mathrm{~T} 5, \mathrm{~T} 6, \mathrm{E} 1, \mathrm{O} 1, \mathrm{O} 2, \mathrm{O} 3, \mathrm{~L} 1, \mathrm{~L} 2, \\
\mathrm{~L} 3\end{array}$ & T1, T2, T4, T5, E1, O2, O3, L1, L2, L3 & $\begin{array}{c}\mathrm{T} 1, \mathrm{~T} 2, \mathrm{~T} 4, \mathrm{~T} 5, \mathrm{E} 1, \mathrm{O} 2, \mathrm{O} 3, \mathrm{~L} 1, \mathrm{~L} 2, \\
\mathrm{~L} 3\end{array}$ & 3 \\
\hline L1 & $\begin{array}{c}\mathrm{T} 1, \mathrm{~T} 2, \mathrm{~T} 3, \mathrm{~T} 4, \mathrm{~T} 5, \mathrm{~T} 6, \mathrm{E} 1, \mathrm{E} 2, \mathrm{E} 3, \mathrm{O} 1, \mathrm{O} 2, \\
\mathrm{O} 3, \mathrm{~L} 1, \mathrm{~L} 2, \mathrm{~L} 3\end{array}$ & T1, T4, T5, O2, O3, L1, L3 & T1, T4, T5, O2, O3, L1, L3 & 4 \\
\hline $\mathrm{L} 2$ & $\begin{array}{c}\text { T1, T2, T3, T4, T5, T6, E1, E2, O1, O2, O3, } \\
\text { L2, L3 }\end{array}$ & $\mathrm{T} 1, \mathrm{~T} 4, \mathrm{~T} 5, \mathrm{O} 2, \mathrm{O} 3, \mathrm{~L} 1, \mathrm{~L} 2$ & $\mathrm{~T} 1, \mathrm{~T} 4, \mathrm{~T} 5, \mathrm{O} 2, \mathrm{O} 3, \mathrm{~L} 2$ & 4 \\
\hline L3 & T1, T2, T4, T5, T6, E1, O3, L1, L3 & T4, O3, L1, L2, L3 & T4, O3, L1, L3 & 3 \\
\hline
\end{tabular}

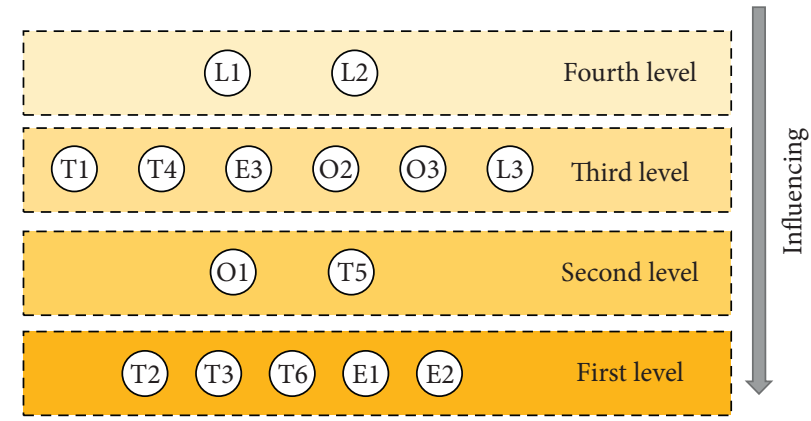

FIgURE 6: The hierarchical network model among the challenges.

interaction and teamwork, absence of BIM infrastructure, having a negative attitude, sanctions, and reluctance to use all people involved are among influenced challenges. It means that teamwork and workforce quality are influenced, and if upper levels do not function well, it would affect the quality of work and the attitude of people involved.

These results to some extent affirm fuzzy Z-number DEMATEL results and emphasize the importance of these challenges. The driving and dependence power diagram constructed on the basis of MICMAC analysis is shown in Figure 7.

As shown in the MICMAC table, in this case, E3, T3, and E2 are autonomous challenges and O1 has weak driving and dependence power. Dependent challenges are T2 and T6. They have very weak driving power and strong dependence. E1 is between dependence and linkage challenges. Linkage challenges have strong driving and also strong dependence. $\mathrm{T} 1, \mathrm{~T} 5, \mathrm{O} 3$, and $\mathrm{T} 4$ are introduced as linkage challenges. L2, O2, and L3 belong to independent challenges. These challenges have less dependence and stronger driving.

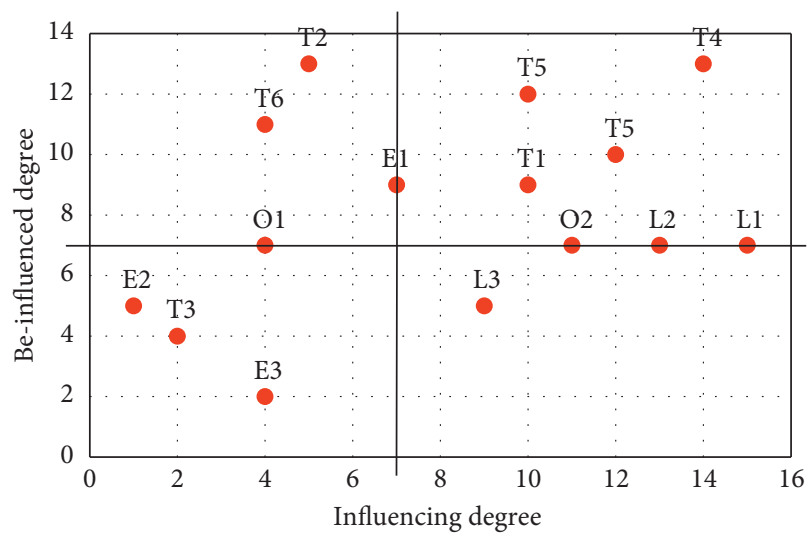

FIgURE 7: MICMAC analysis.

\section{Discussion}

In the previous section, following the methods used, the results were also presented. This section intends to analyze the results and provide new information for these analyses. 


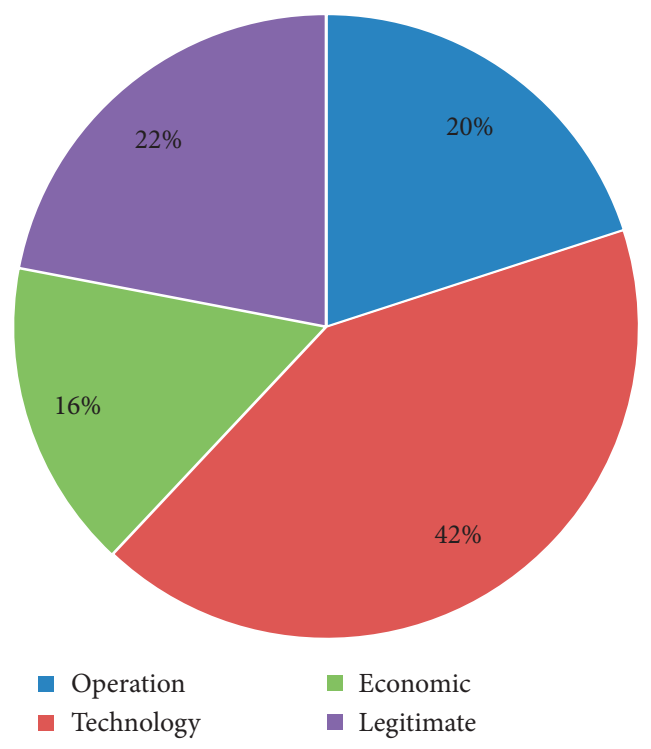

FIgURE 8: Portion of each category.

\begin{tabular}{|c|c|c|}
\hline Challenge & $\left(\tilde{D}_{i}-\tilde{R}_{i}\right)^{\text {def }}$ & Influence \\
\hline T2 & -0.63 & Influenced \\
\hline T3 & -0.43 & Influenced \\
\hline T6 & -0.37 & Influenced \\
\hline E3 & 0.08 & Influencing \\
\hline O1 & 0.07 & Influencing \\
\hline O2 & 0.07 & Influencing \\
\hline L1 & 0.75 & Influencing \\
\hline
\end{tabular}

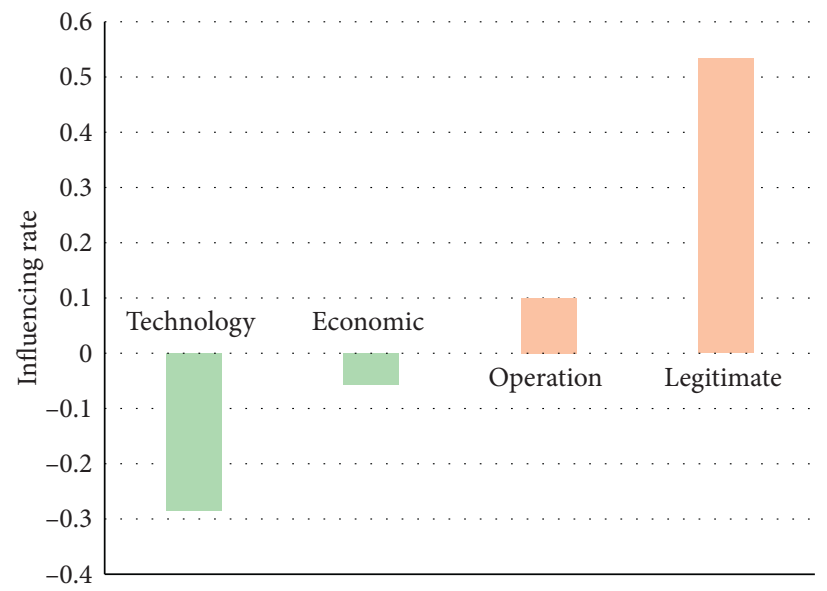

FIGURE 9: General state of each category.

The total weight of each category is shown using a pie chart in Figure 8. Clearly, technology challenges carry a lot of weight (42\%), with legitimate (22\%), operational (20\%), and economic (16\%) challenges in the next categories. In this case, it is clear that countries must first pay more attention to the technology category challenges, prepare the appropriate infrastructures, and train experts to exploit them. Upstream organization or government cooperation and support also plays an imperative role in the successful implementation of building information modeling.

Table 10 shows that the most influenced challenges are technological challenges, and the most Influential challenges are of all three categories: economic, operational, and legal. For this reason, the following diagram is given to show the general status of each category.

As it is clear in Figure 9, generally speaking, the technological and economic categories are more likely to be 


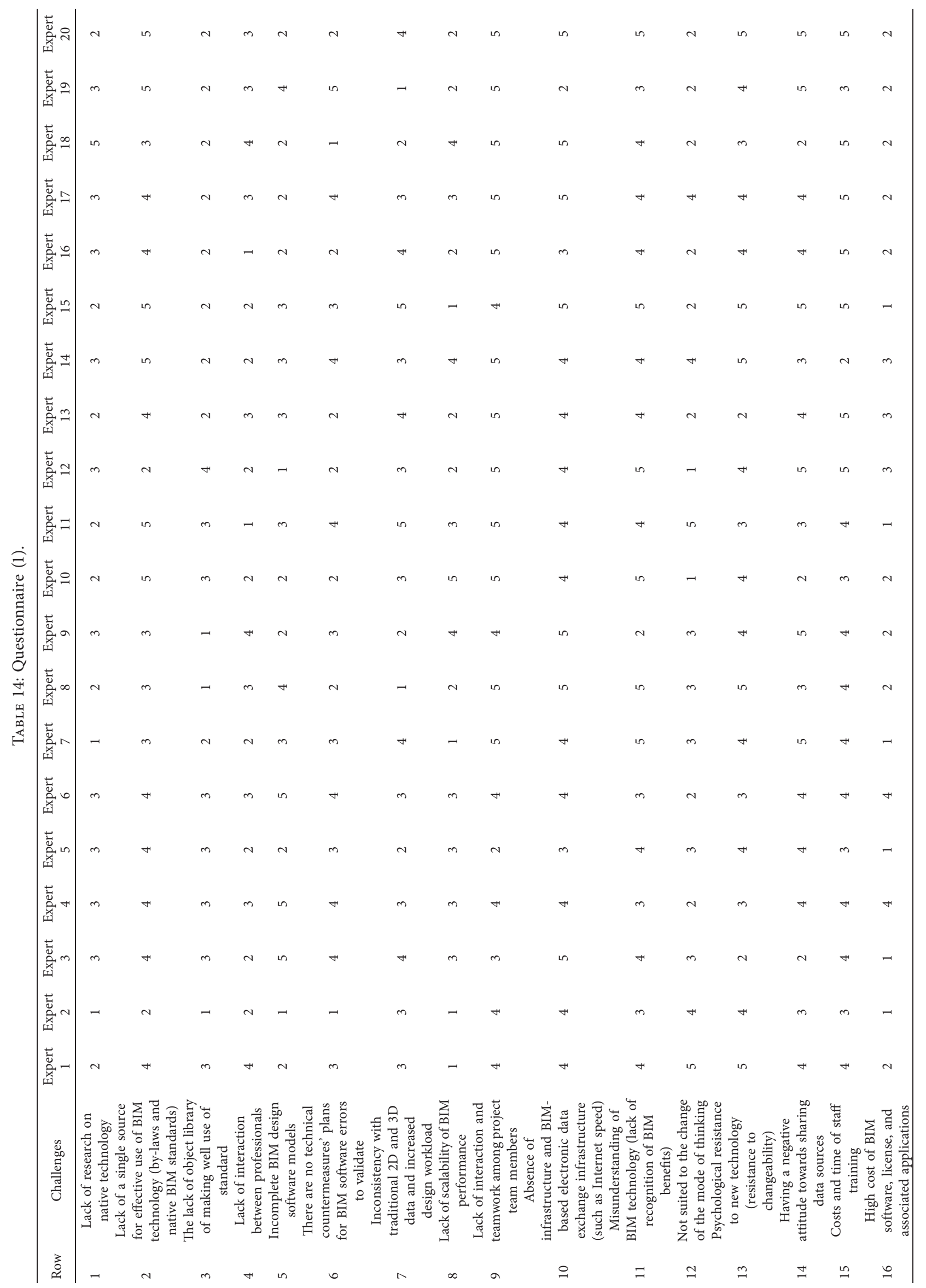




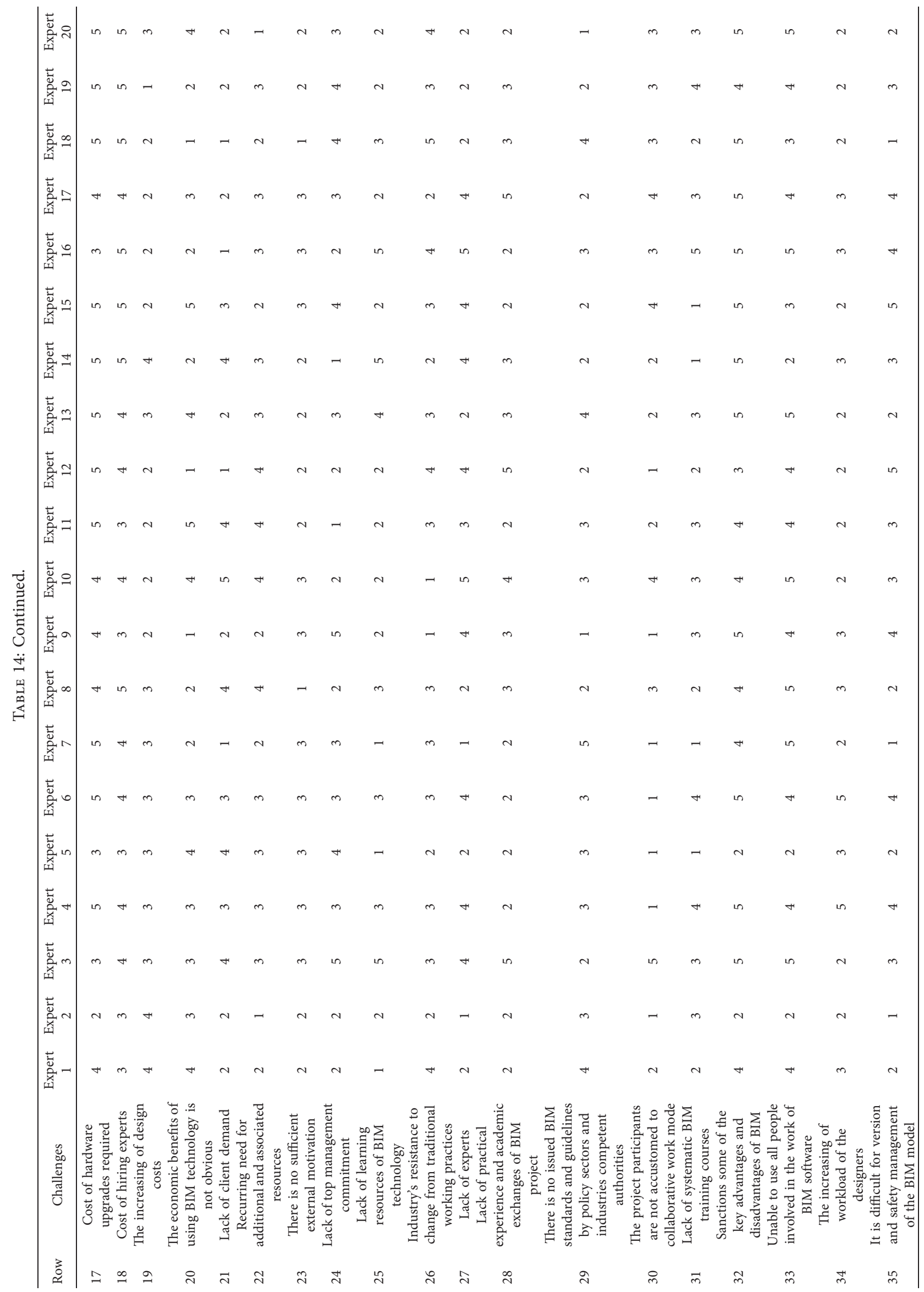




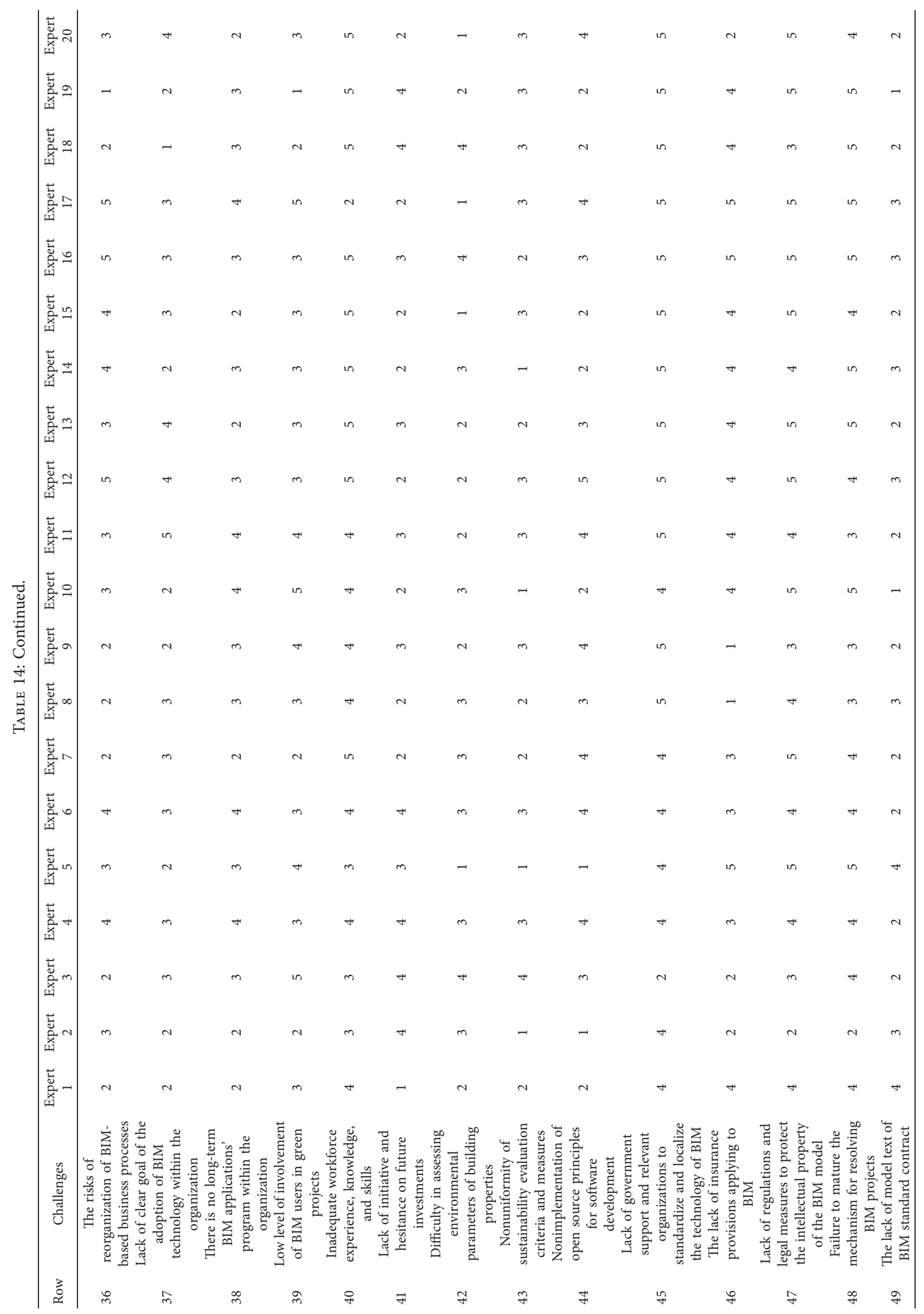


TABLE 15: Questionnaire (2).

\begin{tabular}{|c|c|c|c|c|c|c|c|c|c|c|c|c|c|c|c|}
\hline L3 & $\mathrm{L} 2$ & L1 & E3 & E2 & E1 & $\mathrm{O} 3$ & $\mathrm{O} 2$ & $\mathrm{O} 1$ & T6 & T5 & $\mathrm{T} 4$ & T3 & $\mathrm{T} 2$ & $\mathrm{~T} 1$ & \\
\hline NO-L & VH-C & H-ML & L-M & NO-M & L-ML & NO-M & NO-FI & NO-C & VL-M & VL-U & NO-FI & H-W & NO-C & $*$ & $\mathrm{~T} 1$ \\
\hline $\mathrm{L}-\mathrm{C}$ & NO-W & NO-L & $\begin{array}{l}\text { VL- } \\
\text { ML }\end{array}$ & VL-C & $\mathrm{NO}-\mathrm{U}$ & L-M & VL-FI & L-ML & VL-M & $\mathrm{H}-\mathrm{U}$ & L-FI & L-W & $*$ & L-FI & $\mathrm{T} 2$ \\
\hline NO-L & L-W & L-M & $\mathrm{NO}-\mathrm{U}$ & NO-C & $\begin{array}{l}\text { NO- } \\
\text { ML }\end{array}$ & VL-W & L-M & VL-FI & $\mathrm{H}-\mathrm{U}$ & L-ML & VL-M & $*$ & L-U & L-ML & T3 \\
\hline NO-L & H-W & VH-C & L-M & VL-FI & H-ML & $\mathrm{H}-\mathrm{L}$ & $\mathrm{L}-\mathrm{C}$ & VL-U & H-W & L-ML & $*$ & L-ML & VH-C & $\mathrm{L}-\mathrm{U}$ & $\mathrm{T} 4$ \\
\hline NO-L & H-W & L-M & $\begin{array}{l}\text { VL- } \\
\text { ML }\end{array}$ & NO-C & $\mathrm{L}-\mathrm{U}$ & L-M & L-M & VL-C & H-FI & $*$ & $\mathrm{~L}-\mathrm{U}$ & VL-M & H-L & $\mathrm{NO}-\mathrm{C}$ & T5 \\
\hline NO-L & VL-U & VL-W & $\mathrm{NO}-\mathrm{U}$ & NO-C & L-ML & VL-W & VL-FI & VL-C & * & VL-U & $\mathrm{H}-\mathrm{C}$ & VL-M & $\mathrm{H}-\mathrm{L}$ & L-FI & T6 \\
\hline NO-L & VL-U & VL-W & $\mathrm{H}-\mathrm{C}$ & NO-M & $\mathrm{L}-\mathrm{U}$ & VL-M & VL-FI & * & VL-M & VL-U & $\mathrm{H}-\mathrm{C}$ & L-ML & VL-W & VL-C & $\mathrm{O} 1$ \\
\hline NO-L & L-W & L-M & $\mathrm{NO}-\mathrm{U}$ & NO-L & $\begin{array}{l}\text { NO- } \\
\text { ML }\end{array}$ & NO-M & $*$ & $\mathrm{NO}-\mathrm{C}$ & NO-L & L-ML & VL-M & VL-M & $\mathrm{L}-\mathrm{U}$ & $\mathrm{NO}-\mathrm{C}$ & $\mathrm{O} 2$ \\
\hline NO-L & VL-U & L-M & L-M & $\begin{array}{l}\text { VL- } \\
\text { ML }\end{array}$ & NO-C & * & L-U & NO-C & VL-M & L-ML & VH-W & L-ML & $\mathrm{L}-\mathrm{U}$ & NO-M & $\mathrm{O} 3$ \\
\hline NO-L & L-W & L-M & $\begin{array}{l}\text { VL- } \\
\text { ML }\end{array}$ & NO-M & $*$ & H-L & L-FI & VL-L & VL-M & VL-U & VL-M & VL-M & $\mathrm{H}-\mathrm{L}$ & L-ML & E1 \\
\hline NO-L & VL-U & L-M & $\begin{array}{l}\text { VL- } \\
\text { ML }\end{array}$ & $*$ & L-ML & NO-M & L-L & L-ML & VL-M & VL-U & VL-M & $\mathrm{NO}-\mathrm{C}$ & $\mathrm{L}-\mathrm{U}$ & VL-C & E2 \\
\hline NO-L & VL-U & VL-W & * & $\begin{array}{l}\text { VL- } \\
\text { ML }\end{array}$ & $\begin{array}{l}\text { NO- } \\
\text { ML }\end{array}$ & NO-M & VL-FI & $\mathrm{NO}-\mathrm{C}$ & NO-L & NO-W & VH-W & $\mathrm{NO}-\mathrm{C}$ & $\mathrm{L}-\mathrm{U}$ & $-M L$ & E3 \\
\hline NO-L & L-W & * & $\mathrm{NO}-\mathrm{U}$ & $\begin{array}{l}\mathrm{NO}- \\
\mathrm{ML}\end{array}$ & NO-W & VL-M & VH-L & VL-W & VL-M & VL-U & $\mathrm{H}-\mathrm{C}$ & VL-M & $\mathrm{L}-\mathrm{U}$ & H-ML & L1 \\
\hline NO-L & * & NO-L & $\mathrm{NO}-\mathrm{U}$ & $\begin{array}{l}\text { NO- } \\
\text { ML }\end{array}$ & VL-M & NO-M & VH-L & VH-C & VL-M & $\mathrm{L}-\mathrm{U}$ & VH-W & $\mathrm{JO}-\mathrm{C}$ & IH-C & $-M L$ & L2 \\
\hline * & NO-W & NO-L & $\mathrm{NO}-\mathrm{U}$ & $\begin{array}{l}\text { NO- } \\
\text { ML }\end{array}$ & NO-L & NO-M & L-ML & L-ML & NO-FI & NO-W & L-FI & $\mathrm{NO}-\mathrm{C}$ & VH-C & VL-C & L3 \\
\hline \multicolumn{16}{|c|}{ Expert 1} \\
\hline NO-L & $\begin{array}{l}\text { VL- } \\
\text { ML }\end{array}$ & NO-FI & $\begin{array}{l}\text { VL- } \\
\text { ML }\end{array}$ & VL-L & NO-FI & NO-M & NO-M & $\mathrm{NO}-\mathrm{C}$ & NO-FI & NO-FI & VL-W & VL-L & VL-L & * & $\mathrm{T} 1$ \\
\hline VL-U & NO-FI & NO-W & $\begin{array}{l}\text { VL- } \\
\text { ML }\end{array}$ & VL-L & VL-C & L-FI & $\begin{array}{l}\text { VL- } \\
\text { ML }\end{array}$ & L-U & VL-M & $\mathrm{H}-\mathrm{U}$ & H-ML & $\mathrm{L}-\mathrm{C}$ & $*$ & L-FI & $\mathrm{T} 2$ \\
\hline NO-L & NO-M & NO-W & NO-M & $\mathrm{NO}-\mathrm{U}$ & NO-C & VL-M & VL-FI & VL-C & VL-U & L-L & L-ML & * & H-W & $\mathrm{L}-\mathrm{U}$ & T3 \\
\hline H-M & L-FI & $\mathrm{NO}-\mathrm{U}$ & $\begin{array}{l}\text { NO- } \\
\text { ML }\end{array}$ & L-L & VL-C & VL-W & $\begin{array}{l}\text { VL- } \\
\text { ML }\end{array}$ & L-U & $\begin{array}{l}\text { VH- } \\
\text { ML }\end{array}$ & L-W & * & L-ML & VL-L & $-U$ & $\mathrm{~T} 4$ \\
\hline H-M & $\mathrm{H}-\mathrm{U}$ & NO-W & $\begin{array}{l}\text { VL- } \\
\text { ML }\end{array}$ & NO-U & VL-C & VL-U & L-C & VL-FI & $\begin{array}{l}\text { VH- } \\
\text { ML }\end{array}$ & * & L-ML & L- & $\mathrm{L}-\mathrm{C}$ & $-W$ & T5 \\
\hline NO-L & $\mathrm{H}-\mathrm{U}$ & VL-L & NO-FI & L-L & NO-C & VL-W & VL-U & $\begin{array}{l}\text { VL- } \\
\text { ML }\end{array}$ & $*$ & VL-C & VH-W & H-ML & H-W & VL-U & T6 \\
\hline $\mathrm{L}-\mathrm{U}$ & FI & NO-M & $-\mathrm{L}$ & L-L & $\mathrm{L}-\mathrm{C}$ & $\mathrm{V}$ & $\mathrm{VL}$ & $*$ & $\begin{array}{l}\text { VH- } \\
\text { ML }\end{array}$ & VL-C & H-ML & L-ML & L-C & $-U$ & $\mathrm{O} 1$ \\
\hline NO-L & NO-M & L-M & NO-W & $\mathrm{NO}-\mathrm{U}$ & NO-FI & VL-M & * & VL-L & VL-C & $\mathrm{H}-\mathrm{U}$ & VL-W & VL-L & L-C & NO-W & $\mathrm{O} 2$ \\
\hline VL-U & $\begin{array}{l}\text { NO- } \\
\text { ML }\end{array}$ & $\mathrm{NO}-\mathrm{C}$ & L-W & $\mathrm{NO}-\mathrm{U}$ & $\mathrm{NO}-\mathrm{U}$ & * & $\mathrm{L}-\mathrm{C}$ & $\mathrm{NO}-\mathrm{C}$ & L-M & VL-C & L-ML & VL-L & VL-L & NO-W & $\mathrm{O} 3$ \\
\hline NO-L & NO-U & VL-L & L-W & $\mathrm{NO}-\mathrm{U}$ & * & VL-M & VL-U & VL-C & H-W & VL-C & VL-W & VL-L & H-W & L-M & E1 \\
\hline NO-L & L-FI & NO-M & $\begin{array}{l}\text { VL- } \\
\text { ML }\end{array}$ & $*$ & VL-C & VL-M & L-C & VL-U & H-W & VH-M & L-ML & $\mathrm{NO}-\mathrm{C}$ & H-W & $\mathrm{H}-\mathrm{C}$ & E2 \\
\hline VH-C & $\mathrm{H}-\mathrm{U}$ & VL-L & $*$ & $I$ & VL-C & $\mathrm{H}-\mathrm{C}$ & VL- & H-M & H-W & H-L & $\mathrm{H}-\mathrm{U}$ & $-M L$ & $\mathrm{H}-\mathrm{U}$ & $\mathrm{L}-\mathrm{C}$ & E3 \\
\hline H-M & NO-L & $*$ & & 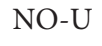 & NO-C & VL-U & VH-FI & $\mathrm{I}$ & H-W & $\mathrm{H}-\mathrm{FI}$ & H-ML & $\mathrm{NO}-\mathrm{U}$ & $\mathrm{H}-\mathrm{M}$ & $\mathrm{L}-\mathrm{C}$ & L1 \\
\hline NO-L & * & $\mathrm{NO}-\mathrm{U}$ & $\begin{array}{l}\text { NO- } \\
\mathrm{ML}\end{array}$ & $\mathrm{NO}-\mathrm{U}$ & H-ML & NO-M & VH-FI & VH-M & NO-L & $\mathrm{H}-\mathrm{U}$ & VH-W & $\begin{array}{c}\text { NO- } \\
\text { ML }\end{array}$ & H-W & VH-L & $\mathrm{L} 2$ \\
\hline * & NO-W & $\begin{array}{l}\text { NO- } \\
\text { ML }\end{array}$ & NO-C & $\mathrm{NO}-\mathrm{U}$ & VL-C & NO-M & $\mathrm{L}-\mathrm{C}$ & L-U & H-W & L-ML & $\mathrm{H}-\mathrm{U}$ & $\begin{array}{l}\text { NO- } \\
\text { ML }\end{array}$ & H-ML & L-L & L3 \\
\hline \multicolumn{16}{|c|}{ Expert 2} \\
\hline $\begin{array}{l}\text { VH- } \\
\text { ML }\end{array}$ & VH-FI & $\mathrm{H}-\mathrm{C}$ & $\mathrm{H}-\mathrm{ML}$ & TIII & -FI & H-L & NC & $-\mathrm{C}$ & L-M & $\begin{array}{l}\mathrm{VH}- \\
\mathrm{ML}\end{array}$ & VH-L & $\mathrm{NO}-\mathrm{U}$ & $\mathrm{L}-\mathrm{C}$ & * & $\mathrm{T} 1$ \\
\hline VH-U & NO-M & NO-W & H-ML & $\begin{array}{l}\mathrm{VH}- \\
\mathrm{ML}\end{array}$ & L-C & $\mathrm{H}-\mathrm{U}$ & $\begin{array}{l}\text { VL- } \\
\text { ML }\end{array}$ & $\mathrm{H}-\mathrm{ML}$ & VL-C & H-W & H-M & $\mathrm{H}-\mathrm{L}$ & * & VL-U & $\mathrm{T} 2$ \\
\hline NO-M & NO-L & $\mathrm{NO}-\mathrm{C}$ & $-W$ & H-FI & VL-U & VL-W & L-M & $\begin{array}{l}\text { VL- } \\
\text { ML }\end{array}$ & $\mathrm{H}-\mathrm{C}$ & L-U & $\begin{array}{l}\text { VL- } \\
\text { ML }\end{array}$ & $*$ & VH-W & $\begin{array}{l}\text { VL- } \\
\text { ML }\end{array}$ & T3 \\
\hline
\end{tabular}


Table 15: Continued.

\begin{tabular}{|c|c|c|c|c|c|c|c|c|c|c|c|c|c|c|c|}
\hline L3 & $\mathrm{L} 2$ & L1 & E3 & E2 & E1 & $\mathrm{O} 3$ & $\mathrm{O} 2$ & $\mathrm{O} 1$ & T6 & T5 & $\mathrm{T} 4$ & $\mathrm{~T} 3$ & $\mathrm{~T} 2$ & $\mathrm{~T} 1$ & \\
\hline H-L & IH-FI & $\mathrm{VH}-\mathrm{U}$ & L-W & H-ML & VH-M & VH-U & H-L & H-ML & VH-U & VH-L & * & L-W & VH-C & $\mathrm{H}-\mathrm{U}$ & T4 \\
\hline L-M & H-FI & $\mathrm{H}-\mathrm{C}$ & H-ML & L-M & VH-M & $\mathrm{H}-\mathrm{C}$ & H-L & H-ML & $\mathrm{H}-\mathrm{C}$ & * & VH-L & $\mathrm{L}-\mathrm{W}$ & H-L & $\begin{array}{l}\text { VL- } \\
\text { ML }\end{array}$ & T5 \\
\hline VL-M & $\mathrm{L}-\mathrm{C}$ & L-W & VL-W & $\begin{array}{l}\text { VH- } \\
\text { ML }\end{array}$ & $\mathrm{H}-\mathrm{FI}$ & VL-W & VH-C & $\begin{array}{l}\text { VL- } \\
\text { ML }\end{array}$ & * & VH-C & $\mathrm{H}-\mathrm{M}$ & $\mathrm{H}-\mathrm{L}$ & $\mathrm{VH}-\mathrm{U}$ & L-M & T6 \\
\hline $\mathrm{H}-\mathrm{L}$ & VL-U & VL-W & VH-M & $\mathrm{H}-\mathrm{C}$ & $\mathrm{H}-\mathrm{U}$ & VL-W & $\begin{array}{l}\text { VL- } \\
\text { ML }\end{array}$ & $*$ & VH-U & VH-W & $\mathrm{H}-\mathrm{M}$ & $\begin{array}{l}\text { VL- } \\
\text { ML }\end{array}$ & $\mathrm{H}-\mathrm{L}$ & L-M & $\mathrm{O} 1$ \\
\hline VL-M & VL-U & VL-W & VL-W & $\begin{array}{l}\text { VH- } \\
\text { ML }\end{array}$ & VL-U & NO-M & $*$ & $\mathrm{NO}-\mathrm{U}$ & $\mathrm{H}-\mathrm{C}$ & $\mathrm{H}-\mathrm{W}$ & $\begin{array}{l}\text { VL- } \\
\text { ML }\end{array}$ & VH-C & $\mathrm{L}-\mathrm{C}$ & NO-FI & $\mathrm{O} 2$ \\
\hline NO-M & NO-M & NO-W & $\mathrm{L}-\mathrm{W}$ & NO-W & $\mathrm{NO}-\mathrm{C}$ & $*$ & L-M & $\begin{array}{l}\text { VL- } \\
\text { ML }\end{array}$ & L-M & $\mathrm{L}-\mathrm{U}$ & $\begin{array}{l}\text { VL- } \\
\text { ML }\end{array}$ & $\begin{array}{l}\text { VL- } \\
\text { ML }\end{array}$ & $\mathrm{L}-\mathrm{C}$ & NO-FI & O3 \\
\hline VH-C & VH-FI & $\mathrm{H}-\mathrm{C}$ & H-ML & H-ML & $*$ & $\mathrm{H}-\mathrm{M}$ & $\mathrm{H}-\mathrm{L}$ & H-ML & $\mathrm{H}-\mathrm{C}$ & $\begin{array}{l}\text { VH- } \\
\text { ML }\end{array}$ & $\begin{array}{l}\text { VL- } \\
\text { ML }\end{array}$ & $\mathrm{H}-\mathrm{L}$ & $\mathrm{H}-\mathrm{L}$ & L-M & E1 \\
\hline H-L & $\mathrm{H}-\mathrm{FI}$ & $\mathrm{H}-\mathrm{C}$ & L-W & $*$ & H-ML & NO-M & L-M & $\mathrm{L}-\mathrm{C}$ & $\mathrm{H}-\mathrm{C}$ & $\begin{array}{l}\text { VH- } \\
\text { ML }\end{array}$ & $\mathrm{H}-\mathrm{M}$ & $\mathrm{NO}-\mathrm{U}$ & VH-W & H-FI & E2 \\
\hline $\mathrm{H}-\mathrm{U}$ & $\mathrm{H}-\mathrm{FI}$ & L-W & $*$ & $\begin{array}{l}\text { VH- } \\
\text { ML }\end{array}$ & VH-M & H-ML & $\begin{array}{l}\text { VL- } \\
\text { ML }\end{array}$ & H-ML & VH-U & $\mathrm{VH}-\mathrm{C}$ & VH-L & $\begin{array}{l}\text { VL- } \\
\text { ML }\end{array}$ & H-L & $\mathrm{H}-\mathrm{M}$ & E3 \\
\hline VH-FI & VH-FI & * & VH-M & VH-L & VH-M & VH-U & VH-C & VH-FI & VH-U & $\begin{array}{l}\text { VH- } \\
\text { ML }\end{array}$ & VH-L & VH-C & VH-W & $\begin{array}{l}\text { VH- } \\
\text { ML }\end{array}$ & L1 \\
\hline VH-C & * & VH-U & VH-M & $\begin{array}{l}\text { VH- } \\
\text { ML }\end{array}$ & VH-M & VH-U & VH-C & VH-FI & VH-U & VH-L & VH-L & VH-C & $\begin{array}{l}\text { VH- } \\
\text { ML }\end{array}$ & $\begin{array}{l}\text { VH- } \\
\text { ML }\end{array}$ & L2 \\
\hline$*$ & H-FI & $\mathrm{H}-\mathrm{C}$ & H-ML & $\mathrm{H}-\mathrm{U}$ & VH-M & H-L & $\begin{array}{l}\text { L-M } \\
\text { Expert }\end{array}$ & $3^{\mathrm{L}-\mathrm{C}}$ & VH-U & $\mathrm{H}-\mathrm{W}$ & VH-L & $\mathrm{NO}-\mathrm{U}$ & VH-C & $\mathrm{H}-\mathrm{U}$ & L3 \\
\hline L-U & $\mathrm{L}-\mathrm{C}$ & $\mathrm{H}-\mathrm{U}$ & $\mathrm{H}-\mathrm{C}$ & $\begin{array}{l}\text { VL- } \\
\text { ML }\end{array}$ & $\begin{array}{l}\mathrm{NO}- \\
\mathrm{ML}\end{array}$ & H-FI & VL-M & $\mathrm{H}-\mathrm{C}$ & VL-W & $\mathrm{H}-\mathrm{C}$ & VH-L & L-U & $\mathrm{H}-\mathrm{FI}$ & * & $\mathrm{T} 1$ \\
\hline L-W & $\mathrm{L}-\mathrm{C}$ & VL-W & $\mathrm{H}-\mathrm{L}$ & $\begin{array}{l}\text { VL- } \\
\text { ML }\end{array}$ & VL-L & VL-C & VL-FI & L-M & VL-W & $\mathrm{H}-\mathrm{FI}$ & $\mathrm{H}-\mathrm{C}$ & VL-W & * & L-ML & $\mathrm{T} 2$ \\
\hline VL-U & $\begin{array}{l}\text { VL- } \\
\text { ML }\end{array}$ & $\mathrm{L}-\mathrm{U}$ & VL-C & VH-W & VL-FI & VL-L & L-W & VL-U & L-ML & $\mathrm{L}-\mathrm{U}$ & L-C & * & $\begin{array}{l}\text { VL- } \\
\text { ML }\end{array}$ & $\mathrm{H}-\mathrm{U}$ & T3 \\
\hline VL-FI & $\mathrm{H}-\mathrm{W}$ & $\mathrm{L}-\mathrm{U}$ & $\mathrm{H}-\mathrm{C}$ & H-ML & VL-M & VL-FI & NO-U & NO-FI & $\begin{array}{l}\text { VL- } \\
\text { ML }\end{array}$ & $\mathrm{H}-\mathrm{L}$ & $*$ & $\mathrm{~L}-\mathrm{C}$ & $\begin{array}{l}\text { VL- } \\
\text { ML }\end{array}$ & H-W & $\mathrm{T} 4$ \\
\hline VL-C & $\begin{array}{l}\text { VL- } \\
\text { ML }\end{array}$ & $\mathrm{H}-\mathrm{U}$ & L-W & H-ML & VH-M & $\mathrm{NO}-\mathrm{C}$ & $\mathrm{NO}-\mathrm{U}$ & NO-FI & VH-U & $*$ & $\begin{array}{l}\text { VL- } \\
\text { ML }\end{array}$ & $-W$ & $\begin{array}{l}\text { VL- } \\
\text { ML }\end{array}$ & $\mathrm{H}-\mathrm{L}$ & T5 \\
\hline VL-C & VL-FI & $\mathrm{L}-\mathrm{U}$ & $\mathrm{H}-\mathrm{C}$ & $\begin{array}{l}\text { VL- } \\
\text { ML }\end{array}$ & $\begin{array}{l}\text { NO- } \\
\text { ML }\end{array}$ & $\mathrm{NO}-\mathrm{C}$ & NO-U & VL-U & $*$ & VL-M & $\mathrm{H}-\mathrm{C}$ & H-L & $\mathrm{L}-\mathrm{W}$ & H-ML & T6 \\
\hline L-C & $\begin{array}{l}\text { VL- } \\
\text { ML }\end{array}$ & $\mathrm{L}-\mathrm{U}$ & $\mathrm{H}-\mathrm{M}$ & $\mathrm{L}-\mathrm{U}$ & VL-M & $\mathrm{NO}-\mathrm{C}$ & $\mathrm{NO}-\mathrm{U}$ & * & $\mathrm{H}-\mathrm{C}$ & L-L & $\mathrm{H}-$ & V & L-W & I-ML & $\mathrm{O} 1$ \\
\hline VL-W & VL-L & $\mathrm{H}-\mathrm{U}$ & VL-C & $\begin{array}{l}\text { VL- } \\
\text { ML }\end{array}$ & $\mathrm{H}-\mathrm{M}$ & $\mathrm{NO}-\mathrm{C}$ & * & VL-U & VL-U & $\mathrm{L}-\mathrm{U}$ & $\begin{array}{l}\text { VL- } \\
\text { ML }\end{array}$ & H-L & $\begin{array}{l}\text { VL- } \\
\text { ML }\end{array}$ & -ML & $\mathrm{O} 2$ \\
\hline VH-C & $\mathrm{L}-\mathrm{C}$ & VL-W & H-W & $\mathrm{L}-\mathrm{U}$ & $\mathrm{L}-\mathrm{C}$ & * & VL-M & $\mathrm{H}-\mathrm{C}$ & L-ML & H-M & VH-L & VL-W & H-FI & VL-M & $\mathrm{O} 3$ \\
\hline VL-M & VL-C & $\mathrm{L}-\mathrm{U}$ & NO-M & $\mathrm{NO}-\mathrm{C}$ & * & H-FI & L-W & $\mathrm{H}-\mathrm{C}$ & VH-U & VL-M & $\begin{array}{l}\text { VL- } \\
\text { ML }\end{array}$ & VL-W & $\begin{array}{l}\text { VL- } \\
\text { ML }\end{array}$ & L-ML & E1 \\
\hline L-U & $-\mathrm{C}$ & VL-W & L-W & * & $-M$ & $\begin{array}{l}\text { VL- } \\
\text { ML }\end{array}$ & $\mathrm{U}$ & VL-U & L-ML & $\mathrm{H}-\mathrm{C}$ & $\begin{array}{l}\text { VL- } \\
\text { ML }\end{array}$ & VL-W & L-W & H-ML & E2 \\
\hline $\begin{array}{l}\text { L-ML } \\
\text { VL-M }\end{array}$ & $\begin{array}{c}\mathrm{H}-\mathrm{W} \\
\mathrm{L}-\mathrm{C}\end{array}$ & $\begin{array}{c}\text { VL-W } \\
*\end{array}$ & $\begin{array}{c}* \\
\mathrm{~L}-\mathrm{W}\end{array}$ & $\begin{array}{l}\text { H-ML } \\
\text { H-ML }\end{array}$ & $\begin{array}{l}\text { VL-M } \\
\text { L-C }\end{array}$ & $\begin{array}{l}\text { VL-C } \\
\text { H-FI }\end{array}$ & $\begin{array}{c}\mathrm{NO}-\mathrm{W} \\
\mathrm{L}-\mathrm{W}\end{array}$ & $\begin{array}{c}\text { NO-FI } \\
\text { L-M }\end{array}$ & $\begin{array}{c}\mathrm{VH}-\mathrm{U} \\
\mathrm{H}-\mathrm{C}\end{array}$ & $\begin{array}{l}\mathrm{H}-\mathrm{M} \\
\mathrm{L}-\mathrm{U}\end{array}$ & $\mathrm{H}-\mathrm{C}$ & $\begin{array}{c}\text { VL-W } \\
\text { H-L }\end{array}$ & $\begin{array}{l}\text { H-FI } \\
\text { H-FI }\end{array}$ & $\begin{array}{l}\text { L-ML } \\
\text { L-ML }\end{array}$ & $\begin{array}{l}\text { E3 } \\
\text { L1 }\end{array}$ \\
\hline L-U & $*$ & VL-W & VL-C & $\mathrm{L}-\mathrm{U}$ & $\mathrm{L}-\mathrm{C}$ & $\begin{array}{l}\mathrm{NO}- \\
\mathrm{ML}\end{array}$ & NO-W & $\mathrm{H}-\mathrm{C}$ & $\mathrm{H}-\mathrm{C}$ & VL-M & $\mathrm{L}-\mathrm{C}$ & H-L & H-FI & VH- & L2 \\
\hline * & VL-FI & $\mathrm{L}-\mathrm{U}$ & $\mathrm{H}-\mathrm{W}$ & $\mathrm{L}-\mathrm{U}$ & $\begin{array}{l}\text { VL- } \\
\text { ML }\end{array}$ & NO-FI & NO-L & L-M & $\mathrm{H}-\mathrm{C}$ & $\mathrm{L}-\mathrm{U}$ & $\mathrm{H}-\mathrm{C}$ & L-ML & H-FI & $\mathrm{H}-\mathrm{L}$ & L3 \\
\hline \multicolumn{16}{|c|}{ Expert 4} \\
\hline VH-U & VH-W & VH-W & VH-FI & VH-C & $\mathrm{L}-\mathrm{U}$ & NO-FI & VL-M & VL-M & L-W & $-\mathrm{C}$ & $\mathrm{H}-\mathrm{L}$ & $\begin{array}{l}\text { VL- } \\
\text { ML }\end{array}$ & H-L & $*$ & $\mathrm{~T} 1$ \\
\hline H-FI & $\mathrm{L}-\mathrm{U}$ & $\mathrm{L}-\mathrm{L}$ & H-ML & $\mathrm{NO}-\mathrm{U}$ & NO-W & VL-FI & $\mathrm{L}-\mathrm{U}$ & L-M & $\begin{array}{l}\text { VL- } \\
\text { ML }\end{array}$ & $\mathrm{H}-\mathrm{C}$ & H-W & H-FI & $*$ & H-ML & $\mathrm{T} 2$ \\
\hline NO-U & NO-W & $\begin{array}{l}\mathrm{NO}- \\
\mathrm{ML}\end{array}$ & H-ML & L-W & VL-U & VL-L & VL-L & $\begin{array}{l}\text { VL- } \\
\text { ML }\end{array}$ & VL-U & $\mathrm{H}-\mathrm{ML}$ & $\mathrm{H}-\mathrm{W}$ & * & VH-C & VL-U & T3 \\
\hline H-ML & VH-M & VH-C & $\mathrm{H}-\mathrm{U}$ & H-L & L-W & $\mathrm{H}-\mathrm{M}$ & L-FI & VH-L & VH-M & NO-U & $*$ & $\mathrm{~L}-\mathrm{U}$ & $\begin{array}{l}\text { VH- } \\
\text { ML }\end{array}$ & H-W & $\mathrm{T} 4$ \\
\hline
\end{tabular}


TABLE 15: Continued.

\begin{tabular}{|c|c|c|c|c|c|c|c|c|c|c|c|c|c|c|c|}
\hline 3 & L2 & L1 & E3 & E2 & E1 & O3 & $\mathrm{O} 2$ & O1 & T6 & T5 & $\mathrm{T} 4$ & T3 & $\mathrm{T} 2$ & T1 & \\
\hline$-U$ & $\mathrm{H}-\mathrm{C}$ & $\mathrm{H}-\mathrm{U}$ & VH-FI & L-W & $\mathrm{H}-\mathrm{M}$ & VH-FI & $\mathrm{H}-\mathrm{L}$ & H-M & VH-M & * & VH-L & $\begin{array}{l}\text { VL- } \\
\text { ML }\end{array}$ & $\mathrm{H}-\mathrm{L}$ & $\mathrm{O}-\mathrm{W}$ & T5 \\
\hline $\mathrm{H} \mathrm{H}-\mathrm{U}$ & L-U & L-L & $\mathrm{H}-\mathrm{C}$ & H-FI & $\begin{array}{l}\text { VL- } \\
\text { ML }\end{array}$ & VL-C & VL-FI & H-M & * & $\mathrm{H}-\mathrm{W}$ & VH-L & $\begin{array}{l}\text { VL- } \\
\text { ML }\end{array}$ & $\mathrm{H}-\mathrm{L}$ & VL-U & T6 \\
\hline $\mathrm{H}-\mathrm{U}$ & $\mathrm{L}-\mathrm{U}$ & L-L & H-ML & H-ML & NO-W & VL-U & VL-W & * & VH-M & VH-W & VH-L & L-U & $\begin{array}{l}\text { VH- } \\
\text { ML }\end{array}$ & VL-U & O1 \\
\hline $\mathrm{NO}-\mathrm{U}$ & VL-M & VL-FI & L-M & $\mathrm{H}-\mathrm{L}$ & VL-C & VL-U & * & VL-M & VL-FI & VL-M & $\mathrm{H}-\mathrm{U}$ & H-FI & L-W & NO-W & $\mathrm{O} 2$ \\
\hline VL-C & $\mathrm{NO}-\mathrm{W}$ & $\begin{array}{l}\text { NO- } \\
\text { ML }\end{array}$ & VL-L & VL-W & NO-W & $*$ & NO-W & VL-U & VL-C & $\mathrm{L}-\mathrm{C}$ & H-M & ML & L-W & NO-W & O3 \\
\hline- U & $\mathrm{H}-\mathrm{C}$ & $\mathrm{H}-\mathrm{U}$ & NO-FI & $\mathrm{NO}-\mathrm{U}$ & * & NO-FI & VL-M & $\begin{array}{l}\text { VL- } \\
\text { ML }\end{array}$ & $\begin{array}{l}\text { NO- } \\
\text { ML }\end{array}$ & VL-M & VL-U & $\begin{array}{l}\text { VL- } \\
\text { ML }\end{array}$ & H-L & H-ML & E1 \\
\hline VH-U & VH-U & $\begin{array}{l}\text { VH- } \\
\text { ML }\end{array}$ & L-M & * & $\mathrm{H}-\mathrm{M}$ & VL-C & $\begin{array}{l}\text { VL- } \\
\text { ML }\end{array}$ & L-M & H-FI & H-ML & $\mathrm{H}-\mathrm{U}$ & ML & $\mathrm{H}-\mathrm{L}$ & $\mathrm{H}-\mathrm{L}$ & E2 \\
\hline H-ML & $\mathrm{H}-\mathrm{C}$ & $\mathrm{H}-\mathrm{U}$ & * & VH-C & VH-M & $\mathrm{L}-\mathrm{U}$ & VL-U & L-M & VH-M & VH-W & $\mathrm{H}-\mathrm{C}$ & H-FI & $\begin{array}{l}\text { VH- } \\
\text { ML }\end{array}$ & L-L & E3 \\
\hline $\mathrm{I}-\mathrm{ML}$ & VH-L & * & VH-FI & VH-C & $\mathrm{H}-\mathrm{M}$ & H-M & VH-L & H-M & H-FI & L-C & VH-L & $\begin{array}{l}\text { VH- } \\
\text { ML }\end{array}$ & H-L & H-M & L1 \\
\hline I-ML & * & $\begin{array}{l}\text { NO- } \\
\text { ML }\end{array}$ & VH-FI & VH-C & $\mathrm{H}-\mathrm{M}$ & $\mathrm{H}-\mathrm{M}$ & VH-L & H-M & H-FI & L-C & VH-L & $\begin{array}{l}\text { VH- } \\
\text { ML }\end{array}$ & $\mathrm{H}-\mathrm{L}$ & VH-M & L2 \\
\hline * & $\mathrm{L}-\mathrm{U}$ & $\mathrm{H}-\mathrm{U}$ & H-ML & VH-C & H-M & L-U & L-ML & H-M & H-FI & L-C & VH-L & ML & L-W & L-L & L3 \\
\hline \multicolumn{16}{|c|}{ Expert 5} \\
\hline M & $\mathrm{I}-\mathrm{U}$ & & & & & - & VH-L & & & & & L & $-\mathrm{M}$ & & $\mathrm{T} 1$ \\
\hline 0 & L-ML & L-W & H-ML & VL-C & NO-FI & VL-L & $\mathrm{H}$ & $\mathrm{H}-\mathrm{V}$ & 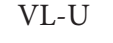 & $\mathrm{H}$ & $L-C$ & L-W & * & VH-L & $\mathrm{T} 2$ \\
\hline $\begin{array}{l}\mathrm{TO}- \\
\mathrm{IL}\end{array}$ & NO-L & NO-U & $\mathrm{H}-\mathrm{W}$ & $\mathrm{L}-\mathrm{U}$ & VL-FI & VL-U & VL-L & VL-C & VL-FI & $\mathrm{H}-\mathrm{U}$ & H-ML & * & $\mathrm{VH}-\mathrm{U}$ & L-W & $\mathrm{T} 3$ \\
\hline H-M & VH-M & VH-C & $\mathrm{H}-\mathrm{U}$ & $\mathrm{H}-\mathrm{L}$ & L-C & $\mathrm{H}-\mathrm{M}$ & L-L & $\begin{array}{l}\mathrm{VH} \\
\mathrm{MI}\end{array}$ & VH-U & VH-W & * & $\mathrm{H}-\mathrm{C}$ & VH-U & $\mathrm{H}-\mathrm{M}$ & $\mathrm{T} 4$ \\
\hline M & H-M & $\mathrm{H}-\mathrm{C}$ & VH-L & $\mathrm{L}-\mathrm{U}$ & H-FI & VH-W & $\mathrm{H}-\mathrm{C}$ & $\mathrm{H}-\mathrm{W}$ & VH-U & $*$ & VH-U & VL-L & $\mathrm{H}-\mathrm{L}$ & NO-W & T5 \\
\hline $\begin{array}{l}\mathrm{O}- \\
\mathrm{L}\end{array}$ & VL-FI & VL-M & NO-L & NO-C & L-C & NO-FI & VL-L & VL-C & * & VL-L & $\mathrm{H}-\mathrm{C}$ & VL-L & $\mathrm{H}-\mathrm{L}$ & L-W & T6 \\
\hline -M & L-ML & L-W & $\mathrm{H}-\mathrm{C}$ & $\mathrm{H}-\mathrm{U}$ & NO-FI & VL-M & VL-L & * & U & VH-W & VH-U & $\mathrm{L}-\mathrm{W}$ & VH-U & VL-C & $\mathrm{O} 1$ \\
\hline L-W & VL-FI & $\mathrm{H}-\mathrm{C}$ & VL-M & VL-C & H-FI & NO-FI & * & VL-C & & L-C & VL-W & $\mathrm{H}-\mathrm{C}$ & VL-U & L-W & $\mathrm{O} 2$ \\
\hline $\mathrm{H}-\mathrm{L}$ & & & & & $\begin{array}{c}\mathrm{L}-\mathrm{C} \\
*\end{array}$ & $*$ & & & $L-A$ & & & & & & 1 \\
\hline $\mathrm{H}-\mathrm{U}$ & V & VH-W & $\mathrm{L}$ & 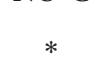 & $\mathrm{H}-\mathrm{F}$ & $V L-N$ & VL- & & $\mathrm{H}-\mathrm{C}$ & 1- & $\mathrm{H}-\mathrm{ML}$ & $V \mathrm{~L}-\mathrm{L}$ & $1-$ & $\mathrm{H}-\mathrm{M}$ & E2 \\
\hline & $\mathrm{H}-\mathrm{M}$ & & & & & (1) & o & & $\sqrt{V L}$ & & & & & & F3 \\
\hline & $\mathrm{VH}-$ & & 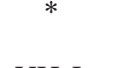 & & & & & & & & & & & & 3 \\
\hline $\mathrm{I}-\mathrm{M}$ & $\mathrm{ML}$ & * & VH-L & VH-U & H-FI & H-M & VH-L & $\mathrm{H}-\mathrm{W}$ & $\mathrm{H}-\mathrm{C}$ & L-C & $\mathrm{H}-\mathrm{U}$ & VH-C & {$[-\mathrm{L}$} & VH-L & L1 \\
\hline $\mathrm{VH}-\mathrm{U}$ & * & VH-W & VH-L & $\mathrm{VH}-\mathrm{U}$ & VH-FI & VH-W & VH-L & VH-U & VH-M & $\begin{array}{l}\mathrm{VH} \\
\mathrm{M}\end{array}$ & $\mathrm{VH}-\mathrm{U}$ & VH-C & VH-U & VH-L & $\mathrm{L} 2$ \\
\hline * & $\mathrm{H}-\mathrm{M}$ & $\mathrm{H}-\mathrm{C}$ & VL-N & $\mathrm{L}-\mathrm{U}$ & $\mathrm{I}$ & -1 & $\begin{array}{l}\text { VL-L } \\
\text { Expert }\end{array}$ & $\begin{array}{l}\text { VL-C } \\
6\end{array}$ & L-M & H-ML & $\mathrm{H}-\mathrm{U}$ & NO-L & $\mathrm{H}-\mathrm{U}$ & M & L3 \\
\hline VH-U & $\begin{array}{l}\text { VH- } \\
\text { ML }\end{array}$ & $\begin{array}{l}\text { VH- } \\
\text { ML }\end{array}$ & $-M$ & $\mathrm{H}-\mathrm{L}$ & $\mathrm{H}-\mathrm{U}$ & $\begin{array}{l}\text { VL- } \\
\text { ML }\end{array}$ & H-W & VH-C & -ML & $\mathrm{L}-\mathrm{U}$ & L-M & L-W & L-C & * & $\mathrm{T} 1$ \\
\hline $\mathrm{H}-\mathrm{L}$ & L-ML & VH-C & VH-W & $\begin{array}{l}\text { NO- } \\
\text { ML }\end{array}$ & $\mathrm{NO}-\mathrm{U}$ & L-M & VL & VL-C & VL-M & VH-FI & L-W & $\mathrm{L}-\mathrm{U}$ & * & L-ML & $\mathrm{T} 2$ \\
\hline NO-M & $\begin{array}{l}\text { NO- } \\
\text { ML }\end{array}$ & $\mathrm{N}$ & $\mathrm{H}-\mathrm{L}$ & L-C & V & V & $\begin{array}{l}\text { VL- } \\
\text { ML }\end{array}$ & VL-M & VL-C & U & $\mathrm{H}-\mathrm{C}$ & * & VL-M & H-FI & T3 \\
\hline VL-U & VL-W & $\mathrm{H}-\mathrm{M}$ & $\mathrm{H}-\mathrm{Fl}$ & $-U$ & L-C & $\mathrm{H}-\mathrm{K}$ & $\mathrm{L}-\mathrm{U}$ & VH-M & $\begin{array}{l}\text { VH- } \\
\text { ML }\end{array}$ & VH-C & * & L-FI & VH-M & $\mathrm{H}-\mathrm{L}$ & $\mathrm{T} 4$ \\
\hline VL-U & L-ML & $\mathrm{H}-\mathrm{M}$ & L-V & $-M$ & $\mathrm{H}-\mathrm{U}$ & $\begin{array}{l}\text { VH- } \\
\text { ML }\end{array}$ & $\mathrm{H}-\mathrm{W}$ & $\mathrm{H}-\mathrm{C}$ & VH-C & * & VH-M & VL-L & $\mathrm{H}-\mathrm{U}$ & NO-L & T5 \\
\hline NO-M & $\begin{array}{l}\text { NO- } \\
\text { ML }\end{array}$ & $\mathrm{NO}-\mathrm{U}$ & VL-W & $\mathrm{H}-\mathrm{L}$ & VL-U & VL-FI & $\begin{array}{l}\text { VL- } \\
\text { ML }\end{array}$ & $\mathrm{H}-\mathrm{C}$ & * & $\begin{array}{l}\text { VH- } \\
\text { ML }\end{array}$ & VH-M & VL-L & $\mathrm{H}-\mathrm{U}$ & VL-W & T6 \\
\hline $\mathrm{H}-\mathrm{L}$ & H-M & H-M & VL-W & $\mathrm{H}-\mathrm{L}$ & $\mathrm{NO}-\mathrm{U}$ & VL-W & $\begin{array}{l}\text { VL- } \\
\text { ML }\end{array}$ & * & VH-L & H-M & VH-M & L-M & VH-M & VL-W & $\mathrm{O} 1$ \\
\hline
\end{tabular}


TABle 15: Continued.

\begin{tabular}{|c|c|c|c|c|c|c|c|c|c|c|c|c|c|c|c|}
\hline L3 & L2 & L1 & E3 & E2 & E1 & O3 & $\mathrm{O} 2$ & $\mathrm{O} 1$ & T6 & T5 & $\mathrm{T} 4$ & T3 & $\mathrm{T} 2$ & $\mathrm{~T} 1$ & \\
\hline VH-U & $\begin{array}{l}\text { VH- } \\
\text { ML }\end{array}$ & $\mathrm{H}-\mathrm{M}$ & $\mathrm{H}-\mathrm{M}$ & VH-C & VL-U & $\begin{array}{l}\text { VL- } \\
\text { ML }\end{array}$ & * & VL-FI & $\mathrm{L}-\mathrm{C}$ & $\mathrm{L}-\mathrm{U}$ & $\mathrm{H}-\mathrm{C}$ & $\mathrm{H}-\mathrm{M}$ & $\mathrm{L}-\mathrm{C}$ & JO-L & $\mathrm{D} 2$ \\
\hline VL-U & $\begin{array}{l}\text { NO- } \\
\text { ML }\end{array}$ & $\mathrm{NO}-\mathrm{U}$ & VL-W & VL-C & $\mathrm{NO}-\mathrm{U}$ & $*$ & $\mathrm{~L}-\mathrm{U}$ & $\begin{array}{l}\text { VL- } \\
\text { ML }\end{array}$ & $\begin{array}{l}\text { VH- } \\
\text { ML }\end{array}$ & $\begin{array}{l}\text { VH- } \\
\text { ML }\end{array}$ & $\mathrm{H}-\mathrm{C}$ & $\mathrm{H}-\mathrm{M}$ & L-C & NO-L & $\mathrm{O}_{3}$ \\
\hline L-ML & H-M & $\mathrm{H}-\mathrm{M}$ & $\mathrm{NO}-\mathrm{C}$ & $\begin{array}{l}\text { NO- } \\
\text { ML }\end{array}$ & * & $\mathrm{NO}-\mathrm{U}$ & $\begin{array}{l}\text { VL- } \\
\text { ML }\end{array}$ & VL-W & VH-FI & $\begin{array}{l}\text { NO- } \\
\text { ML }\end{array}$ & VL-M & $\mathrm{H}-\mathrm{M}$ & VH-L & $\mathrm{H}-\mathrm{U}$ & E1 \\
\hline VH-U & $\begin{array}{l}\text { VH- } \\
\text { ML }\end{array}$ & VH-U & L-C & $*$ & $\mathrm{H}-\mathrm{U}$ & $\begin{array}{l}\text { VL- } \\
\text { ML }\end{array}$ & $\begin{array}{l}\text { VL- } \\
\text { ML }\end{array}$ & L-M & $\mathrm{NO}-\mathrm{C}$ & H-M & IL-M & VL-L & $\mathrm{H}-\mathrm{U}$ & $\mathrm{H}-\mathrm{ML}$ & $\mathrm{E} 2$ \\
\hline $\mathrm{H}-\mathrm{L}$ & H-M & $\mathrm{H}-\mathrm{M}$ & * & VH-C & $\begin{array}{l}\text { VH- } \\
\text { ML }\end{array}$ & L-M & $\begin{array}{l}\text { VL- } \\
\text { ML }\end{array}$ & L-M & H-ML & $\begin{array}{l}\text { VH- } \\
\text { ML }\end{array}$ & VH-M & L-W & $\mathrm{H}-\mathrm{W}$ & L-ML & E3 \\
\hline H-L & $\begin{array}{l}\text { VH- } \\
\text { ML }\end{array}$ & * & $\begin{array}{l}\text { VH- } \\
\text { ML }\end{array}$ & VH-C & $\mathrm{H}-\mathrm{U}$ & H-W & $\begin{array}{l}\text { VH- } \\
\text { ML }\end{array}$ & $\mathrm{H}-\mathrm{C}$ & L-ML & H-M & $\mathrm{H}-\mathrm{C}$ & $\mathrm{H}-\mathrm{M}$ & $\mathrm{L}-\mathrm{C}$ & VH-M & L1 \\
\hline H-L & $*$ & $\mathrm{NO}-\mathrm{U}$ & $\begin{array}{l}\text { VH- } \\
\text { ML }\end{array}$ & VH-C & $\mathrm{H}-\mathrm{U}$ & H-W & $\begin{array}{l}\mathrm{VH}- \\
\mathrm{ML}\end{array}$ & $\mathrm{H}-\mathrm{C}$ & H-ML & $\mathrm{L}-\mathrm{U}$ & VH-M & VH-U & $\mathrm{H}-\mathrm{FI}$ & VH-M & L2 \\
\hline * & L-ML & $\begin{array}{l}\text { VH- } \\
\text { ML }\end{array}$ & $\begin{array}{l}\text { VH- } \\
\text { ML }\end{array}$ & $\mathrm{H}-\mathrm{L}$ & VH-C & H-W & VL-U & L-FI & H-ML & $\mathrm{L}-\mathrm{U}$ & $\mathrm{H}-\mathrm{C}$ & L-FI & /L-M & L-FI & L3 \\
\hline \multicolumn{16}{|c|}{ Expert 7} \\
\hline $\begin{array}{l}\mathrm{VH}- \\
\mathrm{ML}\end{array}$ & VL-C & $\mathrm{H}-\mathrm{ML}$ & L-ML & L-C & L-M & NO-W & NO-FI & $\mathrm{NO}-\mathrm{C}$ & L-M & VL-FI & $\begin{array}{l}\text { VL- } \\
\text { ML }\end{array}$ & L-W & $\mathrm{NO}-\mathrm{U}$ & $*$ & $\mathrm{~T} 1$ \\
\hline VL-C & $\mathrm{H}-\mathrm{U}$ & VL-W & VL-L & L-C & L-FI & $\begin{array}{l}\text { VL- } \\
\text { ML }\end{array}$ & L-U & VL-M & $\mathrm{H}-\mathrm{U}$ & H-ML & L- & $\mathrm{L}-\mathrm{U}$ & $*$ & $\mathrm{~L}-\mathrm{U}$ & $\mathrm{T} 2$ \\
\hline L-M & VL-C & L-ML & VL-L & VL-L & $\begin{array}{l}\text { NO- } \\
\text { ML }\end{array}$ & VL-W & L-M & VL-FI & $\mathrm{H}-\mathrm{U}$ & L-ML & VL-M & * & $\mathrm{L}-\mathrm{U}$ & L-ML & T3 \\
\hline $\mathrm{H}-\mathrm{W}$ & IL-C & L-W & VL-L & H-W & H-ML & $\mathrm{H}-\mathrm{L}$ & $\mathrm{L}-\mathrm{C}$ & UI_U & $\mathrm{H}-\mathrm{W}$ & L-ML & * & $I-N$ & IH-C & J-U & $\mathrm{T} 4$ \\
\hline $\mathrm{H}-\mathrm{W}$ & $\mathrm{H}-\mathrm{M}$ & ML & $\mathrm{O}-\mathrm{C}$ & {$[-W$} & $\mathrm{L}-\mathrm{U}$ & L-M & & 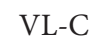 & $\mathrm{H}-1$ & * & L- & & & C & T5 \\
\hline $\mathrm{H}-\mathrm{W}$ & $\mathrm{H}-\mathrm{L}$ & $\mathrm{H}-\mathrm{U}$ & $\mathrm{ML}$ & $\mathrm{H}-\mathrm{U}$ & L-ML & VL-W & & VL- & * & & & & & $\mathrm{L}-$ & T6 \\
\hline H-W & H-FI & $\mathrm{H}-\mathrm{ML}$ & $\mathrm{NO}-\mathrm{U}$ & $\mathrm{H}-\mathrm{M}$ & $\mathrm{L}-\mathrm{U}$ & VL-M & VL-FI & $*$ & VL-M & & $\mathrm{H}-\mathrm{C}$ & $L-1$ & VL-W & VL-C & $\mathrm{O} 1$ \\
\hline NO-L & $\mathrm{H}-\mathrm{U}$ & $\mathrm{VH}-$ & $\begin{array}{l}\text { NO- } \\
\text { ML }\end{array}$ & H-W & $\begin{array}{l}\text { NO- } \\
\text { ML }\end{array}$ & NO-M & * & $\mathrm{NO}-\mathrm{C}$ & NO-L & $-M L$ & $M$ & & I & $\mathrm{O}-\mathrm{C}$ & $\mathrm{O} 2$ \\
\hline NO-L & VL-U & L-M & L-M & $\begin{array}{l}\text { VL- } \\
\text { ML }\end{array}$ & NO-C & * & L-U & NO-C & VL-M & L-ML & VH-W & L-ML & L-U & NO-M & $\mathrm{O} 3$ \\
\hline NO-L & L-W & L-M & $\begin{array}{l}\text { VL- } \\
\text { ML }\end{array}$ & NO-M & $*$ & H-L & L-FI & L-L & VL-M & VL-U & L-M & M & $\mathrm{L}$ & -ML & E1 \\
\hline NO-L & VL-U & L-M & $\begin{array}{l}\text { VL- } \\
\text { ML }\end{array}$ & $*$ & L-ML & NO-M & L-L & $\mathrm{MI}$ & $\mathrm{L}-\mathrm{U}$ & L-FI & NO-M & 1 & 1 & VL-C & E2 \\
\hline NO-L & VL-U & VL-W & $*$ & $\begin{array}{l}\text { VL- } \\
\text { ML }\end{array}$ & $\begin{array}{l}\text { NO- } \\
\text { ML }\end{array}$ & NO-M & VL-FI & $\mathrm{NO}-\mathrm{C}$ & NO-L & $\mathrm{O}-\mathrm{M}$ & L-M & W & $\mathrm{U}$ & L-ML & E3 \\
\hline NO-L & L-W & $*$ & $\mathrm{NO}-\mathrm{U}$ & $\begin{array}{l}\text { NO- } \\
\text { ML }\end{array}$ & NO-W & VL-M & VH-L & VL-W & VL-U & $\begin{array}{c}\mathrm{NO}- \\
\mathrm{ML}\end{array}$ & $\mathrm{OO}-\mathrm{C}$ & L-W & $\mathrm{NO}-\mathrm{U}$ & $\mathrm{H}-\mathrm{ML}$ & L1 \\
\hline NO-L & $*$ & NO-L & $\mathrm{NO}-\mathrm{U}$ & $\begin{array}{l}\text { NO- } \\
\text { ML }\end{array}$ & VL-M & NO-M & VH-L & VH-C & VL-M & VL-U & VH-W & $\mathrm{OO}-\mathrm{C}$ & $\mathrm{H}-\mathrm{C}$ & L-ML & $\mathrm{L} 2$ \\
\hline * & $\mathrm{O}-\mathrm{W}$ & NO-L & $\mathrm{NO}-\mathrm{U}$ & $\begin{array}{l}\text { NO- } \\
\text { ML }\end{array}$ & NO-L & NO-M & L-ML & L-ML & NO-FI & NO-W & L-FI & $\mathrm{JO}-\mathrm{C}$ & $\mathrm{H}-\mathrm{C}$ & VL-C & L3 \\
\hline \multicolumn{16}{|c|}{ Expert 8} \\
\hline NO-FI & NO-W & $\begin{array}{l}\text { VL- } \\
\text { ML }\end{array}$ & $\mathrm{L}-\mathrm{L}$ & VL-L & NO-FI & NO-M & M & NO-C & NO-FI & NO-FI & VL-W & VL-L & L-L & * & $\mathrm{T} 1$ \\
\hline NO-M & NO-W & NO-M & $\mathrm{NO}-\mathrm{U}$ & VL-L & $\mathrm{L}-\mathrm{C}$ & L-FI & $\begin{array}{l}\text { VI } \\
\text { M }\end{array}$ & L-U & VL-M & $\mathrm{H}-\mathrm{U}$ & H-ML & L-C & $*$ & VH-L & $\mathrm{T} 2$ \\
\hline L-FI & NO-U & $\begin{array}{c}\mathrm{NO}- \\
\mathrm{ML}\end{array}$ & L-L & $\mathrm{NO}-\mathrm{U}$ & NO-C & VL-M & VL-FI & VL-C & VL-U & $\mathrm{L}-\mathrm{L}$ & $-\mathrm{MIL}$ & $*$ & $\Pi-\mathrm{V}$ & L-W & T3 \\
\hline $\mathrm{H}-\mathrm{U}$ & NO-W & $\begin{array}{l}\text { VL- } \\
\text { ML }\end{array}$ & $\mathrm{NO}-\mathrm{U}$ & L-L & VL-C & VL-W & $\begin{array}{l}\text { VL- } \\
\text { ML }\end{array}$ & $\mathrm{L}-\mathrm{U}$ & $\begin{array}{l}\text { VH- } \\
\text { ML }\end{array}$ & L-W & * & $\mathrm{L}$ & VL-L & $\mathrm{H}-\mathrm{M}$ & $\mathrm{T} 4$ \\
\hline $\mathrm{H}-\mathrm{U}$ & VL-L & NO-FI & L-L & $\mathrm{NO}-\mathrm{U}$ & VL-C & VL-U & L-C & VL-FI & $\begin{array}{l}\text { VH- } \\
\text { ML }\end{array}$ & $*$ & $\mathrm{~L}-\mathrm{U}$ & VL-M & $\mathrm{H}-\mathrm{L}$ & NO-W & T5 \\
\hline L-FI & NO-M & $\mathrm{I}-\mathrm{L}$ & L-L & L-L & $\mathrm{O}-\mathrm{C}$ & VL-W & $\mathrm{I}$ & $\begin{array}{l}\text { VL- } \\
\text { ML }\end{array}$ & * & L-C & $\mathrm{I}-\mathrm{C}$ & M & $\mathrm{H}-\mathrm{L}$ & L-W & T6 \\
\hline NO-M & VL-FI & $\mathrm{NO}-\mathrm{C}$ & NO-L & L-L & VL-C & VL-1 & VL-U & * & $\begin{array}{l}\text { VH- } \\
\text { ML }\end{array}$ & VL-C & $\mathrm{H}-\mathrm{C}$ & L-ML & VL-W & $\mathrm{H}-\mathrm{L}$ & $\mathrm{O} 1$ \\
\hline $\begin{array}{l}\text { VL-M } \\
\text { NO-M }\end{array}$ & H-L & $\begin{array}{l}\mathrm{L}-\mathrm{W} \\
\mathrm{H}-\mathrm{C}\end{array}$ & L-M & $\mathrm{O}-\mathrm{U}$ & $\mathrm{O}-\mathrm{FI}$ & VL-M & $*$ & VL- & VL-C & H-U & & & & & $\mathrm{O} 2$ \\
\hline$N U-11$ & $1-\mathrm{L}$ & $x_{2}$ & - & 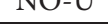 & 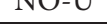 & 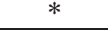 & & 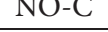 & $I_{-1}$ & 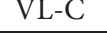 & & -1 & L-U & H-ML & $\mathrm{O}_{3}^{3}$ \\
\hline
\end{tabular}


TABle 15: Continued.

\begin{tabular}{|c|c|c|c|c|c|c|c|c|c|c|c|c|c|c|c|}
\hline L3 & L2 & L1 & E3 & E2 & E1 & $\mathrm{O} 3$ & $\mathrm{O} 2$ & O1 & T6 & T5 & T4 & T3 & $\mathrm{T} 2$ & $\mathrm{~T} 1$ & \\
\hline NO-L & $\mathrm{NO}-\mathrm{U}$ & VL-L & L-W & $\mathrm{NO}-\mathrm{U}$ & * & VL-M & VL-U & VL-C & $\mathrm{H}-\mathrm{W}$ & VL-C & VL-M & VL-M & H-L & L-ML & E1 \\
\hline NO-L & L-FI & NO-M & $\begin{array}{l}\text { VL- } \\
\text { ML }\end{array}$ & * & VL-C & L-M & NO-U & $\mathrm{NO}-\mathrm{C}$ & $\begin{array}{l}\text { NO- } \\
\text { ML }\end{array}$ & VH-M & L-ML & NO-C & $\mathrm{H}-\mathrm{W}$ & H-M & $\mathrm{E} 2$ \\
\hline $\mathrm{VH}-\mathrm{C}$ & $\mathrm{H}-\mathrm{U}$ & VL-L & * & L-L & VL-C & VH-C & L-M & VL-FI & H-ML & $\mathrm{H}-\mathrm{L}$ & $\mathrm{H}-\mathrm{U}$ & L-ML & $\mathrm{H}-\mathrm{U}$ & H-M & E3 \\
\hline H-M & NO-L & * & $\mathrm{H}-\mathrm{L}$ & $\mathrm{NO}-\mathrm{U}$ & NO-C & L-M & $\begin{array}{l}\text { VL- } \\
\text { ML }\end{array}$ & NO-C & L-U & H-FI & H-ML & $\mathrm{NO}-\mathrm{U}$ & H-M & VH-L & L1 \\
\hline NO-L & * & $\mathrm{NO}-\mathrm{U}$ & $\begin{array}{l}\text { NO- } \\
\text { ML }\end{array}$ & $\mathrm{NO}-\mathrm{U}$ & H-ML & VL-W & $\mathrm{NO}-\mathrm{U}$ & $\mathrm{NO}-\mathrm{C}$ & L-ML & $\mathrm{H}-\mathrm{U}$ & VH-W & $\begin{array}{l}\text { NO- } \\
\text { ML }\end{array}$ & $\mathrm{H}-\mathrm{W}$ & VH-L & L2 \\
\hline * & NO-W & $\begin{array}{l}\text { NO- } \\
\text { ML }\end{array}$ & $\mathrm{NO}-\mathrm{C}$ & $\mathrm{NO}-\mathrm{U}$ & VL-C & VL-W & $\mathrm{H}-\mathrm{C}$ & NO-M & L-U & L-ML & $\mathrm{H}-\mathrm{U}$ & $\begin{array}{l}\text { NO- } \\
\text { ML }\end{array}$ & $\mathrm{H}-\mathrm{ML}$ & H-M & L3 \\
\hline \multicolumn{16}{|c|}{ Expert 9} \\
\hline $\begin{array}{l}\mathrm{NH}- \\
\mathrm{ML}\end{array}$ & VH-FI & $\mathrm{H}-\mathrm{C}$ & $\begin{array}{l}\text { VL- } \\
\text { ML }\end{array}$ & $\mathrm{H}-\mathrm{W}$ & VH-C & L-ML & L-U & L-M & L-M & $\begin{array}{l}\text { VH- } \\
\text { ML }\end{array}$ & VH-L & $\mathrm{NO}-\mathrm{U}$ & L-C & * & $\mathrm{T} 1$ \\
\hline $\mathrm{HH}-\mathrm{U}$ & VL-U & $\mathrm{H}-\mathrm{C}$ & L-M & $\begin{array}{l}\text { VL- } \\
\text { ML }\end{array}$ & VL-C & VL-M & VH-FI & L-W & VL-C & H-W & H-M & H-L & * & VL-U & $\mathrm{T} 2$ \\
\hline NO-M & L-ML & VL-M & VL-FI & $\begin{array}{l}\text { VL- } \\
\text { ML }\end{array}$ & VL-M & VL-C & L-U & $\mathrm{H}-\mathrm{C}$ & $\mathrm{H}-\mathrm{C}$ & $\mathrm{L}-\mathrm{U}$ & $\begin{array}{l}\text { VL- } \\
\text { ML }\end{array}$ & * & VH-W & $\begin{array}{l}\text { VL- } \\
\text { ML }\end{array}$ & T3 \\
\hline $\mathrm{H}-\mathrm{L}$ & L-ML & VH-W & L-ML & $\mathrm{L}-\mathrm{U}$ & VH-M & VH-U & $\mathrm{H}-\mathrm{L}$ & H-ML & VH-U & VH-L & * & L-W & VH-C & $\mathrm{H}-\mathrm{U}$ & $\mathrm{T} 4$ \\
\hline L-M & VL-U & VL-M & VL-M & $\mathrm{H}-\mathrm{L}$ & VH-M & $\mathrm{H}-\mathrm{C}$ & $\mathrm{H}-\mathrm{L}$ & H-ML & $\mathrm{H}-\mathrm{C}$ & * & VH-L & L-W & $\mathrm{H}-\mathrm{L}$ & $\begin{array}{l}\text { VL- } \\
\text { ML }\end{array}$ & T5 \\
\hline JL-M & VL-U & VL-M & $\mathrm{NO}-\mathrm{C}$ & L-U & H-FI & VL-W & VH-C & $\begin{array}{l}\text { VL- } \\
\text { ML }\end{array}$ & * & VH-C & H-M & $\mathrm{H}-\mathrm{L}$ & VH-U & L-M & T6 \\
\hline $\mathrm{H}-\mathrm{L}$ & NO-W & VH-W & NO-C & $\mathrm{L}-\mathrm{U}$ & $\mathrm{H}-\mathrm{U}$ & VL-W & $\begin{array}{l}\text { VL- } \\
\text { ML }\end{array}$ & $*$ & $\mathrm{VH}-\mathrm{U}$ & VH-W & H-M & $\begin{array}{l}\text { VL- } \\
\text { ML }\end{array}$ & H-L & L-M & $\mathrm{O} 1$ \\
\hline L-M & VL-U & $\mathrm{H}-\mathrm{C}$ & L-M & $\mathrm{L}-\mathrm{U}$ & VL-U & NO-M & * & NO-L & NO-C & VL-W & H-FI & VI & L-C & NO-FI & $\mathrm{O} 2$ \\
\hline $\mathrm{O}-\mathrm{M}$ & VL-U & VH-W & $\mathrm{NO}-\mathrm{C}$ & $\mathrm{H}-\mathrm{C}$ & $\mathrm{O}-\mathrm{C}$ & * & L-M & VH-FI & $\mathrm{VH}-\mathrm{U}$ & L- & H-ML & $\mathrm{VH}$ & $\mathrm{L}-\mathrm{C}$ & NO-FI & $\mathrm{O} 3$ \\
\hline /H-C & VH-FI & $\mathrm{H}-\mathrm{C}$ & H-ML & H-ML & * & H-M & H-L & H-FI & $\mathrm{H}-\mathrm{C}$ & H-ML & $\mathrm{L}-\mathrm{M}$ & VH-M & $\mathrm{H}-\mathrm{L}$ & L-M & E1 \\
\hline $\mathrm{H}-\mathrm{L}$ & H-FI & $\mathrm{H}-\mathrm{C}$ & L-W & * & H-ML & NO-M & L-M & L-C & L-W & VL-W & $\begin{array}{l}\text { VH- } \\
\text { ML }\end{array}$ & H-FI & VH-W & H-FI & E2 \\
\hline $\mathrm{H}-\mathrm{U}$ & H-FI & L-W & * & $\begin{array}{l}\text { VH- } \\
\text { ML }\end{array}$ & VH-M & H-ML & $\begin{array}{l}\text { VL- } \\
\text { ML }\end{array}$ & VL-U & VL-W & VH-M & $\mathrm{H}-\mathrm{C}$ & $\mathrm{H}-\mathrm{U}$ & H-L & H-M & E3 \\
\hline VH-FI & VH-FI & * & VH-M & VH-L & VH-M & $\mathrm{VH}-\mathrm{U}$ & VH-C & VL-U & VL-W & VL-W & $\begin{array}{l}\text { VH- } \\
\text { ML }\end{array}$ & VL-U & VH-W & $\begin{array}{l}\text { VH- } \\
\text { ML }\end{array}$ & L1 \\
\hline $\mathrm{VH}-\mathrm{C}$ & * & VH-U & VH-M & $\begin{array}{l}\text { VH- } \\
\text { ML }\end{array}$ & VH-M & $\mathrm{VH}-\mathrm{U}$ & VH-C & VH-FI & $\mathrm{VH}-\mathrm{U}$ & VH-L & VH-L & VH-C & $\begin{array}{l}\text { VH- } \\
\text { ML }\end{array}$ & $\begin{array}{l}\text { VH- } \\
\text { ML }\end{array}$ & L2 \\
\hline$*$ & H-FI & $\mathrm{H}-\mathrm{C}$ & H-ML & $\mathrm{H}-\mathrm{U}$ & VH-M & H-L & $\begin{array}{l}\text { L-M } \\
\text { Expert }\end{array}$ & $10^{\mathrm{L}-\mathrm{C}}$ & VH-U & $\mathrm{H}-\mathrm{W}$ & VH-L & $\mathrm{NO}-\mathrm{U}$ & VH-C & $\mathrm{H}-\mathrm{U}$ & L3 \\
\hline VL-U & L-C & $\mathrm{H}-\mathrm{U}$ & $\mathrm{H}-\mathrm{C}$ & $\begin{array}{l}\text { VL- } \\
\text { ML }\end{array}$ & $\begin{array}{l}\mathrm{NO} \\
\mathrm{ML}\end{array}$ & H-FI & VL-M & $\mathrm{H}-\mathrm{C}$ & VL-W & $\mathrm{H}-\mathrm{C}$ & VH-L & L-U & H-FI & * & $\mathrm{T} 1$ \\
\hline $\begin{array}{l}\text { VL- } \\
\text { ML }\end{array}$ & L-C & $\mathrm{H}-\mathrm{C}$ & H-ML & L-M & VH-M & $\mathrm{H}-\mathrm{C}$ & VL-FI & L-M & VL-W & H-FI & $\mathrm{H}-\mathrm{C}$ & VL-W & * & L-ML & $\mathrm{T} 2$ \\
\hline JO-M & $\begin{array}{l}\text { VL- } \\
\text { ML }\end{array}$ & L-W & VL-W & $\begin{array}{l}\text { VH- } \\
\text { ML }\end{array}$ & $\mathrm{H}$ & VL-W & W & VL-U & L-ML & $-U$ & L-C & * & $\begin{array}{l}\text { VL- } \\
\text { ML }\end{array}$ & $\mathrm{H}-\mathrm{U}$ & T3 \\
\hline L-U & $\mathrm{H}-\mathrm{W}$ & VL-W & VH-M & H-C & $\mathrm{H}-\mathrm{U}$ & VL-W & $\mathrm{U}$ & NO-FI & $\begin{array}{l}\text { VL- } \\
\text { ML }\end{array}$ & $-\mathrm{L}$ & * & L-C & $\begin{array}{l}\text { VL- } \\
\text { ML }\end{array}$ & $\mathrm{H}-\mathrm{W}$ & $\mathrm{T} 4$ \\
\hline VL-U & $\begin{array}{l}\text { VL- } \\
\text { ML }\end{array}$ & $\mathrm{H}-\mathrm{C}$ & L-V & H-ML & VH-M & NO-C & $\mathrm{U}$ & NO-FI & VH-U & * & $\begin{array}{l}\text { VL- } \\
\text { ML }\end{array}$ & L-W & $\begin{array}{l}\text { VL- } \\
\text { ML }\end{array}$ & H-L & T5 \\
\hline NO-M & VL-FI & L-U & $\mathrm{H}-\mathrm{C}$ & $\begin{array}{l}\text { VL- } \\
\text { ML }\end{array}$ & $\begin{array}{l}\text { NO- } \\
\text { ML }\end{array}$ & NO-C & $\mathrm{NO}-\mathrm{U}$ & VL-U & * & VL-M & $\mathrm{H}-\mathrm{C}$ & $\mathrm{H}-\mathrm{L}$ & $\mathrm{L}-\mathrm{W}$ & H-ML & T6 \\
\hline $\mathrm{H}-\mathrm{L}$ & $\begin{array}{l}\text { VL- } \\
\text { ML }\end{array}$ & L-U & $-M$ & $\mathrm{~L}-\mathrm{U}$ & VL-M & NO-C & $\mathrm{U}$ & * & $-\mathrm{C}$ & L-U & $\mathrm{H}-\mathrm{C}$ & L-W & L-W & I-ML & O1 \\
\hline VH-U & VL-L & $\mathrm{H}-\mathrm{U}$ & VL-C & $\begin{array}{l}\text { VL- } \\
\text { ML }\end{array}$ & $\mathrm{H}$ & NO-C & * & VL-U & $\mathrm{U}$ & L-U & & $\mathrm{H}-\mathrm{L}$ & $\begin{array}{l}\text { VL- } \\
\text { ML }\end{array}$ & -ML & $\mathrm{O} 2$ \\
\hline VL-U & L-C & VL-W & $\mathrm{H}-\mathrm{W}$ & $\mathrm{L}-\mathrm{U}$ & L-C & * & VL-M & $\mathrm{H}-\mathrm{C}$ & L-ML & $\mathrm{H}-\mathrm{M}$ & VH-L & VL-W & H-FI & VL-M & O3 \\
\hline -ML & VL-C & L & NO-M & $\mathrm{N}$ & * & $\mathrm{H}-\mathrm{Fl}$ & L-W & $\mathrm{H}-\mathrm{C}$ & $\mathrm{U}$ & $-M$ & & N & $\begin{array}{l}\text { VL- } \\
\text { ML }\end{array}$ & ML & E1 \\
\hline $\mathrm{H}-\mathrm{C}$ & $\mathrm{L}$ & VL-W & L-V & * & H-M & $\begin{array}{l}\text { VL- } \\
\text { ML }\end{array}$ & N & VL-U & L-ML & $\mathrm{H}$ & VL- & L-W & $\mathrm{L}-\mathrm{W}$ & -ML & E2 \\
\hline$[-L$ & $\begin{array}{c}\mathrm{H}-\mathrm{W} \\
\mathrm{L}-\mathrm{C}\end{array}$ & $\begin{array}{c}\text { VL-W } \\
*\end{array}$ & $\stackrel{*}{*}$ & H-ML & VL-M & VL-C & NO-W & NO-FI & $\mathrm{VH}$ & $\mathrm{H}$ & $\mathrm{H}-\mathrm{C}$ & $\mathrm{VL}$ & $\mathrm{H}$ & L-ML & E3 \\
\hline & & & & & & & & & & & $\mathrm{H}$ & & $\mathrm{H}-\mathrm{F}$ & -ML & L1 \\
\hline
\end{tabular}


TABLE 15: Continued.

\begin{tabular}{|c|c|c|c|c|c|c|c|c|c|c|c|c|c|c|c|}
\hline L3 & L2 & L1 & E3 & E2 & E1 & $\mathrm{O} 3$ & $\mathrm{O} 2$ & $\mathrm{O} 1$ & T6 & T5 & T4 & T3 & T2 & T1 & \\
\hline $\mathrm{H}-\mathrm{L}$ & * & VL-W & VL-C & $\mathrm{L}-\mathrm{U}$ & L-C & $\begin{array}{l}\text { NO- } \\
\text { ML }\end{array}$ & NO-W & $\mathrm{H}-\mathrm{C}$ & $\mathrm{H}-\mathrm{C}$ & L-M & L-C & H-L & H-FI & $\begin{array}{l}\text { VH- } \\
\text { ML }\end{array}$ & L2 \\
\hline * & VL-FI & $\mathrm{L}-\mathrm{U}$ & H-W & $\mathrm{L}-\mathrm{U}$ & $\begin{array}{l}\text { VL- } \\
\text { ML }\end{array}$ & NO-FI & NO-L & L-M & $\mathrm{H}-\mathrm{C}$ & $\mathrm{L}-\mathrm{U}$ & $\mathrm{H}-\mathrm{C}$ & L-ML & H-FI & $\mathrm{H}-\mathrm{L}$ & L3 \\
\hline \multicolumn{16}{|c|}{ Expert 11} \\
\hline VH-U & VH-W & VH-W & VH-FI & VH-C & $\mathrm{L}-\mathrm{U}$ & NO-FI & VL-M & VL-M & L-W & L-C & VH-L & $\begin{array}{l}\text { VL- } \\
\text { ML }\end{array}$ & $\mathrm{H}-\mathrm{L}$ & * & $\mathrm{T} 1$ \\
\hline L-W & H-ML & L-L & H-ML & $\mathrm{NO}-\mathrm{U}$ & NO-W & VL-FI & $\mathrm{L}-\mathrm{U}$ & L-M & $\begin{array}{l}\text { VL- } \\
\text { ML }\end{array}$ & $\mathrm{H}-\mathrm{C}$ & $\mathrm{H}-\mathrm{W}$ & $\mathrm{H}-\mathrm{FI}$ & * & H-ML & $\mathrm{T} 2$ \\
\hline L-W & H-ML & $\begin{array}{l}\text { NO- } \\
\text { ML }\end{array}$ & H-ML & $\mathrm{L}-\mathrm{W}$ & VL-U & VL-L & VL-L & $\begin{array}{l}\text { VL- } \\
\text { ML }\end{array}$ & VL-U & H-ML & $\mathrm{H}-\mathrm{W}$ & * & $\mathrm{VH}-\mathrm{C}$ & VL-U & T3 \\
\hline $\begin{array}{l}\text { VL- } \\
\text { ML }\end{array}$ & L-ML & VH-C & $\mathrm{H}-\mathrm{U}$ & H-L & L-W & $\mathrm{H}-\mathrm{M}$ & L-FI & VH-L & VH-M & $\mathrm{NO}-\mathrm{U}$ & * & $\mathrm{L}-\mathrm{U}$ & $\begin{array}{l}\text { VH- } \\
\text { ML }\end{array}$ & $\mathrm{H}-\mathrm{W}$ & $\mathrm{T} 4$ \\
\hline H-FI & VL-M & $\mathrm{H}-\mathrm{U}$ & VH-FI & L-W & $\mathrm{H}-\mathrm{M}$ & VH-FI & $\mathrm{H}-\mathrm{L}$ & $\mathrm{H}-\mathrm{M}$ & VH-M & $*$ & VH-L & $\begin{array}{l}\text { VL- } \\
\text { ML }\end{array}$ & $\mathrm{H}-\mathrm{L}$ & NO-W & T5 \\
\hline $\begin{array}{l}\text { VL- } \\
\text { ML }\end{array}$ & L-ML & L-L & $\mathrm{H}-\mathrm{C}$ & H-FI & $\begin{array}{l}\text { VL- } \\
\text { ML }\end{array}$ & VL-C & VL-FI & H-M & * & VH-W & VH-L & $\begin{array}{l}\text { VL- } \\
\text { ML }\end{array}$ & H-L & VL-U & T6 \\
\hline $\mathrm{L}-\mathrm{W}$ & H-ML & L-L & H-ML & H-ML & NO-W & VL-U & VL-W & * & VH-M & VH-W & VH-L & $\mathrm{L}-\mathrm{U}$ & $\begin{array}{l}\text { VH- } \\
\text { ML }\end{array}$ & VL-U & $\mathrm{O} 1$ \\
\hline H-FI & L-ML & VL-FI & L-M & $\mathrm{H}-\mathrm{L}$ & VL-C & VL-U & * & VL-M & VL-FI & $\mathrm{L}-\mathrm{U}$ & $\begin{array}{l}\text { VL- } \\
\text { ML }\end{array}$ & $\mathrm{H}-\mathrm{L}$ & L-W & NO-W & $\mathrm{O} 2$ \\
\hline H-FI & L-ML & $\begin{array}{l}\text { NO- } \\
\text { ML }\end{array}$ & VL-L & VL-W & NO-W & * & NO-W & VL-U & VL-C & H-M & VH-L & VL-W & L-W & $\mathrm{NO}-\mathrm{W}$ & $\mathrm{O} 3$ \\
\hline $\mathrm{L}-\mathrm{U}$ & $\mathrm{H}-\mathrm{C}$ & $\mathrm{H}-\mathrm{U}$ & NO-FI & $\mathrm{NO}-\mathrm{U}$ & * & NO-FI & VL-M & $\begin{array}{l}\text { VL- } \\
\text { ML }\end{array}$ & $\begin{array}{l}\text { NO- } \\
\text { ML }\end{array}$ & VL-M & $\begin{array}{l}\text { VL- } \\
\text { ML }\end{array}$ & VL-W & H-L & H-ML & E1 \\
\hline $\mathrm{VH}-\mathrm{U}$ & VH-U & $\begin{array}{l}\text { VH- } \\
\text { ML }\end{array}$ & L-M & * & $\mathrm{H}-\mathrm{M}$ & VL-C & $\begin{array}{l}\text { VL- } \\
\text { ML }\end{array}$ & L-M & H-FI & $\mathrm{H}-\mathrm{C}$ & $\begin{array}{l}\text { VL- } \\
\text { ML }\end{array}$ & VL-W & H-L & H-L & E2 \\
\hline H-ML & $\mathrm{H}-\mathrm{C}$ & $\mathrm{H}-\mathrm{U}$ & * & VH-C & VH-M & L-U & VL-U & L-M & VH-M & $\mathrm{H}-\mathrm{M}$ & $\mathrm{H}-\mathrm{C}$ & VL-W & $\begin{array}{l}\text { VH- } \\
\text { ML }\end{array}$ & L-L & E3 \\
\hline H-ML & VH-L & $*$ & VH-FI & VH-C & H-M & H-M & VH-L & H-M & H-FI & $\mathrm{L}-\mathrm{U}$ & H-C & $\mathrm{H}-\mathrm{L}$ & H-L & VH-M & L1 \\
\hline H-ML & * & $\begin{array}{l}\text { NO- } \\
\text { ML }\end{array}$ & VH-FI & VH-C & $\mathrm{H}-\mathrm{M}$ & H-M & VH-L & $\mathrm{H}-\mathrm{M}$ & H-FI & VL-M & L-C & H-L & H-L & VH-M & L2 \\
\hline * & $\mathrm{L}-\mathrm{U}$ & $\mathrm{H}-\mathrm{U}$ & H-ML & VH-C & $\mathrm{H}-\mathrm{M}$ & $\mathrm{L}-\mathrm{U}$ & L-ML & $\mathrm{H}-\mathrm{M}$ & $\mathrm{H}-\mathrm{FI}$ & $\mathrm{L}-\mathrm{C}$ & VH-L & $\begin{array}{l}\text { VL- } \\
\text { ML }\end{array}$ & L-W & L-L & L3 \\
\hline \multicolumn{16}{|c|}{ Expert 12} \\
\hline M & 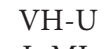 & $\mathrm{H}-\mathrm{M}$ & 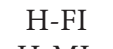 & H-C & & $\mathrm{O}$ & VH-L & L- & & & I- & L & $-M$ & & $\mathrm{~T} 1$ \\
\hline $\mathrm{H}-\mathrm{U}$ & L-ML & $L-W$ & H-ML & VL-C & NO-FI & VL-L & $\mathrm{H}-\mathrm{C}$ & $\mathrm{H}-\mathrm{W}$ & $V L-U$ & $\Pi-M$ & $\mathrm{~L}-\mathrm{C}$ & L-W & * & VH-L & $\mathrm{T} 2$ \\
\hline $\begin{array}{l}\text { NO- } \\
\text { ML }\end{array}$ & NO-L & $\mathrm{NO}-\mathrm{U}$ & $\mathrm{H}-\mathrm{W}$ & $\mathrm{L}-\mathrm{U}$ & VL-FI & VL-U & VL-L & VL-C & VL-FI & $\mathrm{H}-\mathrm{U}$ & H-ML & * & $\mathrm{VH}-\mathrm{U}$ & $\mathrm{L}-\mathrm{W}$ & $\mathrm{T} 3$ \\
\hline H-M & VH-M & VH-C & $\mathrm{H}-\mathrm{U}$ & $\mathrm{H}-\mathrm{L}$ & $\mathrm{L}-\mathrm{C}$ & $\mathrm{H}-\mathrm{M}$ & L-L & $\begin{array}{l}\text { VH- } \\
\text { ML }\end{array}$ & VH-U & VH-W & * & $\mathrm{H}-\mathrm{C}$ & VH-U & H-M & $\mathrm{T} 4$ \\
\hline$-M$ & $\mathrm{H}-\mathrm{M}$ & $\mathrm{H}-\mathrm{C}$ & VH-L & L-U & H-FI & VH-W & $\mathrm{H}-\mathrm{C}$ & $\mathrm{H}-\mathrm{W}$ & VH-U & * & L-FI & VH-M & $\mathrm{H}-\mathrm{L}$ & NO-W & T5 \\
\hline ML & VL-FI & VL-M & NO-L & NO-C & L-C & NO-FI & VL-L & VL-C & * & VL-L & VL-L & $\mathrm{H}-\mathrm{U}$ & NO-L & $\mathrm{L}-\mathrm{W}$ & T6 \\
\hline H-M & L-ML & L-W & $\mathrm{H}-\mathrm{C}$ & $\mathrm{H}-\mathrm{U}$ & NO-FI & VL-M & VL-L & $*$ & $\mathrm{VH}-\mathrm{U}$ & VH-W & VL-L & $\mathrm{H}-\mathrm{U}$ & VL-W & $\mathrm{H}-\mathrm{L}$ & $\mathrm{O} 1$ \\
\hline VL-W & VL-FI & $\mathrm{H}-\mathrm{C}$ & VL-M & VL-C & H-FI & NO-FI & $*$ & VL-C & & L-C & L-M & VH-M & VL-W & $\mathrm{H}-\mathrm{ML}$ & $\mathrm{O} 2$ \\
\hline $\mathrm{H}-\mathrm{U}$ & $\begin{array}{c}\text { L-ML } \\
\text { H-M }\end{array}$ & $\begin{array}{c}\text { VL-M } \\
\text { H-C }\end{array}$ & $\mathrm{H}$ & $\mathrm{I}$ & L-C & $N$ & L-I & $\mathrm{H}-$ & & $\mathrm{H}-\mathrm{C}$ & H-M & L-C & $\mathrm{L}$ & $\mathrm{H}-\mathrm{ML}$ & $\mathrm{O} 3$ \\
\hline & VH- & & $\mathrm{N}$ & $\mathrm{N}$ & & $\mathrm{N}$ & VL-L & VL & 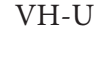 & & 1) & $-\mathrm{C}$ & $\mathrm{L}$ & IL & E1 \\
\hline $\mathrm{JH}-1$ & ML & $\mathrm{VH}$ & L-C & $*$ & FI & VL-M & $\mathrm{V}$ & L-M & H-C & $\mathrm{H}-\mathrm{U}$ & $\mathrm{H}-\mathrm{M}$ & $\mathrm{L}$ & $\mathrm{H}-\mathrm{U}$ & H-M & E2 \\
\hline $\mathrm{H}-\mathrm{M}$ & H-M & $\mathrm{H}-\mathrm{C}$ & $*$ & VH-U & VH-W & L-M & VL-L & L-M & $\begin{array}{l}\text { VL- } \\
\text { ML }\end{array}$ & $\mathrm{H}-\mathrm{C}$ & VL-L & $\mathrm{H}-\mathrm{U}$ & H-ML & H-M & E3 \\
\hline H-M & $\begin{array}{l}\text { VH- } \\
\text { ML }\end{array}$ & * & VH-L & VH-U & H-FI & H-M & VH-L & H-W & $\mathrm{H}-\mathrm{C}$ & $\mathrm{L}-\mathrm{C}$ & L-W & $\mathrm{H}-\mathrm{W}$ & L-ML & VH-L & L1 \\
\hline VH-U & * & $\mathrm{Vl}$ & $-\mathrm{L}$ & VH-U & VH-FI & VH-W & VH-L & $\mathrm{VH}-\mathrm{U}$ & VH-M & $\begin{array}{l}\text { VH- } \\
\text { ML }\end{array}$ & VH-U & VH-C & VH-U & VH-L & L2 \\
\hline * & VH-U & VH-W & VH-W & VH-FI & VH-C & $\mathrm{L}-\mathrm{U}$ & NO-FI & VL-M & VL-M & L-W & $\mathrm{L}-\mathrm{C}$ & VH-L & $\begin{array}{l}\text { VL- } \\
\text { ML }\end{array}$ & $\mathrm{H}-\mathrm{M}$ & L3 \\
\hline \multicolumn{16}{|c|}{ Expert 13} \\
\hline
\end{tabular}


TABle 15: Continued.

\begin{tabular}{|c|c|c|c|c|c|c|c|c|c|c|c|c|c|c|c|}
\hline $\mathrm{L} 3$ & $\mathrm{~L} 2$ & L1 & E3 & E2 & E1 & O3 & $\mathrm{O} 2$ & $\mathrm{O} 1$ & T6 & T5 & $\mathrm{T} 4$ & T3 & $\mathrm{T} 2$ & $\mathrm{~T} 1$ & \\
\hline VH-U & $\begin{array}{l}\text { VH- } \\
\text { ML }\end{array}$ & $\begin{array}{l}\text { VH- } \\
\text { ML }\end{array}$ & VH-M & $\mathrm{H}-\mathrm{L}$ & $\mathrm{H}-\mathrm{U}$ & $\begin{array}{l}\text { VL- } \\
\text { ML }\end{array}$ & $\mathrm{H}-\mathrm{W}$ & $\mathrm{H}-\mathrm{C}$ & $-M L$ & L-U & L-M & L-W & $\mathrm{L}-\mathrm{C}$ & * & $\mathrm{T} 1$ \\
\hline $\mathrm{H}-\mathrm{L}$ & L-ML & $\mathrm{L}-\mathrm{W}$ & H-ML & VL-C & NO-FI & L-M & $\begin{array}{l}\text { VL- } \\
\text { ML }\end{array}$ & VL-C & VL-M & VH-FI & $\mathrm{L}-\mathrm{W}$ & $\mathrm{L}-\mathrm{U}$ & * & $-M L$ & $\mathrm{~T} 2$ \\
\hline NO-M & NO-L & $\mathrm{NO}-\mathrm{U}$ & $\mathrm{H}-\mathrm{W}$ & $\mathrm{L}-\mathrm{U}$ & VL-FI & VL-FI & $\begin{array}{l}\text { VL- } \\
\text { ML }\end{array}$ & VL-M & VL-C & $\mathrm{L}-\mathrm{U}$ & $\mathrm{H}-\mathrm{C}$ & * & LL-M & $\mathrm{H}-\mathrm{FI}$ & T3 \\
\hline VL-U & VH-M & VH-C & $\mathrm{H}-\mathrm{U}$ & H-L & $\mathrm{L}-\mathrm{C}$ & H-W & $\mathrm{L}-\mathrm{U}$ & VH-M & $\begin{array}{l}\text { VH- } \\
\text { ML }\end{array}$ & VH-C & $*$ & L-FI & VH-M & $\mathrm{H}-\mathrm{L}$ & $\mathrm{T} 4$ \\
\hline VL-U & $\mathrm{H}-\mathrm{M}$ & $\mathrm{H}-\mathrm{C}$ & VH-L & $\mathrm{L}-\mathrm{U}$ & H-FI & $\begin{array}{l}\text { VH- } \\
\text { ML }\end{array}$ & H-W & $\mathrm{H}-\mathrm{C}$ & VH-C & $*$ & VH-M & VL-L & $\mathrm{H}-\mathrm{U}$ & NO-L & T5 \\
\hline NO-M & VL-FI & VL-M & NO-L & NO-C & $\mathrm{L}-\mathrm{C}$ & VL-FI & $\begin{array}{l}\text { VL- } \\
\text { ML }\end{array}$ & $\mathrm{H}-\mathrm{C}$ & $*$ & $\begin{array}{l}\text { VH- } \\
\text { ML }\end{array}$ & VH-M & VL-L & $\mathrm{H}-\mathrm{U}$ & L-W & T6 \\
\hline H-L & L-ML & L-W & $\mathrm{H}-\mathrm{C}$ & $\mathrm{H}-\mathrm{U}$ & NO-FI & VL-W & $\begin{array}{l}\text { VL- } \\
\text { ML }\end{array}$ & $*$ & VH-L & $\mathrm{H}-\mathrm{M}$ & VH-M & L-M & VH-M & VL-W & $\mathrm{O} 1$ \\
\hline VH-U & VL-FI & $\mathrm{H}-\mathrm{C}$ & VL-M & VL-C & $\mathrm{H}-\mathrm{FI}$ & $\begin{array}{l}\text { VL- } \\
\text { ML }\end{array}$ & $*$ & VL-FI & VL-C & $\mathrm{L}-\mathrm{U}$ & $\mathrm{H}-\mathrm{C}$ & $\mathrm{H}-\mathrm{M}$ & $\mathrm{L}-\mathrm{C}$ & NO-L & $\mathrm{O} 2$ \\
\hline VL-U & L-ML & VL-M & $\mathrm{H}-\mathrm{C}$ & $\mathrm{L}-\mathrm{U}$ & $\mathrm{L}-\mathrm{C}$ & $*$ & $\mathrm{~L}-\mathrm{U}$ & $\begin{array}{l}\text { VL- } \\
\text { ML }\end{array}$ & $\begin{array}{l}\text { VH- } \\
\text { ML }\end{array}$ & $\begin{array}{l}\text { VH- } \\
\text { ML }\end{array}$ & $\mathrm{H}-\mathrm{C}$ & $\mathrm{H}-\mathrm{M}$ & $\mathrm{L}-\mathrm{C}$ & NO-L & O3 \\
\hline L-ML & $\mathrm{H}-\mathrm{M}$ & H-M & NO-C & $\begin{array}{c}\mathrm{NO}- \\
\mathrm{ML}\end{array}$ & $*$ & $\mathrm{NO}-\mathrm{U}$ & $\begin{array}{l}\text { VL- } \\
\text { ML }\end{array}$ & VL-W & VH-FI & $\begin{array}{l}\mathrm{NO}- \\
\mathrm{ML}\end{array}$ & VL-M & $\mathrm{H}-\mathrm{M}$ & VH-L & $\mathrm{H}-\mathrm{U}$ & E1 \\
\hline VH-U & $\begin{array}{l}\text { VH- } \\
\text { ML }\end{array}$ & $\mathrm{VH}-\mathrm{U}$ & $\mathrm{L}-\mathrm{C}$ & * & $\mathrm{H}-\mathrm{U}$ & $\begin{array}{l}\text { VL- } \\
\text { ML }\end{array}$ & $\begin{array}{l}\text { VL- } \\
\text { ML }\end{array}$ & L-M & $\mathrm{NO}-\mathrm{C}$ & $\mathrm{H}-\mathrm{M}$ & VL-M & VL-L & $\mathrm{H}-\mathrm{U}$ & H-ML & E2 \\
\hline $\mathrm{H}-\mathrm{L}$ & H-M & $\mathrm{H}-\mathrm{M}$ & * & VH-C & $\begin{array}{l}\text { VH- } \\
\text { ML }\end{array}$ & L-M & $\begin{array}{l}\text { VL- } \\
\text { ML }\end{array}$ & L-M & H-ML & $\begin{array}{l}\text { VH- } \\
\text { ML }\end{array}$ & VH-M & $\mathrm{L}-\mathrm{W}$ & $\mathrm{H}$ & $\mathrm{L}$ & E3 \\
\hline $\mathrm{H}-\mathrm{L}$ & $\begin{array}{l}\text { VH- } \\
\text { ML }\end{array}$ & * & $\begin{array}{l}\text { VH- } \\
\text { ML }\end{array}$ & VH-C & $\mathrm{H}-\mathrm{U}$ & H-W & $\begin{array}{l}\text { VH- } \\
\text { ML }\end{array}$ & $\mathrm{H}-\mathrm{C}$ & L-ML & $\mathrm{H}-\mathrm{M}$ & $\mathrm{H}-\mathrm{C}$ & $\mathrm{H}-\mathrm{M}$ & $\mathrm{L}-\mathrm{C}$ & VH-M & $\mathrm{L} 1$ \\
\hline H-L & $*$ & $\mathrm{NO}-\mathrm{U}$ & $\begin{array}{l}\text { VH- } \\
\text { ML }\end{array}$ & VH-C & $\mathrm{H}-\mathrm{U}$ & H-W & $\begin{array}{l}\text { VH- } \\
\text { ML }\end{array}$ & $\mathrm{H}-\mathrm{C}$ & H-ML & $\mathrm{L}-\mathrm{U}$ & M & $\mathrm{VH}$ & I & & L2 \\
\hline$*$ & L-ML & $\begin{array}{l}\text { VH- } \\
\text { ML }\end{array}$ & $\begin{array}{l}\text { VH- } \\
\text { ML }\end{array}$ & $\mathrm{H}-\mathrm{L}$ & VH-C & $\mathrm{H}-\mathrm{W}$ & VL-U & L-FI & H-ML & $\mathrm{L}-\mathrm{U}$ & $\mathrm{H}-\mathrm{C}$ & L-FI & $\mathrm{L}-\mathrm{M}$ & L-FI & L3 \\
\hline \multicolumn{16}{|c|}{ Expert 14} \\
\hline NO-L & VH-C & H-ML & L-M & NO-M & L-ML & NO-M & NO-FI & $\mathrm{NO}-\mathrm{C}$ & VL-M & VL-U & NO-FI & H-W & $\mathrm{NO}-\mathrm{C}$ & * & $\mathrm{T} 1$ \\
\hline $\mathrm{L}-\mathrm{C}$ & NO-W & NO-L & $\begin{array}{l}\text { VL- } \\
\text { ML }\end{array}$ & VL-C & NO-U & L-M & VL-FI & L-ML & VL-M & $\mathrm{H}-\mathrm{U}$ & L-FI & L-W & * & L-FI & $\mathrm{T} 2$ \\
\hline NO-L & L-W & L-M & NO-U & $\mathrm{NO}-\mathrm{C}$ & $\begin{array}{l}\mathrm{NO}- \\
\mathrm{ML}\end{array}$ & VL-W & L-M & VL-FI & $\mathrm{H}-\mathrm{U}$ & L-ML & VL-M & * & L-U & L-ML & T3 \\
\hline NO-L & H-W & VH-C & & VL-FI & H-ML & $\mathrm{H}-\mathrm{L}$ & $\mathrm{L}-\mathrm{C}$ & VL-U & $\mathrm{H}-\mathrm{W}$ & L-ML & * & L-ML & VH-C & $I_{-} \mathrm{J}$ & $\mathrm{T} 4$ \\
\hline NO-L & H-W & L-M & $\begin{array}{l}\text { VL- } \\
\text { ML }\end{array}$ & NO-C & $\mathrm{L}-\mathrm{U}$ & L-M & L-M & VL-C & $\mathrm{H}-\mathrm{FI}$ & * & $\mathrm{L}-\mathrm{U}$ & VL-M & H-L & $\mathrm{NO}-\mathrm{C}$ & T5 \\
\hline $\begin{array}{l}\text { NO-L } \\
\text { NO-L }\end{array}$ & $\begin{array}{l}\text { VL-U } \\
\text { VL-U }\end{array}$ & $\begin{array}{l}\text { VL-W } \\
\text { VL-W }\end{array}$ & $\begin{array}{c}\mathrm{NO}-\mathrm{U} \\
\mathrm{H}-\mathrm{C}\end{array}$ & $\begin{array}{l}\text { NO-C } \\
\text { NO-M }\end{array}$ & $\begin{array}{c}\text { L-ML } \\
\text { L-U }\end{array}$ & $\begin{array}{l}\text { VL-W } \\
\text { VL-M }\end{array}$ & & $\begin{array}{l}\text { VL-C } \\
*\end{array}$ & $\begin{array}{c}* \\
\text { VL-M }\end{array}$ & & & & & & $\begin{array}{l}\text { T6 } \\
\text { O1 }\end{array}$ \\
\hline NO-L & L-W & L-M & NO-U & NO-L & $\begin{array}{l}\text { NO- } \\
\text { ML }\end{array}$ & NO-M & $*$ & $\mathrm{NO}-\mathrm{C}$ & NO-L & L-ML & VL-M & VL-M & $\mathrm{L}-\mathrm{U}$ & $\mathrm{NO}-\mathrm{C}$ & $\mathrm{O} 2$ \\
\hline NO-L & VL-U & L-M & L-M & $\begin{array}{l}\text { VL- } \\
\text { ML }\end{array}$ & NO-C & $*$ & $\mathrm{~L}-\mathrm{U}$ & $\mathrm{NO}-\mathrm{C}$ & VL-M & L-ML & VH-W & L-ML & L-U & NO-M & $\mathrm{O} 3$ \\
\hline NO-L & $\mathrm{L}-\mathrm{W}$ & L-M & $\begin{array}{l}\text { VL- } \\
\text { ML }\end{array}$ & NO-M & * & $\mathrm{H}-\mathrm{L}$ & L-FI & VL-L & VL-M & VL-U & VL-M & VL-M & $\mathrm{H}-\mathrm{L}$ & $-M L$ & E1 \\
\hline NO-L & VL-U & L-M & $\begin{array}{l}\text { VL- } \\
\text { ML }\end{array}$ & * & L-ML & NO-M & $\mathrm{L}-\mathrm{L}$ & L-ML & VL-M & VL-U & VL-M & NO-C & $\mathrm{L}-\mathrm{U}$ & VL-C & E2 \\
\hline NO-L & VL-U & VL-W & * & $\begin{array}{l}\text { VL- } \\
\text { ML }\end{array}$ & $\begin{array}{l}\mathrm{NO}- \\
\mathrm{ML}\end{array}$ & NO-M & VL-FI & $\mathrm{NO}-\mathrm{C}$ & NO-L & NO-W & VH-W & $\mathrm{NO}-\mathrm{C}$ & $\mathrm{L}-\mathrm{U}$ & $-M L$ & E3 \\
\hline NO-L & L-W & $*$ & $\mathrm{NO}-\mathrm{U}$ & $\begin{array}{l}\mathrm{NO}- \\
\mathrm{ML}\end{array}$ & NO-W & VL-M & VH-L & VL-W & VL-M & VL-U & $\mathrm{H}-\mathrm{C}$ & VL-M & L-U & H-ML & L1 \\
\hline NO-L & $*$ & NO-L & NO-U & $\begin{array}{l}\text { NO- } \\
\text { ML }\end{array}$ & VL-M & NO-M & VH-L & VH-C & VL-M & VL-U & VH-W & NO-C & IH-C & L-ML & $\mathrm{L} 2$ \\
\hline$*$ & NO-W & NO-L & NO-U & $\begin{array}{l}\text { NO- } \\
\text { ML }\end{array}$ & NO-L & NO-M & L-ML & L-ML & NO-FI & NO-W & L-FI & NO-C & VH-C & VL-C & L3 \\
\hline \multicolumn{16}{|c|}{ Expert 15} \\
\hline NO-L & $\begin{array}{l}\text { VL- } \\
\text { ML }\end{array}$ & NO-FI & $\begin{array}{l}\text { VL- } \\
\text { ML }\end{array}$ & L-L & D-FI & NO-M & $\mathrm{O}-\mathrm{M}$ & $\mathrm{NO}-\mathrm{C}$ & NO-FI & NO-FI & VL-W & VL-L & VL-L & $*$ & $\mathrm{~T} 1$ \\
\hline
\end{tabular}


TABle 15: Continued.

\begin{tabular}{|c|c|c|c|c|c|c|c|c|c|c|c|c|c|c|c|}
\hline 3 & L2 & L1 & E3 & E2 & E1 & 3 & 2 & 01 & 6 & Г5 & $\Gamma 4$ & $\Gamma 3$ & Г2 & T1 & \\
\hline VL-U & NO-FI & NO-W & $\begin{array}{l}\text { VL- } \\
\text { ML }\end{array}$ & VL-L & VL-C & L-FI & $\begin{array}{l}\text { VL- } \\
\text { ML }\end{array}$ & L-U & VL-M & $\mathrm{H}-\mathrm{U}$ & H-ML & L-C & * & L-FI & $\mathrm{T} 2$ \\
\hline NO-L & NO-M & $\mathrm{NO}-\mathrm{W}$ & NO-M & $\mathrm{NO}-\mathrm{U}$ & $\mathrm{NO}-\mathrm{C}$ & VL-M & VL-FI & VL-C & $\mathrm{L}-\mathrm{U}$ & L-L & L-ML & * & H-W & L-U & T3 \\
\hline $\mathrm{H}-\mathrm{M}$ & L-FI & $\mathrm{NO}-\mathrm{U}$ & $\begin{array}{l}\text { NO- } \\
\text { ML }\end{array}$ & L-L & VL-C & VL-W & $\begin{array}{l}\text { VL- } \\
\text { ML }\end{array}$ & $\mathrm{L}-\mathrm{U}$ & $\begin{array}{l}\text { VH- } \\
\text { ML }\end{array}$ & L-W & * & L-ML & VL-L & $\mathrm{L}-\mathrm{U}$ & $\mathrm{T} 4$ \\
\hline $\mathrm{H}-\mathrm{M}$ & $\mathrm{H}-\mathrm{U}$ & NO-W & $\begin{array}{l}\text { VL- } \\
\text { ML }\end{array}$ & $\mathrm{NO}-\mathrm{U}$ & VL-C & VL-U & L-C & VL-FI & $\begin{array}{l}\text { VH- } \\
\text { ML }\end{array}$ & * & L-ML & $\mathrm{L}-\mathrm{U}$ & L-C & NO-W & T5 \\
\hline NO-L & $\mathrm{H}-\mathrm{U}$ & VL-L & NO-FI & L-L & $\mathrm{NO}-\mathrm{C}$ & VL-W & VL-U & $\begin{array}{l}\text { VL- } \\
\text { ML }\end{array}$ & * & VL-C & VH-W & H-ML & H-W & VL-U & T6 \\
\hline$-U$ & L-FI & NO-M & H-L & L-L & VL-C & VL-FI & VL-U & * & $\begin{array}{l}\text { VH- } \\
\text { ML }\end{array}$ & VL-C & H-ML & L-ML & L-C & $\mathrm{L}-\mathrm{U}$ & O1 \\
\hline NO-L & NO-M & L-M & NO-W & NO-U & NO-FI & VL-M & * & VL-L & VL-C & $\mathrm{H}-\mathrm{U}$ & VL-W & VL-L & L-C & NO-W & $\mathrm{O} 2$ \\
\hline VL-U & $\begin{array}{l}\text { NO- } \\
\text { ML }\end{array}$ & NO-C & L-W & $\mathrm{NO}-\mathrm{U}$ & NO-U & $*$ & L-C & NO-C & L-M & VL-C & L-ML & VL-L & VL-L & NO-W & $\mathrm{O} 3$ \\
\hline NO-L & $\mathrm{NO}-\mathrm{U}$ & VL-L & L-W & $\mathrm{NO}-\mathrm{U}$ & $*$ & VL-M & VL-U & VL-C & $\mathrm{H}-\mathrm{W}$ & VL-C & VL-W & VL-L & H-W & L-M & E1 \\
\hline NO-L & L-FI & NO-M & $\begin{array}{l}\text { VL- } \\
\text { ML }\end{array}$ & $*$ & VL-C & VL-M & L-C & VL-U & $\mathrm{H}-\mathrm{W}$ & VH-M & L-ML & $\mathrm{NO}-\mathrm{C}$ & H-W & $\mathrm{H}-\mathrm{C}$ & E2 \\
\hline $\mathrm{VH}-\mathrm{C}$ & $\mathrm{H}-\mathrm{U}$ & VL-L & $*$ & L-L & VL-C & $\mathrm{H}-\mathrm{C}$ & $\begin{array}{l}\text { VL- } \\
\text { ML }\end{array}$ & H-M & $\mathrm{H}-\mathrm{W}$ & H-L & $\mathrm{H}-\mathrm{U}$ & L-ML & $\mathrm{H}-\mathrm{U}$ & $\mathrm{L}-\mathrm{C}$ & E3 \\
\hline $\mathrm{H}-\mathrm{M}$ & NO-L & * & $\mathrm{H}-\mathrm{L}$ & NO-U & NO-C & VL-U & VH-FI & L-U & H-W & H-FI & H-ML & $\mathrm{NO}-\mathrm{U}$ & $\mathrm{H}-\mathrm{M}$ & L-C & L1 \\
\hline NO-L & * & $\mathrm{NO}-\mathrm{U}$ & $\begin{array}{l}\text { NO- } \\
\text { ML }\end{array}$ & $\mathrm{NO}-\mathrm{U}$ & H-ML & NO-M & VH-FI & VH-M & NO-L & $\mathrm{H}-\mathrm{U}$ & VH-W & $\begin{array}{l}\text { NO- } \\
\text { ML }\end{array}$ & H-W & VH-L & L2 \\
\hline * & $\mathrm{NO}-\mathrm{W}$ & $\begin{array}{l}\text { NO- } \\
\text { ML }\end{array}$ & $\mathrm{NO}-\mathrm{C}$ & $\mathrm{NO}-\mathrm{U}$ & VL-C & NO-M & L-C & L-U & $\mathrm{H}-\mathrm{W}$ & L-ML & $\mathrm{H}-\mathrm{U}$ & $\begin{array}{l}\text { NO- } \\
\text { ML }\end{array}$ & H-ML & L-L & L3 \\
\hline \multicolumn{16}{|c|}{ Expert 16} \\
\hline $\begin{array}{l}J \mathrm{H}- \\
\mathrm{ML}\end{array}$ & VH-FI & $\mathrm{H}-\mathrm{C}$ & H-ML & L-M & H-FI & H-L & $\mathrm{NO}$ & L-C & L-M & ML & VH-L & $\mathrm{NO}-\mathrm{U}$ & L-C & * & $\mathrm{T} 1$ \\
\hline VH-U & NO-M & NO-W & H-ML & $\begin{array}{l}\text { VH- } \\
\text { ML }\end{array}$ & L-C & $\mathrm{H}-\mathrm{U}$ & $\begin{array}{l}\text { VL- } \\
\text { ML }\end{array}$ & H-ML & VL-C & H-W & H-M & $\mathrm{H}-\mathrm{L}$ & $*$ & VL-U & $\mathrm{T} 2$ \\
\hline NO-M & NO-L & NO-C & VL-W & H-FI & VL-U & VL-W & L-M & $\begin{array}{l}\text { VL- } \\
\text { ML }\end{array}$ & $\mathrm{H}-\mathrm{C}$ & L-U & ML & $*$ & VH-W & $\begin{array}{l}\text { VL- } \\
\text { ML }\end{array}$ & T3 \\
\hline $\mathrm{H}-\mathrm{L}$ & VH-FI & $\mathrm{VH}-\mathrm{U}$ & L-W & H-ML & VH-M & VH-U & $\mathrm{H}-\mathrm{L}$ & H-ML & VH-U & VH-L & $*$ & L-W & VH-C & & $\mathrm{T} 4$ \\
\hline$-M$ & H-FI & $\mathrm{H}-\mathrm{C}$ & H-ML & L-M & VH-M & $\mathrm{H}-\mathrm{C}$ & H-L & H-ML & $\mathrm{H}-\mathrm{C}$ & * & VH-L & L-W & H-L & ML & T5 \\
\hline VL-M & $\mathrm{L}$ & L-W & VL-W & $\begin{array}{l}\text { VH- } \\
\text { ML }\end{array}$ & $\mathrm{H}$ & VL-I & VH-C & $\begin{array}{l}\text { VL- } \\
\text { ML }\end{array}$ & * & $\mathrm{H}-\mathrm{C}$ & M & H-L & VH-U & $-M$ & T6 \\
\hline $\mathrm{H}-\mathrm{L}$ & VL-U & VL-W & VH-M & $\mathrm{H}-\mathrm{C}$ & $\mathrm{H}-\mathrm{U}$ & VL-V & $\begin{array}{l}\text { VL- } \\
\text { ML }\end{array}$ & * & VH-U & VH-W & $\mathrm{H}-\mathrm{M}$ & ML & $\mathrm{H}-\mathrm{L}$ & L-M & O1 \\
\hline VL-M & VL-U & VL-W & VL-W & $\begin{array}{l}\text { VH- } \\
\text { ML }\end{array}$ & VL-U & NO-M & * & $\mathrm{NO}-\mathrm{U}$ & H-C & $\mathrm{H}-\mathrm{W}$ & V & VH-C & L-C & NO-FI & $\mathrm{O} 2$ \\
\hline NO-M & NO-M & NO-W & L-W & NO-W & NO-C & * & L-M & $\begin{array}{l}\text { VL- } \\
\text { ML }\end{array}$ & L-M & L-U & & ML & $-\mathrm{C}$ & NO-FI & $\mathrm{O} 3$ \\
\hline VH-C & VH-FI & $\mathrm{H}-\mathrm{C}$ & H-ML & H-ML & * & $\mathrm{H}-\mathrm{N}$ & $\mathrm{H}-\mathrm{L}$ & H-ML & $\mathrm{H}-\mathrm{C}$ & $\mathrm{N}$ & & $\mathrm{H}-\mathrm{L}$ & $\mathrm{H}-\mathrm{L}$ & $-M$ & E1 \\
\hline $\mathrm{H}-\mathrm{L}$ & H-F & $\mathrm{H}-\mathrm{C}$ & $\mathrm{L}-\mathrm{W}$ & * & $\mathrm{L}$ & NO & L-N & $\mathrm{L}$ & $\mathrm{H}-\mathrm{C}$ & $\begin{array}{l}\text { VH- } \\
\text { ML }\end{array}$ & $\mathrm{H}-\mathrm{M}$ & $\mathrm{NO}-\mathrm{U}$ & VH-W & H-FI & E2 \\
\hline $\mathrm{H}-\mathrm{U}$ & H-FI & L-W & * & $\begin{array}{l}\text { VH- } \\
\text { ML }\end{array}$ & VH-M & H-ML & $\begin{array}{l}\text { VL- } \\
\text { ML }\end{array}$ & H-ML & VH-U & VH-C & VH-L & $\begin{array}{l}\text { VL- } \\
\text { ML }\end{array}$ & $1-L$ & H-M & E3 \\
\hline VH-FI & VH-FI & * & VH-M & VH-L & VH-M & VH-U & VH-C & VH-FI & $\mathrm{H}-\mathrm{U}$ & ML & $-\mathrm{L}$ & C & VH-W & VH- & L1 \\
\hline VH- & * & VH-U & VH-M & $\begin{array}{l}\text { VH- } \\
\text { ML }\end{array}$ & $M$ & $\mathrm{~V}$ & VH-C & $\mathrm{V}$ & U & $\mathrm{L}$ & $\mathrm{L}$ & C & & & L2 \\
\hline * & H-FI & $\mathrm{H}-\mathrm{C}$ & H-ML & $\mathrm{H}-\mathrm{U}$ & VH-M & H-L & $\begin{array}{l}\text { L-M } \\
\text { Expert }\end{array}$ & $17^{\mathrm{L}-\mathrm{C}}$ & $\mathrm{VH}-\mathrm{U}$ & $\mathrm{H}-\mathrm{W}$ & VH-L & $\mathrm{NO}-\mathrm{U}$ & VH-C & {$[-U$} & L3 \\
\hline L-U & L-C & $\mathrm{H}-\mathrm{U}$ & $\mathrm{H}-\mathrm{C}$ & $\begin{array}{l}\text { VL- } \\
\text { ML }\end{array}$ & M & H-FI & VL-M & 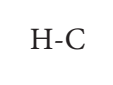 & VL-W & $\mathrm{H}-\mathrm{C}$ & VH-L & L-U & H-FI & * & $\mathrm{T} 1$ \\
\hline L-W & L-C & VL-W & H-L & $\begin{array}{l}\text { VL- } \\
\text { ML }\end{array}$ & VL-L & VL-C & VL-FI & L-M & VL-W & H-FI & $\mathrm{H}-\mathrm{C}$ & VL-W & $*$ & L-ML & $\mathrm{T} 2$ \\
\hline VL-U & $\begin{array}{l}\text { VL- } \\
\text { ML }\end{array}$ & L-U & VL-C & VH-W & VL-FI & VL-L & L-W & VL-U & L-ML & $\mathrm{L}-\mathrm{U}$ & L-C & * & $\begin{array}{l}\text { VL- } \\
\text { ML }\end{array}$ & $\mathrm{H}-\mathrm{U}$ & T3 \\
\hline
\end{tabular}


Table 15: Continued.

\begin{tabular}{|c|c|c|c|c|c|c|c|c|c|c|c|c|c|c|c|}
\hline $\mathrm{L} 3$ & L2 & L1 & E3 & E2 & E1 & $\mathrm{O} 3$ & $\mathrm{O} 2$ & O1 & T6 & T5 & $\mathrm{T} 4$ & T3 & $\mathrm{T} 2$ & $\mathrm{~T} 1$ & \\
\hline VL-FI & H-W & $\mathrm{L}-\mathrm{U}$ & $\mathrm{H}-\mathrm{C}$ & $\mathrm{H}-\mathrm{ML}$ & VL-M & VL-FI & NO-U & NO & $\begin{array}{l}\text { VL- } \\
\text { ML }\end{array}$ & $\mathrm{H}-\mathrm{L}$ & $*$ & $\mathrm{~L}-\mathrm{C}$ & $\begin{array}{l}\text { VL- } \\
\text { ML }\end{array}$ & $\mathrm{H}-\mathrm{W}$ & 14 \\
\hline VL-C & $\begin{array}{l}\text { VL- } \\
\text { ML }\end{array}$ & $\mathrm{H}-\mathrm{U}$ & L-W & $\mathrm{H}-\mathrm{ML}$ & VH-M & NO-C & NO-U & NO-FI & VH-U & * & $\begin{array}{l}\text { VL- } \\
\text { ML }\end{array}$ & L-W & $\begin{array}{l}\text { VL- } \\
\text { ML }\end{array}$ & $\mathrm{H}-\mathrm{L}$ & T5 \\
\hline VL-C & VL-FI & $\mathrm{L}-\mathrm{U}$ & $\mathrm{H}-\mathrm{C}$ & $\begin{array}{l}\text { VL- } \\
\text { ML }\end{array}$ & $\begin{array}{l}\text { NO- } \\
\text { ML }\end{array}$ & $\mathrm{NO}-\mathrm{C}$ & NO-U & VL-U & * & LL-M & $\mathrm{H}-\mathrm{C}$ & $\mathrm{H}-\mathrm{L}$ & L-W & I-ML & T6 \\
\hline $\mathrm{L}-\mathrm{C}$ & $\begin{array}{l}\text { VL- } \\
\text { ML }\end{array}$ & $\mathrm{L}-\mathrm{U}$ & $\mathrm{H}-\mathrm{M}$ & L-U & VL-M & $\mathrm{NO}-\mathrm{C}$ & NO-U & * & $\mathrm{H}-\mathrm{C}$ & $\mathrm{L}-\mathrm{U}$ & $\mathrm{H}-\mathrm{C}$ & L-W & L-W & $\mathrm{H}-\mathrm{ML}$ & $\mathrm{O} 1$ \\
\hline VL-W & VL-L & $\mathrm{H}-\mathrm{U}$ & VL-C & $\begin{array}{l}\text { VL- } \\
\text { ML }\end{array}$ & H-M & NO-C & * & VL-U & VL-U & L-U & $\begin{array}{l}\text { VL- } \\
\text { ML }\end{array}$ & H-L & $\begin{array}{l}\text { VL- } \\
\text { ML }\end{array}$ & $-M L$ & $\mathrm{O} 2$ \\
\hline $\mathrm{VH}-\mathrm{C}$ & L-C & VL-W & H-W & $\mathrm{L}-\mathrm{U}$ & $\mathrm{L}-\mathrm{C}$ & $*$ & VL-M & $\mathrm{H}-\mathrm{C}$ & L-ML & $\mathrm{H}-\mathrm{M}$ & VH-L & VL-W & H-FI & VL-M & $\mathrm{O} 3$ \\
\hline VL-M & VL-C & L-U & NO-M & $\mathrm{NO}-\mathrm{C}$ & * & H-FI & L-W & $\mathrm{H}-\mathrm{C}$ & $\mathrm{VH}-\mathrm{U}$ & VL-M & $\begin{array}{l}\text { VL- } \\
\text { ML }\end{array}$ & VL-W & $\begin{array}{l}\text { VL- } \\
\text { ML }\end{array}$ & L-ML & E1 \\
\hline $\mathrm{L}-\mathrm{U}$ & L-C & VI_W & L-W & * & H-M & $\begin{array}{l}\text { VL- } \\
\text { ML }\end{array}$ & NO-U & VL-U & L-ML & $\mathrm{H}-\mathrm{C}$ & $\begin{array}{l}\text { VL- } \\
\text { ML }\end{array}$ & N & L-W & IL & E2 \\
\hline L-ML & H-W & L-W & $*$ & $\mathrm{H}-\mathrm{ML}$ & VL-M & VL-C & NO-W & NO-FI & VH-U & $\mathrm{H}-\mathrm{M}$ & $\mathrm{H}-\mathrm{C}$ & VL-W & H-FI & L-ML & E3 \\
\hline VL-M & L-C & * & L-W & $\mathrm{H}-\mathrm{I}$ & $\mathrm{L}-\mathrm{C}$ & H-FI & $\mathrm{L}-\mathrm{W}$ & $\mathrm{L}$ & $\mathrm{H}-\mathrm{C}$ & L- & $\mathrm{H}-\mathrm{C}$ & $\mathrm{H}$ & H-FI & L-ML & L1 \\
\hline $\mathrm{L}-\mathrm{U}$ & * & VL-W & VL-C & $\mathrm{L}-\mathrm{U}$ & L-C & $\begin{array}{l}\text { NO- } \\
\text { ML }\end{array}$ & $\mathrm{NO}$ & $\mathrm{H}-\mathrm{C}$ & $\mathrm{H}-\mathrm{C}$ & 1 & $\mathrm{I}$ & $\mathrm{H}$ & H-FI & $\begin{array}{l}\text { VH- } \\
\text { ML }\end{array}$ & L2 \\
\hline * & $\mathrm{H}-\mathrm{M}$ & $\mathrm{H}-\mathrm{C}$ & VL-M & L-U & H-FI & H-M & $\begin{array}{l}\text { VL-L } \\
\text { Expert }\end{array}$ & VL-C & L-M & H-ML & VH-U & NO-L & $\mathrm{VH}-\mathrm{U}$ & $\mathrm{H}-\mathrm{M}$ & L3 \\
\hline VH-U & VH-W & $\mathrm{H}-\mathrm{W}$ & VH-FI & VH-C & $\mathrm{L}-\mathrm{U}$ & NO-FI & VL-M & VL-M & L-W & $\mathrm{L}-\mathrm{C}$ & VH-L & N & H-L & * & $\mathrm{T} 1$ \\
\hline H-FI & L-U & L-L & H-ML & $\mathrm{NO}-\mathrm{U}$ & $\mathrm{O}-\mathrm{W}$ & VL-FI & $\mathrm{L}-\mathrm{U}$ & L- & $\begin{array}{l}\text { VL- } \\
\text { ML }\end{array}$ & $\mathrm{H}_{-}$ & H-W & $\mathrm{H}-$ & * & & $\mathrm{T} 2$ \\
\hline NO-U & NO-W & $\begin{array}{l}\mathrm{NO}- \\
\mathrm{ML}\end{array}$ & $\mathrm{H}-\mathrm{ML}$ & $\mathrm{L}-\mathrm{W}$ & VL-U & VL-L & VL-L & $\begin{array}{l}\mathrm{V} \\
\mathrm{M}\end{array}$ & VL-U & H-ML & H-W & * & VH-C & VL-U & T3 \\
\hline H-ML & VH-M & VH-C & $\mathrm{H}-\mathrm{U}$ & H-L & $\mathrm{V}-2$ & $-M$ & $\mathrm{~L}$ & VH-L & H-M & $\mathrm{NO}-\mathrm{U}$ & * & L- & $\begin{array}{l}\text { VH- } \\
\text { ML }\end{array}$ & $N$ & T4 \\
\hline $\mathrm{L}-\mathrm{U}$ & $\mathrm{H}-\mathrm{C}$ & $\mathrm{H}-\mathrm{U}$ & VH-FI & L-W & $\mathrm{H}-\mathrm{M}$ & VH-FI & $\mathrm{H}-\mathrm{L}$ & H-M & VH-M & * & VH-L & $\mathrm{V}$ & $\mathrm{H}-\mathrm{L}$ & $\mathrm{NO}-\mathrm{W}$ & T5 \\
\hline VH-U & L-U & L-L & $\mathrm{H}-\mathrm{C}$ & $\mathrm{H}-\mathrm{FI}$ & $\begin{array}{l}\text { VL- } \\
\text { ML }\end{array}$ & VL-C & VL-FI & $\mathrm{H}-\mathrm{M}$ & * & H-W & VH-L & $\begin{array}{l}\text { VI } \\
\text { M }\end{array}$ & $\mathrm{H}-\mathrm{L}$ & $\mathrm{U}$ & T6 \\
\hline $\mathrm{H}-\mathrm{U}$ & $\mathrm{I}_{\mathrm{IU}} \mathrm{U}$ & $\mathrm{I}_{-} \mathrm{I}$ & H-ML & $\mathrm{H}-\mathrm{ML}$ & $\mathrm{NO}$ & VL-U & VL-W & * & VH-M & VH-W & VH-L & $\mathrm{I}$ & $\begin{array}{l}\text { VH- } \\
\text { ML }\end{array}$ & U & $\mathrm{O} 1$ \\
\hline $\mathrm{NO}-\mathrm{U}$ & VL-M & VL-FI & L-M & H-I & VL-C & VL-U & * & VL-M & VL-FI & VL-M & $\mathrm{H}-\mathrm{U}$ & $\mathrm{H}-\mathrm{FI}$ & L-W & $\mathrm{NO}-\mathrm{W}$ & $\mathrm{O} 2$ \\
\hline VL-C & NO-W & $\begin{array}{l}\text { NO- } \\
\mathrm{ML}\end{array}$ & VL-L & VL-W & NO-W & * & NO-W & VL-U & VL-C & L-C & H-M & $\begin{array}{l}\text { VL- } \\
\text { ML }\end{array}$ & L-W & $-W$ & $\mathrm{O} 3$ \\
\hline $\mathrm{L}-\mathrm{U}$ & $\mathrm{H}-\mathrm{C}$ & $\mathrm{H}-\mathrm{U}$ & NO-FI & $\mathrm{NO}-\mathrm{U}$ & * & I & VL-M & $\mathrm{VH}$ & L-M & 1 & 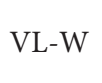 & VL- & $-M L$ & $\mathrm{~L}$ & E1 \\
\hline VH-U & VH-U & $\begin{array}{l}\text { VH- } \\
\text { ML }\end{array}$ & L-M & $*$ & $-M$ & VL-C & VI & -MI & $\mathrm{H}-\mathrm{C}$ & $\begin{array}{l}\mathrm{V} \\
\mathrm{M}\end{array}$ & $\mathrm{T}$ & L-V & [-ML & $H$ & E2 \\
\hline H-ML & & $\mathrm{H}-\mathrm{U}$ & $*$ & & & & $\mathrm{~L}-\mathrm{U}$ & & st & & & $\mathrm{H}-\mathrm{I}$ & & & 3 \\
\hline H-ML & VH_I & $*$ & 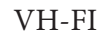 & V & $\mathrm{L}$ & $\mathrm{H}-\mathrm{M}$ & VH-L & $x$ & I & $11-\mathrm{C}$ & $\mathrm{L}$ & I & $\mathrm{L}$ & & L1 \\
\hline H-ML & * & $\begin{array}{l}\mathrm{NO}- \\
\mathrm{ML}\end{array}$ & VH-FI & VH-C & H-M & $\mathrm{H}-\mathrm{M}$ & VH-L & H-M & $\mathrm{H}-\mathrm{FI}$ & L-C & VH-L & $\begin{array}{l}\text { VH- } \\
\text { ML }\end{array}$ & $\mathrm{H}-\mathrm{L}$ & VH-M & $\mathrm{L} 2$ \\
\hline * & L-U & $\mathrm{H}-\mathrm{U}$ & H-ML & VH-C & $\mathrm{H}-\mathrm{N}$ & $L-C+C$ & $\begin{array}{l}\text { L-ML } \\
\text { Expert }\end{array}$ & H-M & H-FI & $\mathrm{L}-\mathrm{C}$ & H-L & VL- & L-W & $\mathrm{L}$ & L3 \\
\hline $\begin{array}{l}-\mathrm{M} \\
\mathrm{H}-\mathrm{U}\end{array}$ & $\begin{array}{l}\mathrm{H}-\mathrm{U} \\
\mathrm{ML}\end{array}$ & L-W & $-M$ & VL-C & FI & $\mathrm{Vl}$ & $\begin{array}{c}\text { VH-L } \\
\text { H-C }\end{array}$ & & L-U & & $\mathrm{L}-$ & & $\begin{array}{c}\text { L-ML } \\
*\end{array}$ & $\begin{array}{r}* \\
\mathrm{VH}-\end{array}$ & $\begin{array}{l}\mathrm{T} 1 \\
\mathrm{~T} 2\end{array}$ \\
\hline $\begin{array}{l}\mathrm{NO}- \\
\mathrm{ML}\end{array}$ & NO-L & NO-U & $\mathrm{H}-\mathrm{W}$ & L-U & VL-FI & VL-U & VL-L & VL-C & VL-FI & $\Pi-U$ & H-ML & $*$ & VH-U & $L-\mathrm{W}$ & $\mathrm{T} 3$ \\
\hline $\mathrm{H}-\mathrm{M}$ & $\mathrm{H}-\mathrm{M}$ & VH-C & $T$ & $\mathrm{HI}$ & $\mathrm{I}$ & H-M & L-L & $\begin{array}{l}\text { VH- } \\
\text { ML }\end{array}$ & VH-U & $W$ & * & $\mathrm{H}-\mathrm{C}$ & VH-U & $\mathrm{H}-\mathrm{M}$ & $\mathrm{T} 4$ \\
\hline L-M & $-M$ & $\mathrm{H}-\mathrm{C}$ & VH-L & L-U & H-FI & VH-W & $\mathrm{H}-\mathrm{C}$ & H-W & VH-U & $*$ & VH-U & VL-L & $\mathrm{H}-\mathrm{L}$ & NO-W & T5 \\
\hline $\begin{array}{l}\text { NO- } \\
\mathrm{ML}\end{array}$ & L-FI & L-M & $\mathrm{O}-\mathrm{L}$ & $\mathrm{O}-\mathrm{C}$ & I & II & VL-L & VL-C & * & L-L & $\mathrm{H}-$ & $-\mathrm{L}$ & H-L & $v$ & T6 \\
\hline $\begin{array}{l}\mathrm{H}-\mathrm{M} \\
\text { VI-W }\end{array}$ & ML & w & $-M$ & $\mathrm{H}-\mathrm{U}$ & NO-FI & VL-M & VL-L & * & VH-U & 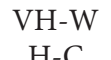 & $\mathrm{VI}$ & $\mathrm{H}$ & $\mathrm{H}-\mathrm{U}$ & & O1 \\
\hline$V L-W$ & VL-FI & - & VL-N1 & & -1 & & & & VI I I & & - & $\mathrm{H}$ & $V \mathrm{~L}-\mathrm{U}$ & L-W & $\mathrm{O} 2$ \\
\hline
\end{tabular}


TABle 15: Continued.

\begin{tabular}{|c|c|c|c|c|c|c|c|c|c|c|c|c|c|c|c|}
\hline L3 & L2 & L1 & E3 & E2 & E1 & $\mathrm{O} 3$ & $\mathrm{O} 2$ & $\mathrm{O} 1$ & T6 & T5 & T4 & T3 & $\mathrm{T} 2$ & $\mathrm{~T} 1$ & \\
\hline $\mathrm{VH}-\mathrm{U}$ & L-ML & VL-M & $\mathrm{H}-\mathrm{C}$ & $\mathrm{L}-\mathrm{U}$ & L-C & $*$ & L-L & $\mathrm{H}-\mathrm{W}$ & VH-W & $\mathrm{VH}-\mathrm{U}$ & L-W & $\begin{array}{l}\text { VL- } \\
\text { ML }\end{array}$ & H-L & VL-C & $\mathrm{O} 3$ \\
\hline L-M & H-M & $\mathrm{H}-\mathrm{C}$ & NO-L & NO-C & $*$ & NO-FI & VL-L & VL-C & L-C & VL-W & $\mathrm{H}-\mathrm{C}$ & L-W & $\mathrm{H}-\mathrm{L}$ & H-M & E1 \\
\hline $\mathrm{VH}-\mathrm{U}$ & $\begin{array}{l}\text { VH- } \\
\text { ML }\end{array}$ & VH-W & L-C & $*$ & H-FI & VL-M & VL-L & L-M & $\mathrm{H}-\mathrm{C}$ & VH-U & VL-L & L-W & H-L & H-M & E2 \\
\hline $\mathrm{H}-\mathrm{M}$ & H-M & $\mathrm{H}-\mathrm{C}$ & * & VH-U & VH-W & L-M & VL-L & $\mathrm{H}-\mathrm{U}$ & $\mathrm{H}-\mathrm{W}$ & $\begin{array}{l}\text { VH- } \\
\text { ML }\end{array}$ & $\mathrm{H}-\mathrm{C}$ & L-ML & H-M & $\mathrm{H}-\mathrm{C}$ & E3 \\
\hline H-M & $\begin{array}{l}\text { VH- } \\
\text { ML }\end{array}$ & * & VH-L & VH-U & H-FI & $\mathrm{H}-\mathrm{M}$ & VH-L & $\mathrm{H}-\mathrm{U}$ & $\mathrm{H}-\mathrm{W}$ & $\begin{array}{l}\text { VH- } \\
\text { ML }\end{array}$ & $\mathrm{H}-\mathrm{C}$ & H-ML & L-U & VH-M & L1 \\
\hline VH-U & * & VH-W & VH-L & VH-U & VH-FI & VH-W & VH-L & VH-U & $\mathrm{H}-\mathrm{C}$ & L-M & L-W & L-ML & VH-U & VH-L & L2 \\
\hline * & H-M & $\mathrm{H}-\mathrm{C}$ & VL-M & L-U & H-FI & $\mathrm{H}-\mathrm{M}$ & $\begin{array}{l}\text { VL-L } \\
\text { Expert }\end{array}$ & $\begin{array}{l}\text { VL-C } \\
20\end{array}$ & L-M & H-ML & $\mathrm{VH}-\mathrm{U}$ & NO-L & $\mathrm{VH}-\mathrm{U}$ & H-M & L3 \\
\hline
\end{tabular}

influenced and the operational and legal categories are predominantly influential levels. This means that there should be more control over operational and legal challenges so that controlling them could have a positive impact on the challenges of the other two categories.

In the two diagrams above, it is clear that the challenges regarding the law are the most influential, while the weight of the technological challenges is greater than the others. It is concluded that we must first pay close attention to effective legitimate challenges so that these challenges can have a positive impact on technology challenges, which have significant weight.

\section{Conclusion and Future Recommendations}

This paper proposes the following three steps for implementing BIM in developing countries:

(1) Providing basic infrastructure such as hardware, software, and training

(2) Implementing the technology, locally and appropriately for each country

(3) Establishing a legal system to support proper and effective implementation

The reason why we emphasize on developing countries so much is because the conditions in regards to lack of infrastructures for implementing BIM would be similar to the case study given in this paper. In most developing countries, much similar to the results of our case study showed for Iran, the need for proper education remains the main challenge for implementation of BIM, whereas in the well-developed countries, this might not be considered as a serious challenge in the first place. On the contrary, however, the most developing countries struggle to keep track, and it might take longer to fully adhere new systems. Despite the emergence of BIM in many developing countries, there are still some misunderstandings regarding this technology, and the conceptual transfer has not been fully executed. As it is clear, the first step to implement any new technology is to comprehensively define various facets of its implementation, which is also vital to the subsequent steps. The second challenge is the lack of upstream organizations' (or in some cases governmental) supports. The next major challenge, which is the absence of appropriate legislation, may also lead to failure, loss of time, and financial resources, which can also be considered a subset of the third step mentioned above. Another aspect of this assertion could be the extent of the impact. Lack of upstream organizations' support is clearly the most influential of all challenges, the complete relationships of which with all of the challenges are outlined in the graph. This challenge was also addressed as the most important challenge, showing that the extent of organizational support for implementing this technology in the country affects all other aspects considerably. According to the scatter chart and other calculations, teamwork and interacting with people involved in the project is the most influenced challenge. The reason behind this susceptibility is the fact that any unconventional and unprofessional behaviors have the potential to affect one's morale and performance, as well as their willingness to work in a team and interact with colleagues. The same could be said for interface-related issues. As a result, this challenge can be related to all the mentioned steps. On the contrary, the first step is to train and provide the infrastructure that can influence the tendency for teamwork. The second step, the proper implementation of technology, can have a significant impact on the extent to which people involved in the project interact and are perceived. Finally, there was clearly a lack of support and well-established laws and regulations to pressure individuals into doing interactive work. The sanctions imposed on the purchase and use of key BIM features is also a hindering factor for some developing countries. This challenge also affects the staff's motivation, basic misunderstandings of the technology, and costs. Finally, according to the studies reviewed and the existing gaps, identifying the countries that have experienced successful BIM implementation, reviewing their adopted strategies for implementing this technology correctly, prioritizing them, and determining their effectiveness in implementation would be useful for future research.

\section{Appendix}

\section{A. Questionnaire (1)}

The Questionnaire (1) is described in Table 14 


\section{B. Questionnaire (2)}

The Questionnaire (2) is described in Table 15.

\section{Data Availability}

The data used to support the findings of this study are included within the article in the Appendix section.

\section{Conflicts of Interest}

The authors declare that they have no conflicts of interest regarding the publication of this article.

\section{References}

[1] S. Rokooei, "Building information modeling in project management: necessities, challenges and outcomes," Procedia-Social and Behavioral Sciences, vol. 210, pp. 87-95, 2015.

[2] A. Rezahoseini, S. Noori, S. F. Ghannadpour, and M. Bodaghi, "Investigating the effects of building information modeling capabilities on knowledge management areas in the construction industry," Journal of Project Management, vol. 4, no. 1, pp. 1-18, 2019.

[3] C. M. Eastman, P. Teicholz, R. Sacks, K. Liston, and B. Handbook, A Guide to Building Information Modeling for Owners, Managers, Architects, Engineers, Contractors, and Fabricators, John Wiley \& Sons, Hoboken, NJ, USA, 2008.

[4] A. Fazli, S. Fathi, M. H. Enferadi, M. Fazli, and B. Fathi, "Appraising effectiveness of building information management (BIM) in project management," Procedia Technology, vol. 16, pp. 1116-1125, 2014.

[5] K. Ullah, I. Lill, and E. Witt, "An overview of BIM adoption in the construction industry: benefits and barriers," in Proceedings of the 10th Nordic Conference on Construction Economics and Organization, Emerald Publishing Limited, May 2019, Tallinn, Estonia.

[6] H. Liu and Q. Liu, Research on the Development Barriers of BIM in China, Applied Mechanics and Materials, Trans Tech Publications, Freienbach, Switzerland, 2014.

[7] B. McAuley, A. Hore, and R. West, "BICP global BIM studylessons for Ireland's BIM programme," 2017, https://www. stroma.com/news/global-bim.

[8] S. Paul, "BIM adoption around the world: how good are we? Geospatialworld," 2019, https://www.geospatialworld.net/ article/bim-adoption-around-the-world-how-good-are-we/.

[9] D. W. Chan, T. O. Olawumi, and A. M. Ho, Critical Success Factors for Building Information Modelling (BIM) Implementation in Hong Kong, Engineering, Construction and Architectural Management, Emerald Publishing Limited, Bingley, UK, 2019.

[10] R. Lahdou and D. Zetterman, BIM for Project Managers How Project Managers Can Utilize BIM in Construction Projects, Chalmers University of Technology, Gothenburg, Sweden, 2011.

[11] Y. Liu, S. Van Nederveen, and M. Hertogh, "Understanding effects of BIM on collaborative design and construction: an empirical study in China," International Journal of Project Management, vol. 35, no. 4, pp. 686-698, 2017.

[12] G. Brewer, T. Gajendran, and R. Le Goff, "Building information modelling (BIM): an introduction and international perspectives (research report)," 2012.

[13] B. A. Brucker, M. P. Case, E. W. East et al., Building Information Modeling (BIM): A Road Map for Implementation to
Support MILCON Transformation and Civil Works Projects within the US Army Corps of Engineers, Construction Engineering Research Lab (Army), Champaign, IL, USA, 2006.

[14] M. Bew and M. Richards, "BIM maturity model, construct IT autumn 2008 members' meeting, Brighton, UK," 2008.

[15] H. Yan and P. Demian, Benefits and Barriers of Building Information Modelling, Loughborough University, Loughborough, UK, 2008.

[16] J. M. Taylor, J. Liu, and M. F. Hein, "Integration of building Information modeling (BIM) into an ACCE accredited construction management curriculum," in Proceedings of the 44th Annual Conference by Associated Schools of Construction, Auburn University. Citeseer, Auburn, AL, USA, April 2008.

[17] B. Succar, "Building information modelling framework: a research and delivery foundation for industry stakeholders," Automation in Construction, vol. 18, no. 3, pp. 357-375, 2009.

[18] F. J. Sabongi and M. Arch, "The Integration of BIM in the Undergraduate Curriculum: an analysis of undergraduate courses," in Proceedings of the 45th ASC Annual Conference (the Associated Schools of Construction), pp. 1-4, Gainesville, FL, USA, April 2009.

[19] A. Sharag-Eldin and N. O. Nawari, "BIM in AEC education," in Proceedings of the Structures Congress 2010, pp. 1676-1688, Orlando, FL, USA, May 2010.

[20] C. M. Clevenger, M. Ozbek, S. Glick, and D. Porter, "Integrating BIM into construction management education," in Proceedings of the EcoBuild BIM-Related Academic Workshop, Washington, DC, USA, December 2010.

[21] R. Sacks and R. Barak, "Teaching building information modeling as an integral part of freshman year civil engineering education," Journal of Professional Issues in Engineering Education and Practice, vol. 136, no. 1, pp. 30-38, 2010.

[22] K.-D. A. Wong, F. K. Wong, and A. Nadeem, "Building information modelling for tertiary construction education in Hong Kong," Journal of Information Technology in Construction, vol. 16, pp. 467-476, 2011.

[23] S. Azhar, "Building information modeling (BIM): trends, benefits, risks, and challenges for the AEC industry," Leadership and Management in Engineering, vol. 11, no. 3, pp. 241-252, 2011.

[24] M. M. Joannides, S. Olbina, and R. R. A. Issa, "Implementation of building information modeling into accredited programs in architecture and construction education," International Journal of Construction Education and Research, vol. 8, no. 2, pp. 83-100, 2012.

[25] R. Sacks and E. Pikas, "Building information modeling education for construction engineering and management I: industry requirements, state of the art, and gap analysis," Journal of Construction Engineering and Management, vol. 139, no. 11, Article ID 04013016, 2013.

[26] D. Bryde, M. Broquetas, and J. M. Volm, "The project benefits of building information modelling (BIM)," International Journal of Project Management, vol. 31, no. 7, pp. 971-980, 2013.

[27] H. Lindblad, Study of the Implementation Process of BIM in Construction Projects, Chalmers University of Technology, Gothenburg, Sweden, 2013.

[28] S. Fox, "Getting real about BIM," International Journal of Managing Projects in Business, vol. 7, no. 3, pp. 405-422, 2014.

[29] R. M. Zhou, Application Analysis of BIM in China Zun Foundation Project, Applied Mechanics and Materials, Trans Tech Publications Ltd., Freienbach, Switzerland, 2014. 
[30] N. Nawari, T. Chichugova, S. Mansoor, and L. Delfin, BIM in Structural Design Education, Computing in Civil and Building Engineering, American Society of Civil Engineers, Reston, VA, USA, 2014.

[31] N. O. Nawari and A. Alsaffar, "BIM education: a framework for Kuwait," in Proceedings of the 14th International Conference on Construction Applications of Virtual Reality, Sharjah, UAE, November 2014.

[32] W. Lee, S. Kang, R. Moh, R. Wu, H. Hsieh, and Z. Shu, "Application of BIM coordination technology to HSR Changhua station," Visualization in Engineering, vol. 3, no. 1, p. $5,2015$.

[33] F. H. Abanda, J. H. M. Tah, and F. K. T. Cheung, "BIM in offsite manufacturing for buildings," Journal of Building Engineering, vol. 14, pp. 89-102, 2017.

[34] E. Alreshidi, M. Mourshed, and Y. Rezgui, "Factors for effective BIM governance," Journal of Building Engineering, vol. 10, pp. 89-101, 2017.

[35] A. H. Abd Jamil and M. S. Fathi, "Contractual challenges for BIM-based construction projects: a systematic review," Built Environment Project and Asset Management, vol. 8, no. 4, pp. 372-385, 2018.

[36] A. Marefat, H. Toosi, and R. Mahmoudi Hasankhanlo, "A BIM approach for construction safety: applications, barriers and solutions," Engineering, Construction and Architectural Management, vol. 26, no. 9, pp. 1855-1877, 2018.

[37] T. Almuntaser, M. O. Sanni-Anibire, and M. A. Hassanain, "Adoption and implementation of BIM-case study of a Saudi Arabian AEC firm," International Journal of Managing Projects in Business, vol. 11, no. 3, pp. 608-624, 2018.

[38] P. G. P. Sabet and H.-Y. Chong, "Interactions between building information modelling and off-site manufacturing for productivity improvement," International Journal of Managing Projects in Business, vol. 13, pp. 233-255, 2019.

[39] P. G. P. Sabet and H.-Y. Chong, "Interactions between building information modelling and off-site manufacturing for productivity improvement," International Journal of Managing Projects in Business, vol. 13, no. 2, pp. 233-255, 2019.

[40] E. Sackey, M. M. Tuuli, and A. R. Dainty, "expansive learning in contemporary construction organisations," Built Environment Project and Asset Management, vol. 9, no. 3, pp. 383-398, 2019.

[41] K. B. Blay, M. M. Tuuli, and J. France-Mensah, "Managing change in BIM-level 2 projects: benefits, challenges, and opportunities," Built Environment Project and Asset Management, vol. 9, no. 5, pp. 581-596, 2019.

[42] E. O. Oyewole and J. O. Dada, "Training gaps in the adoption of building information modelling by Nigerian construction professionals," Built Environment Project and Asset Management, vol. 9, no. 3, pp. 399-411, 2019.

[43] S. F. Ghannadpour, A. RezaHoseini, S. Noori, and M. Yazdani, "Analyzing the influence of building information modeling (BIM) on construction project management areas of knowledge: using a hybrid FANP-FVIKOR approach," International Journal of Industrial Engineering \& Production Research, vol. 30, no. 1, pp. 57-92, 2019.

[44] A. Rezahoseini, S. Noori, S. F. Ghannadpour, and M. Bodaghi, "Reducing rework and increasing the civil projects quality, through total quality management (TQM), by using the concept of building information modeling (BIM)," Journal of Industrial and Systems Engineering, vol. 12, 2019.

[45] C. T. Chan, "Barriers of implementing BIM in construction industry from the designers' perspective: a Hong Kong experience," Journal of System and Management Sciences, vol. 4, no. 2, pp. 24-40, 2014.

[46] A. Redmond, A. Hore, M. Alshawi, and R. West, "Exploring how information exchanges can be enhanced through cloud BIM," Automation in Construction, vol. 24, pp. 175-183, 2012.

[47] B. McAuley, A. Hore, and R. West, "Building information modelling in Ireland 2017," 2017.

[48] A. Aibinu and S. Venkatesh, "Status of BIM adoption and the BIM experience of cost consultants in Australia," Journal of Professional Issues in Engineering Education and Practice, vol. 140, no. 3, Article ID 04013021, 2013.

[49] B. Gilligan and J. Kunz, "VDC use in 2007: significant value, dramatic growth, and apparent business opportunity," 2007.

[50] A. Kiviniemi, J. Karlshøj, V. Tarandi, H. Bell, and O. J. Karud, "Review of the development and implementation of IFC compatible BIM," 2008.

[51] L. Á. Antón and J. Díaz, "Integration of LCA and BIM for sustainable construction," International Journal of Social, Behavioral, Educational, Economic, Business and Industrial Engineering, vol. 8, no. 5, pp. 1378-1382, 2014.

[52] L. Aryani Ahmad and S. Mohd, "Application of building information modeling (BIM) in the Malaysian construction industry: a story of the first government project," Applied Mechanics and Materials, vol. 773, 2015.

[53] R. A. Kivits and C. Furneaux, "BIM: enabling sustainability and asset management through knowledge management," The Scientific World Journal, vol. 2013, Article ID 983721, 14 pages, 2013.

[54] M. Abubakar, Y. Ibrahim, D. Kado, and K. Bala, "contractors' perception of the factors affecting building information modelling (BIM) adoption in the Nigerian construction industry," Computing in Civil and Building Engineering, vol. 2014, pp. 167-178, 2014.

[55] A. Ganah and G. A. John, "An overview of the feasibility of achieving level 2 building information modeling by 2016 in the UK," Journal of Civil Engineering and Architecture, vol. 9, no. 8, pp. 885-894, 2015.

[56] A. Q. Sahil, Adoption of Building Information Modeling in Developing Countries: A Phenomenological Perspective, Colorado State University, Fort Collins, CO, USA, 2016.

[57] K. Park and K. Kim, "BIM application and adoption in the UK housing sector," Integrated Building Information Modelling, pp. 46-81, Bentham Science, Sharjah, UAE, 2017.

[58] A. Nanajkar and Z. Gao, "BIM implementation practices at India's AEC firms," ICCREM 2014: Smart Construction and Management in the Context of New Technology, pp. 134-139, CRC Press, Boca Raton, FL, USA, 2014.

[59] J. Rogers, H.-Y. Chong, and C. Preece, "Adoption of building information modelling technology (BIM)," Engineering, Construction and Architectural Management, vol. 22, no. 4, pp. 424-445, 2015.

[60] S. X. Zhang and Y. R. Hu, "The analysis of barriers of development of China's construction industry BIM," Advanced Materials Research, pp. 3119-3122, Trans Tech Publications Ltd., Freienbach, Switzerland, 2014.

[61] J. Boktor, A. Hanna, and C. C. Menassa, "State of practice of building information modeling in the mechanical construction industry," Journal of Management in Engineering, vol. 30, no. 1, pp. 78-85, 2013.

[62] McGraw-Hill Construction, Building Information Modeling: Transforming Design and Construction to Achieve Greater Industry Productivity, McGraw-Hill Construction, New York, NY, USA, 2008. 
[63] K.-U. Ahn, Y.-J. Kim, C.-S. Park, I. Kim, and K. Lee, "BIM interface for full vs. semi-automated building energy simulation," Energy and Buildings, vol. 68, pp. 671-678, 2014.

[64] N. Gu and K. London, "Understanding and facilitating BIM adoption in the AEC industry," Automation in Construction, vol. 19, no. 8, pp. 988-999, 2010.

[65] C. S. Dossick and G. Neff, "Organizational divisions in BIMenabled commercial construction," Journal of Construction Engineering and Management, vol. 136, no. 4, pp. 459-467, 2009.

[66] L. W. Adamus, "BIM: interoperability for sustainability analysis in construction," in Proceedings of the Central Europe towards Sustainable Building: Integrated Building Design BIM, pp. 1-4, Europe, 2013.

[67] N. A. A. Ismail, M. Chiozzi, and R. Drogemuller, "An overview of BIM uptake in Asian developing countries," 2017, Article ID 080008

[68] A. Hanna, F. Boodai, and M. El Asmar, "State of practice of building information modeling in mechanical and electrical construction industries," Journal of Construction Engineering and Management, vol. 139, no. 10, Article ID 04013009, 2013.

[69] P. Abolghasemzadeh, "A comprehensive method for environmentally sensitive and behavioral microscopic egress analysis in case of fire in buildings," Safety Science, vol. 59, pp. 1-9, 2013.

[70] O. O. Akinade, L. O. Oyedele, S. O. Ajayi et al., "Design for Deconstruction (DfD): critical success factors for diverting end-of-life waste from landfills," Waste Management, vol. 60, pp. 3-13, 2017.

[71] A. Hope and Z. Alwan, "Building the future: integrating building information management and environmental assessment methodologies," 2012.

[72] A. Enshassi, L. AbuHamra, and S. Mohamed, "Barriers to implementation of building information modelling (BIM) in the Palestinian construction industry," International Journal of Construction Project Management, vol. 8, no. 2, p. 103, 2016.

[73] P. Bosch-Sijtsema, A. Isaksson, M. Lennartsson, and H. C. Linderoth, "Barriers and facilitators for BIM use among Swedish medium-sized contractors-"We wait until someone tells us to use it"' Visualization in Engineering, vol. 5, no. 1, p. 3, 2017.

[74] E. Sackey, M. Tuuli, and A. Dainty, "Sociotechnical systems approach to BIM implementation in a multidisciplinary construction context," Journal of Management in Engineering, vol. 31, no. 1, Article ID A4014005, 2014.

[75] S. Amiya Kumar and A. Pal, "Triangular fuzzy matrices," Iranian Journal of Fuzzy Systems, vol. 4, no. 1, pp. 75-87, 2007.

[76] S. Hendiani and M. Bagherpour, "Development of sustainability index using Z-numbers: a new possibilistic hierarchical model in the context of Z-information," Environment, Development and Sustainability, vol. 22, no. 7, pp. 6077-6109, 2019.

[77] B. Kang, D. Wei, Y. Li, and Y. Deng, "A method of converting Z-number to classical fuzzy number," Journal of Information \& Computational Science, vol. 9, no. 3, pp. 703-709, 2012.

[78] L. A. Zadeh, "A note on Z-numbers," Information Sciences, vol. 181, no. 14, pp. 2923-2932, 2011.

[79] A. Azadeh and R. Kokabi, "Z-number DEA: a new possibilistic DEA in the context of Z-numbers," Advanced Engineering Informatics, vol. 30, no. 3, pp. 604-617, 2016.

[80] J. J. H. Liou, "Building an effective system for carbon reduction management," Journal of Cleaner Production, vol. 103, pp. 353-361, 2015.
[81] D. Dalalah, M. Hayajneh, and F. Batieha, "A fuzzy multicriteria decision making model for supplier selection," Expert Systems with Applications, vol. 38, no. 7, pp. 8384-8391, 2011.

[82] J.-S. Yao and K. Wu, "Ranking fuzzy numbers based on decomposition principle and signed distance," Fuzzy Sets and Systems, vol. 116, no. 2, pp. 275-288, 2000.

[83] A. Baykasoglu and V. Kaplanoglu, "A multi-agent approach to load consolidation in transportation," Advances in Engineering Software, vol. 42, no. 7, pp. 477-490, 2011.

[84] F. Li, W. Wang, S. Dubljevic, F. Khan, J. Xu, and J. Yi, "Analysis on accident-causing factors of urban buried gas pipeline network by combining DEMATEL, ISM and BN methods," Journal of Loss Prevention in the Process Industries, vol. 61, pp. 49-57, 2019.

[85] H. D. Sharma and A. D. Gupta, "The objectives of waste management in India: a futures inquiry," Technological Forecasting and Social Change, vol. 48, no. 3, pp. 285-309, 1995.

[86] J. Sushil, P. K. Ghosh, R. Agrawal, and H. Gupta, "Hierarchical structure for enhancing the innovation in the MSME sector of India," International Journal of Business Excellence, vol. 13, no. 2, pp. 181-199, 2017. 